\title{
Triagem de compostos anti-chagásicos com o Trypanosoma cruzi e leishmanicidas com as espécies Leishmania amazonensis e Leishmania chagasi.
}

Dissertação apresentada ao Programa de PósGraduação do Instituto de Química de São Carlos, da Universidade de São Paulo, para a obtenção do título de Mestre em Ciências.

Área de concentração: Química orgânica e biológicas

Orientador: Prof. Dr. Andrei Leitão

São Carlos 


\section{Exemplar revisado}

O exemplar original encontra-se em acervo reservado na Biblioteca do IQSC-USP. 


\section{DEDICATÓRIA}

Aos meus pais Orlando Iwao Tezuka e Rosa Reiko Tezuka, a minha irmã Érika, pelo belo exemplo de família, por existirem e me apoiarem em todos os momentos. 


\section{AGRADECIMENTOS}

A Deus, pela vida, pela família maravilhosa, pelas amizades verdadeiras ao longo dessa jornada, pelas pessoas que encontrei, pelas realizações.

Aos meus pais, Orlando e Rosa, pelo exemplo de união, de coragem, de determinação, do amor pela vida, pelas palavras de incentivo que me fizeram chegar até aqui, e por todo apoio durante toda a minha vida. A minha irmã Érika Sayuri Tezuka e ao seu marido Fernando Garoso, pela fraternidade, amizade, pelas palavras de carinho, por momentos de alegrias e descontração, e pelo apoio moral. Ao meu namorado Leandro pelos momentos de carinho, de diversão, descontração e pelas palavras de apoio e incentivo a nunca desistir dos meus ideais.

Ao Prof. Dr. Andrei Leitão pela excelente orientação e pelo voto de confiança por ter me aceitado em seu laboratório, e o Prof. Dr. Carlos Alberto Montanari, por conceder o laboratório para o uso de alguns equipamentos.

Aos amigos Karen Cristina dos Santos, Isadora Malavolta, Luis Nagano, Letícia Schwerz que compartilharam comigo momentos de alegria, tristeza, congressos, coffee breaks, passeios, a companhia no almoço, e tiveram muita paciência para me ensinar a trabalhar no LabECel. Aos amigos Marta Saidel, Fabiana Rosini, José Quilles Júnior, Júlio Cesar Sousa por me ajudarem a crescer pessoal e profissionalmente, por todas as reuniões de discussão de artigos, conversas de progressão do projeto, por todas as comemorações de aniversário e passeios.

Ao Grupo NEQUIMED: Elisa Castañeda, Ana Carolina Urbazeck.Adriel Carecho, Fernanda Lenita Ribeiro, Helena Viana, Douglas Mussio, Leandro Antônio Alves Avelar, Igor Prokopczyk, Jean Ribeiro, Geraldo Rodrigues, Karen Rangel, Cristhian Camilo, Érika Meñaca, Daniel Gedder, William Fernandes, pelas jornadas de trabalho, pelos momentos de descontração, congressos e pela cooperação.

Um agradecimento especial para ao Prof. Sérgio de Albuquerque (Faculdade de Farmácia de Ribeirão Preto/USP), Cristina e Miriam pela colaboração científica.

Aos professores da Universidade Paulista (UNIP) de Araraquara do curso de FarmáciaBioquímica, pelo exemplo, didática, momentos de descontração e orientação na vida acadêmica.

Ao Conselho Nacional de Desenvolvimento Científico e Tecnológico (CNPQ), Fundação de Amparo à Pesquisa do Estado de São Paulo (FAPESP) pelo suporte financeiro. 
"Sábio é quem não se aflige com o que lhe falta e se alegra com o que possui."

- Demócrito 


\section{RESUMO}

Infecções causadas por tripanossomatídeos causam milhares de mortes anualmente, além de levarem a redução da capacidade produtiva, com elevada morbidade na população acometida. A eficácia terapêutica é limitada na maioria dos casos, sendo o benzonidazol o único fármaco aprovado para uso do tratamento do Trypanosoma cruzi, sendo ativo somente na fase aguda da Doença de Chagas, com grande efeitos colaterais. No caso das leishmanioses, as substâncias de tratamento existentes causam toxicidade renal e cardíaca, além de induzirem a resistência e apresentarem eficácia insuficiente. Observando todo o contexto torna-se necessário a busca por novas substâncias que sejam mais eficazes e menos tóxicas. Assim, o trabalho representa uma contribuição para a busca de novas moléculas bioativas para o tratamento da doença de Chagas e leishmaniose com a padronização e realização de ensaios celulares usando a forma epimastigota da cepa $Y$ do $T$. cruzi e promastigota para Leishmania chagasi e L. amazonensis. A padronização do método colorimétrico de MTT foi realizada a partir da comparação com o método tradicional de contagem por microscopia usando câmara de Neubauer, seguido do estudo de viabilidade por citometria de fluxo, como método confirmatório e, finalmente, a padronização do ensaio de ciclo celular usando os fármacos de referência benzonidazol ( $T$. cruzi) e anfotericina B (Leishmania spp.). Os compostos testados neste estudo são provenientes de classes distintas de inibidores de alvos macromoleculares (cisteíno proteases, DHODH, GAPDH, quinases) e foram planejados e/ou selecionados pelo Grupo de Química Medicinal (NEQUIMED). Dentre todas as substâncias, inibidores de quinases apresentaram maior potencial para estudos subsequentes, sendo o $T$. cruzi o parasito mais sensível, onde um grande número de substâncias apresentou atividade nos estudos de triagem. Para uma delas (Neq0474) foi realizado o ensaio de dose-resposta, com EC $50=53 \mu \mathrm{mol} / \mathrm{L}$. L. chagasi apresentou a maior resistência dentre todos os parasitos estudados neste trabalho, enquanto que L. amazonensis foi sensível para Neq0438. Algumas substâncias estudadas apresentaram potencial para estudos mais aprofundados visando identificar novas alternativas terapêuticas para estas doenças parasitárias. 


\begin{abstract}
Infections caused by trypanosomatides lead to thousands of deaths annually, along with the reduction of the quality of life and working capability, with high morbidity to the patients. The therapy efficacy is limited in most cases, being benznidazole the only approved drug in Brazil, which works only in the acute phase of the Chagas Disease with severe collateral effects. For leishmaniasis, drugs cause renal and cardiac toxicity and trigger resistance. In this context, novel efficacious and safe substances are necessary to improve the current therapeutic strategies, which was the goal of this project by means of cell-based screenings. The first step was the standardization of the MTT colorimetric assay for the epimastigote form of the $Y$ strain of Trypanosoma cruzi and promastigote form of Leishmania chagasi and Leishmania amazonensis. This was achieved by comparing the results with the standard counting using the Neubauer chamber. The use flow cytometry for the determination of cell viability and the perturbation of the cell cycle were also standardized using the reference drugs benznidazole ( $T$. cruzi) and amphotericin B (Leishmania spp.). New compounds tested in this project were designed or selected based on different macromolecular targets (cysteine proteases, DHODH, GAPDH, kinases) by the Medicinal Chemistry Group (NEQUIMED). Among them, many kinase inhibitors promoted the most dramatic results for $T$. cruzi, reducing the cell viability of this parasite. One of them (Neq0474) was subjected for a follow-up dose-response assay, with $\mathrm{EC}_{50}=53 \mu \mathrm{mol} / \mathrm{L}$. L. chagasi was the most resistant parasite in this work, whereas L. amazonensis was sensitive to Neq0438. Some of these new compounds are of interest for more in-depth studies to these parasitic diseases.
\end{abstract}




\section{LISTA DE FIGURAS}

Figura 1. Distribuição da doença de Chagas pelo mundo.....

Figura 2. Diferentes morfologias do T. cruzi. As formas tripomastigota (A, B), epimastigota $(C, D)$ e amastigota (E, F) são apresentadas na forma de desenho esquemático com as principais estruturas e também por meio de microscopia de campo claro. ............................... 17

Figura 3. Ciclo biológico do T. cruzi ...................................................................................... 20

Figura 4. Representação estrutural dos fármacos disponíveis para tratamento da doença de Chagas. 21

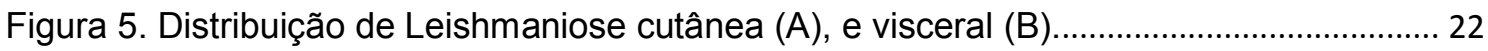

Figura 6. Diferentes morfologias da leishmaniose: $(A)$ amastigotas; $(B)$ promastigotas. ....... 25

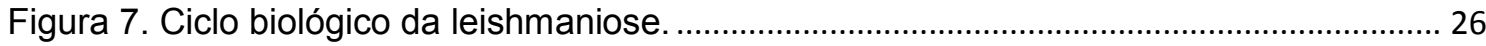

Figura 8. Representação estrutural dos antimoniais usados como terapias de primeira

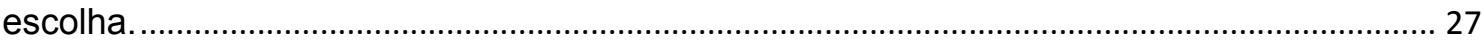

Figura 9. Representação estrutural dos fármacos de segunda escolha. .................................. 28

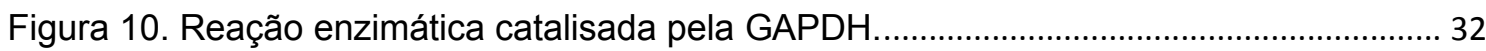

Figura 11. Representação esquemática do ciclo celular........................................................... 33

Figura 12. Curva de crescimento da forma epimastigota do T. cruzi (cepa Y) estabelecida pela contagem na câmara de Neubauer. .................................................................................. 48

Figura 13. Curva de crescimento da forma promastigota de $L$ amazonensis com duas concentrações iniciais de $1 \times 10^{6}$ células $/ \mathrm{mL}$ e $1 \times 10^{5}$ células $/ \mathrm{mL}$............................................... 49

Figura 14. Curva de crescimento da forma promastigota de $L$. chagasi com duas concentrações iniciais de $1 \times 10^{6}$ células $/ \mathrm{mL}$ e $1 \times 10^{5}$ células $/ \mathrm{mL}$

Figura 15. Solubilização dos cristais de formazan a partir de diferentes proporções de agente solubilizante e DMSO e tempos de incubação para T. cruzi.

Figura 16. Ensaio colorimétrico do tipo de agente solubilizante e do tempo de incubação para T. cruzi. 53

Figura 17. Regressão linear demonstrando a correlação existente entre o método colorimétrico de MTT e a concentração dos parasitos por contagem na câmara de Neubauer para forma epimastigota da cepa $Y$ do $T$. cruzi....................................................................... 54 Figura 18. Viabilidade do T. cruzi após a incubação com o extran durante a) 4 h e b) 24 h. 55 Figura 19. Triagem usando a forma epimastigota da cepa $Y$ do $T$. cruzi com incubação do benzonidazol por 5 dias.

Figura 20. Análise morfológica da forma epimastigota, cepa Y do T. cruzi, com incubação do benzonidazol no quinto dia de incubação. 59

Figura 21. Solubilização dos cristais de formazan a partir de diferentes proporções de agente solubilizante e DMSO para L. chagasi. 60

Figura 22. Regressão linear demonstrando a correlação existente entre o método colorimétrico de MTT e a concentração dos parasitos por contagem na câmara de Neubauer para forma promastigota de L. chagasi.

Figura 23. Ensaio colorimétrico para observar o efeito do agente solubilizante em $L$. chagasi

62

Figura 24. Ensaio de concentração-resposta com a anfotericina B para L. chagasi usando análise colorimétrica por MTT e quantificação por microscopia em câmara de Neubauer.... 63 
Figura 25. Solubilização dos cristais de formazan a partir de diferentes proporções de agente solubilizante e DMSO e tempo de incubação para $L$. amazonensis............................. 65

Figura 26. Ensaio colorimétrico para observar o efeito do agente solubilizante em $L$. amazonensis. 66

Figura 27. Regressão linear demonstrando a correlação existente entre o método colorimétrico de MTT e a concentração dos parasitos por contagem na câmara de Neubauer para forma promastigota de $L$. amazonensis.

Figura 28. Ensaio de concentração-resposta com a anfotericina B para L. amazonensis usando análise colorimétrica por MTT e quantificação por microscopia em câmara de Neubauer. 68

Figura 29. Triagem de compostos inibidores de cisteíno proteases a $100 \mu \mathrm{M}$ na forma epimastigota do T. cruzi. 70

Figura 30. Relação estrutura-atividade para Neq0565 e Neq0566.

Figura 31. Triagem de compostos inibidores de cisteíno proteases a $100 \mu \mathrm{M}$ na forma promastigota da L. chagasi.

Figura 32. Triagem de compostos inibidores de cisteíno proteases a $100 \mu \mathrm{M}$ na forma promastigota da L. amazonensis

Figura 33. Triagem de compostos inibidores de DHODH nos tripanossomatídeos............... 74

Figura 34. Triagem de compostos inibidores da GAPDH nos tripanossomatídeos, através do método colorimétrico.

Figura 35. Triagem de compostos inibidores de quinases na forma epimastigota da cepa $Y$ do T. cruzi com o método colorimétrico (MTT).

Figura 36. Triagem de compostos inibidores de quinases na forma epimastigota da cepa $Y$ do $T$. cruzi usando a contagem com câmara de Neubauer.

Figura 37. Concentração-resposta com Neq0474 na forma epimastigota da cepa $Y$ do $T$. cruzi após 5 dias de incubação.

Figura 38. Triagem de compostos inibidores de quinases em L. chagasi pelo método colorimétrico (MTT).

Figura 39. Triagem de compostos inibidores de quinases em $L$. amazonensis pelo método colorimétrico (MTT).

Figura 40. Curvas concentração-resposta dos fármacos de referência benzonidazol ( $T$. cruzi) e anfotericina B ( $L$. chagasi e $L$. amazonensis) determinada pelo método de citometria de fluxo.

Figura 41. Ciclo celular do T. cruzi sem tratamento (A) e com incubação por $48 \mathrm{~h}$ de $250 \mu \mathrm{M}$ de benzonidazol (B).

Figura 42. Ciclo celular da L. chagasi sem tratamento (A) e com incubação por $6 \mathrm{~h}$ de 500 $\mu \mathrm{M}(\mathrm{B})$ e $200 \mu \mathrm{M}(\mathrm{C})$ de anfotericina $\mathrm{B}$

Figura 43. Ciclo celular da L. chagasi sem tratamento $(A)$ e com incubação por 12 h de 500 $\mu \mathrm{M}(\mathrm{B})$ e $200 \mu \mathrm{M}(\mathrm{C})$ de anfotericina B. 86

Figura 44. Ciclo celular da $L$. amazonensis sem tratamento (A) e com incubação por $6 \mathrm{~h}$ de $500 \mu \mathrm{M}(\mathrm{B})$ e $200 \mu \mathrm{M}(\mathrm{C})$ de anfotericina B

Figura 45. Ciclo celular da L. amazonensis sem tratamento $(A)$ e com incubação por $12 \mathrm{~h}$ de $500 \mu \mathrm{M}(\mathrm{B})$ e $200 \mu \mathrm{M}(\mathrm{C})$ de anfotericina $\mathrm{B}$ 


\section{LISTA DE TABELAS}

Tabela 1. Parâmetros estatísticos das regressões lineares da correlação entre o método colorimétrico (MTT) e a contagem na câmara de Neubauer para o T. cruzi.

Tabela 2. Parâmetros estatísticos das curvas concentração-resposta do detergente extran.

Tabela 3. Parâmetros estatísticos das triagens usando a forma epimastigota da cepa $Y$ do $T$. cruzi com incubação do benzonidazol por 5 dias.

Tabela 4. Parâmetros estatísticos das regressões lineares da correlação entre o método colorimétrico (MTT) e a contagem na câmara de Neubauer para a L. chagasi.

Tabela 5.Parâmetros estatísticos da curvas concentração-resposta da anfotericina B após incubação com a L. chagasi.

Tabela 6. Parâmetros estatísticos das regressões lineares da correlação entre o método colorimétrico (MTT) e a contagem na câmara de Neubauer para a Leishmania amazonensis.

Tabela 7. Parâmetros estatísticos da anfotericina B para L. amazonensis 


\section{Siglas e abreviaturas}

CPA Cisteíno protease tipo A

CPB Cisteíno protease tipo B

CPC Cisteíno protease tipo C

DHODH Diidroorotato Desidrogenase

DMSO Dimetilsulfóxido

GAPDH Gliceraldeído3-Fosfato Desidrogenase

kDNA DNA dos Cinetoplastos

L. amazonensis Leishmania amazonensis

L. chagasi Leishmania chagasi

LIT Meio de cultura com infuso de fígado e triptose para crescimento de T. cruzi

MTT Brometo azul de tetrazólio/ 3-(4,5-dimetiltiazol-2-il) -2,5-difeniltetrazolium brometo

PMS Metasulfato de fenazina

PBS Tampão Fosfato Salino

T. cruzi Trypanossoma cruzi 


\section{Sumário}

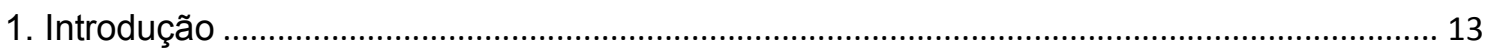

1.1. Doenças Tropicais Negligenciadas ............................................................................... 13

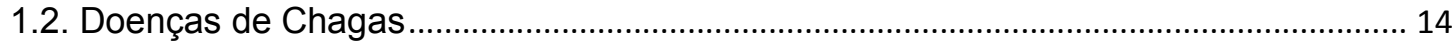

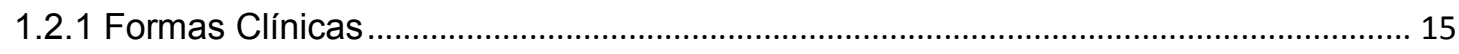

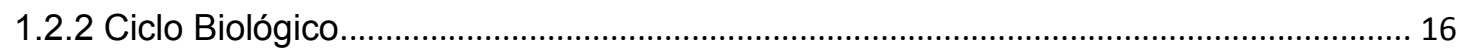

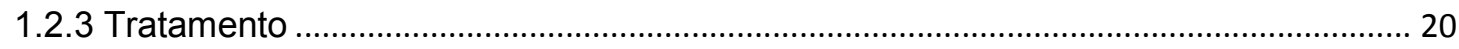

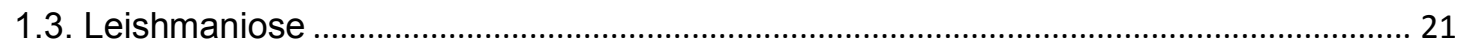

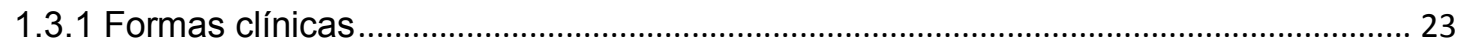

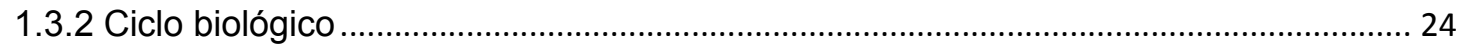

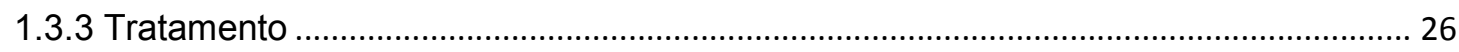

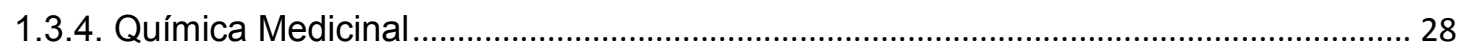

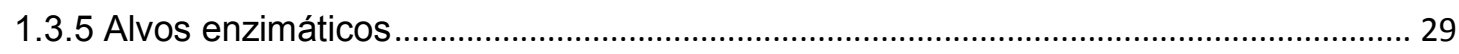

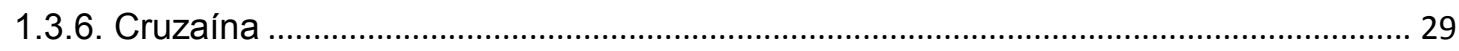

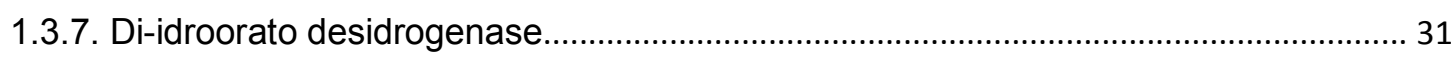

1.3.8. Giceraldeído-3-fosfato desidrogenase (GAPDH) …................................................ 32

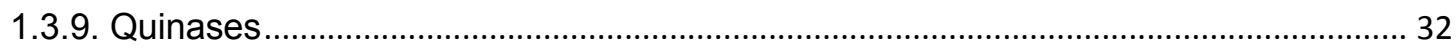

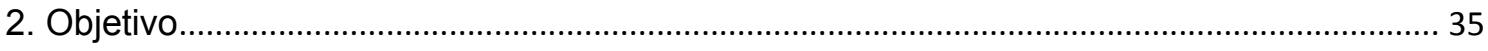

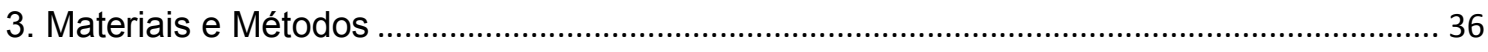

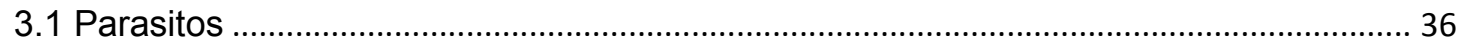

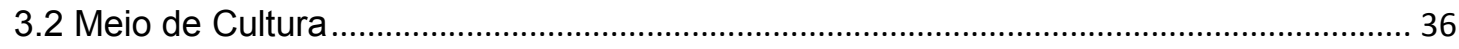

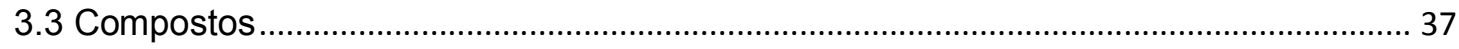

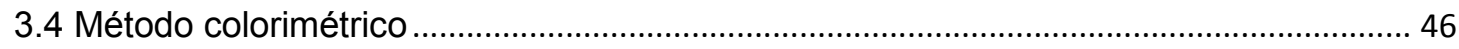

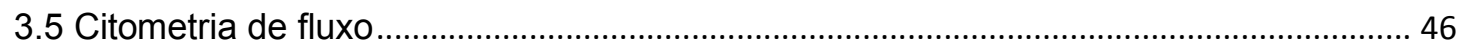

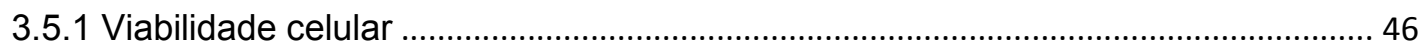

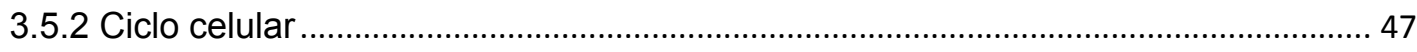

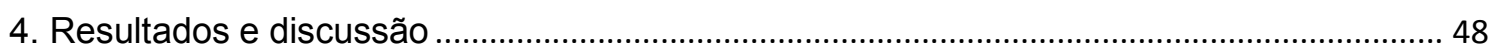

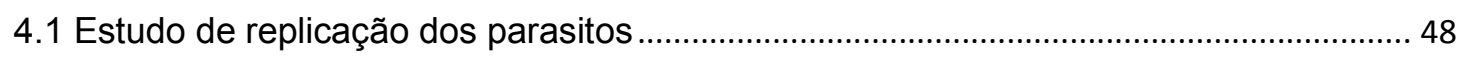

4.2 Padronização do método colorimétrico ............................................................................ 50

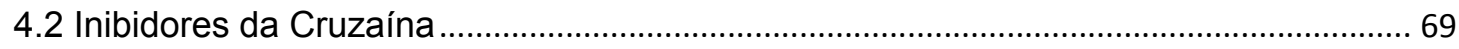

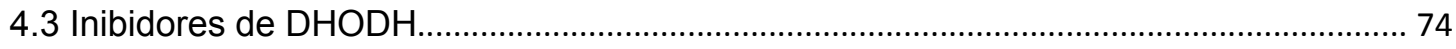

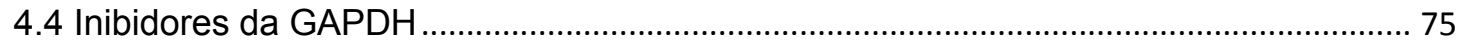

4.5 Substâncias com potencial inibição de quinases ........................................................... 76 
4.6 Determinação da viabilidade celular por citometria de fluxo para os fármacos de

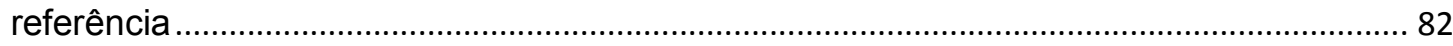

4.7 Análise das alterações do ciclo celular para os fármacos de referência .......................... 84

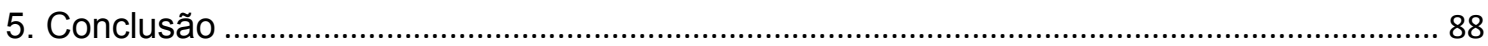

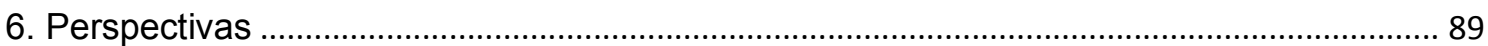

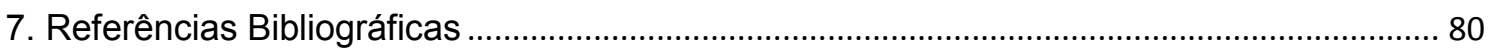




\section{Introdução}

\subsection{Doenças Tropicais Negligenciadas}

Essa designação se refere a doenças infecciosas que apresentam maior incidência em regiões quentes e úmidas e são consequências de subdesenvolvimento social, com prevalência elevada em países pobres. Algumas dessas doenças são causadas por protozoários (doença de Chagas, doença do sono, leishmaniose e malária), helmintos (filaríase, ascaridíase, oncocercose, esquistossomose), bactérias (tuberculose, lepra, tracoma) e vírus (dengue e febre amarela). ${ }^{1-3}$

A maioria dessas doenças causa altos índices de morbidade e mortalidade afetando milhões de pessoas no mundo incluindo homens, mulheres e crianças. Os tratamentos disponíveis são restritos e ineficazes, com quadro agravado pela constante presença de microrganismos resistentes. ${ }^{1,2}$

As doenças tropicais são consideradas negligenciadas, principalmente porque elas não oferecem retorno financeiro suficiente para a indústria farmacêutica, com que tem limitado o desenvolvimento de novas terapias mais eficazes. $O$ direito exclusivo de comercialização, conhecido como patente, é obtido a partir da aprovação de um fármaco, que permite a fabricação exclusiva por um período de 20 anos a partir da data do depósito da patente. Na prática, devido ao tempo necessário para desenvolver uma novo fármaco para o mercado, a exclusividade de comercialização é de cerca de 12-14 anos. Apesar de uma necessidade cada vez maior de medicamentos eficazes e seguros a preços acessíveis para o tratamento destas doenças, a indústria argumenta que uma ampla proteção desses direitos é essencial para garantir a rentabilidade, tão necessária para reinvestir em pesquisa de novos fármacos. ${ }^{1}$

As patentes também se destinam a beneficiar a comunidade, ao incentivar a inovação e assegurar uma fonte acessível de fármaco. No entanto, como essas doenças acometem regiões menos desenvolvidas $e$, analisando o alto custo de investimento para desenvolvimento de novos fármacos com retorno financeiro inadequado, é quase inexistente a pesquisa e desenvolvimento (P\&D) nessa área. Estima-se que apenas $10 \%$ em é investido P\&D para essas doenças onde $90 \%$ da população encontram-se em área de risco. ${ }^{1-4}$ 
Para reverter esse panorama, parcerias envolvendo uma tríade governouniversidade-empresa vem sendo estabelecidas, como por exemplo Iniciativas de Medicamentos para Doenças Negligenciadas (DNDi - Drugs for Neglected Diseases Initiative). A partir dessas parcerias, tem-se desenvolvido medicamentos para doenças tropicais como, por exemplo, praziquantel (Bayer) para esquistossomose, Ivermectina (Merck) para oncocercose e miltefosina (Zentaris) para leishmaniose. 3,4 Desta forma, o uso do conhecimento científico presente na academia tem levado a viabilizar diversos programas de descoberta de novas substâncias bioativas com interesse farmacológico, gerando uma nova configuração de pesquisa e desenvolvimento no âmbito universitário.

\subsection{Doenças de Chagas}

Em 1909 o médico brasileiro Carlos Chagas descreveu a chamada tripanossomíase americana, onde relatou o ciclo de transmissão e as manifestações clínicas do primeiro caso evidenciado pelo parasito protozoário hemoflagelado Trypanosoma cruzi ( $T$. cruzi), pertencente a ordem kinetoplastida. Esta patologia é distribuída principalmente nas Américas, onde já foi relatada em 22 países ${ }^{5}$, desde o norte do México até o sul da Argentina e do Chile. De acordo com a Organização Mundial de Saúde (OMS) a doença afeta entre 6-8 milhões de pessoas na América Latina, onde 50.000 morrem por $a^{6} o^{6}$ e 100 milhões estão sob risco de adquirir a infecção em todo o mundo. Embora estes números sejam bem consideráveis, a doença de Chagas é considerada uma doença negligenciada, com pouco investimento de empresas farmacêuticas na área, o que culmina na falta de um tratamento eficaz mesmo após 100 anos de sua descrição (Figura1). ${ }^{7-14}$

A principal forma de transmissão da doença para os humanos ocorre pela picada do inseto vetor infectado pelo parasito, comumente chamado "Barbeiro", o qual pertence a ordem Hemíptera, família Reduviidae e subfamília Triatominae. Essa família possui mais de 150 espécies, sendo as mais importantes relacionadas com a doença Triatoma infestans, T. dimidiata, T. brasiliensis, T. sordida, Rhodnius prolixus e Panstrongylus megistus. Além disso, mais de 100 espécies de mamíferos selvagens mantêm o ciclo de infecção do $T$. cruzi na natureza. ${ }^{9-11,15}$ 
A contaminação se dá pelo contato das fezes do inseto com os olhos, a boca, mucosas e lesões na pele. Entretanto, pode também ser transmitida por transfusão sanguínea e de órgãos, infecção de mãe para filho, alimentos contaminados e acidentes de laboratório, por isso a doença alastrou-se para áreas onde a patologia não era relatada anteriormente. Devido à crescente emigração de pessoas infectadas para áreas não endêmicas foram identificados casos em países como os Estados Unidos (mais de 300.000 infectados), Canadá (5.000), Austrália (1.500), Japão (3.000), e no continente Europeu (mais de 80.000). ${ }^{15}$

Figura 1. Distribuição da doença de Chagas pelo mundo

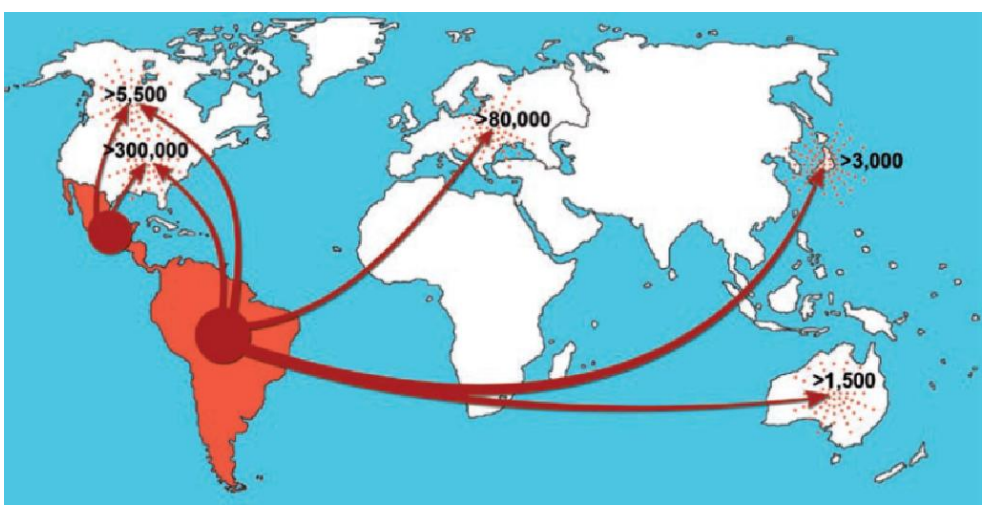

Fonte: Coura, J. R.; Vinas, P. A. Chagas disease: a new worldwide challenge. Nature, v. 465, n. n7301_supp, p. S6-S7, 2010

\subsubsection{Formas Clínicas}

A doença apresenta duas fases clínicas:

(i) aguda: de curta duração, caracterizada por uma lesão inflamatória no local de entrada do parasita no organismo, denominada de chagoma de inoculação e o sinal de Romaña (edema bipalpebral unilateral nem sempre presente) e pode estar associado à linfoadenopatia focal ${ }^{16}$. Outras manifestações eventualmente associadas são hepatoesplenomegalia suave, um quadro febril rápido e inexplicável e, raramente, miocardite intensa, vômito, diarreia, náuseas. No entanto, na maioria das vezes, a infecção aguda é assintomática. Ela apresenta muitos parasitos circulantes, e posteriormente progride para a fase crônica. O período de incubação da fase aguda varia de 4 a 15 dias para a transmissão vetorial (inseto triatomíneo) e 22 dias para a contaminação por via oral. ${ }^{16-18}$ As manifestações clínicas de pacientes com a doença 
na fase aguda são autolimitadas, excetuando os pacientes que apresentam meningoencefalite ou miocardite, que são manifestações graves e acometem principalmente crianças e pacientes imunossuprimidos. Sintomática ou não, a fase aguda a doença evolui para a fase crônica.

(ii) crônica: ocorre décadas após a infecção e apresenta poucos parasitos circulantes devido ao controle por componentes celulares humorais e da resposta imune adquirida pela destruição das formas circulantes, podendo ser de forma cardíaca, digestiva ou mista. No caso da infecção se localizar no coração, ocorre hipertrofia do coração e miocardite crônica progressiva, podendo manifestar através de arritmias e insuficiência cardíaca congestiva. A principal causa da morte na doença de Chagas é devido à forma cardíaca pela ocorrência de morte súbita. Este curso é fatal, já que o tratamento é sintomático e a única opção de terapêutica para os pacientes que evoluem para uma fase crônica cardíaca descompensada é o transplante cardíaco. No entanto, este apresenta limitações como o alto custo e a necessidade do uso de fármacos imunossupressores que podem reativar a parasitemia persistente na fase crônica da infecção. A forma digestiva apresenta alterações hipertróficas no esôfago e no cólon intestinal, que levam a problemas de disfagia e constipação intestinal. E a forma mista é caracterizada pelo concomitante comprometimento do coração e da área digestiva. ${ }^{19,20}$

\subsubsection{Ciclo Biológico}

O Trypanosoma cruzi é caracterizado pela existência de um único flagelo e de um cinetoplasto, organela próximo ao flagelo, e que apresenta DNA mitocondrial (kDNA, representando $30 \%$ do total), por isso este protozoário pertence à ordem Kinetoplastida e família Trypanosomatidae. ${ }^{21}$

Durante o ciclo de vida heteróxeno do parasito (que compreende um vetor inseto - e um hospedeiro vertebrado) três morfologias distintas são identificadas. No hospedeiro invertebrado são observadas as formas epimastigotas e tripomastigotas metacíclicos. Já no hospedeiro mamífero ocorrem as formas tripomastigotas sanguíneas e amastigotas intracelulares. 9,22,23

A forma tripomastigota (Figura 2A e B) possui aproximadamente $25 \mu \mathrm{m}$ de comprimento, apresenta citossomo longo e achatado, com o cinetoplasto e o bolso 
flagelar deslocado para a região central próximo ao núcleo; e o flagelo percorre toda extensão do corpo aderido por sua longa membrana ondulante. A forma epimastigota (Figura 2C e D) pode variar no tamanho de 20 a $40 \mu \mathrm{m}$ e possui membrana ondulante curta e flagelo livre e bem desenvolvido. ${ }^{24}$

A forma amastigota (Figura 2 E e F) geralmente apresenta contorno circular ovoide ou fusiforme e tem tamanho aproximado de $5 \mu \mathrm{m}$ e corpo achatado com pouco citoplasma, núcleo grande, redondo e excêntrico, cinetoplasto bem visível e ausência de membrana ondulante. ${ }^{18,19,25}$

Figura 2. Diferentes morfologias do T. cruzi. As formas tripomastigota (A, B), epimastigota (C, D) e amastigota (E, F) são apresentadas na forma de desenho esquemático com as principais estruturas e também por meio de microscopia de campo claro.

A

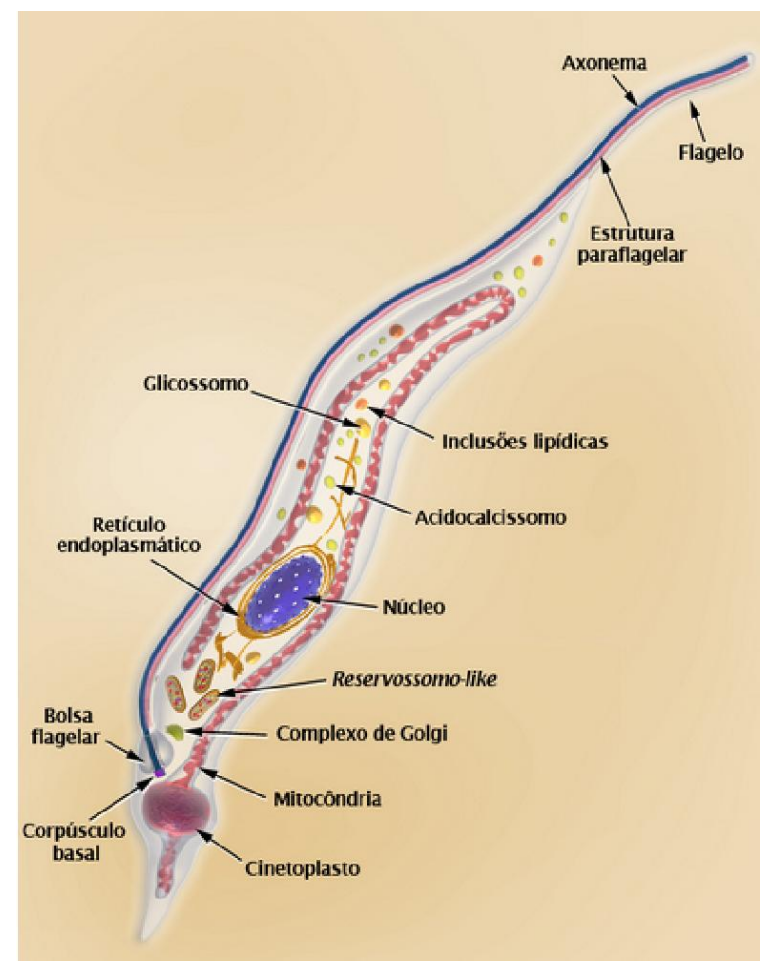

B

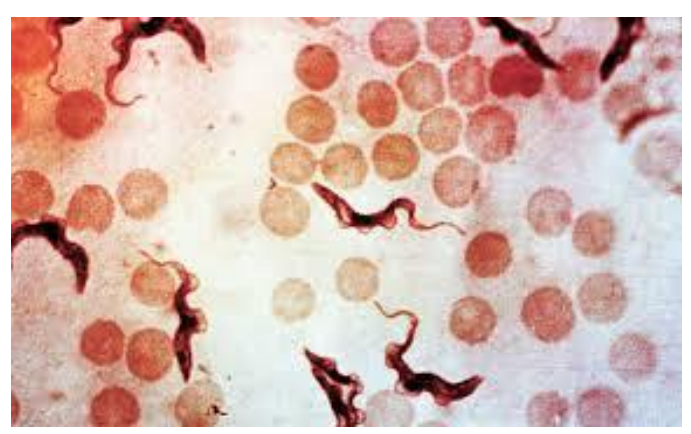


C

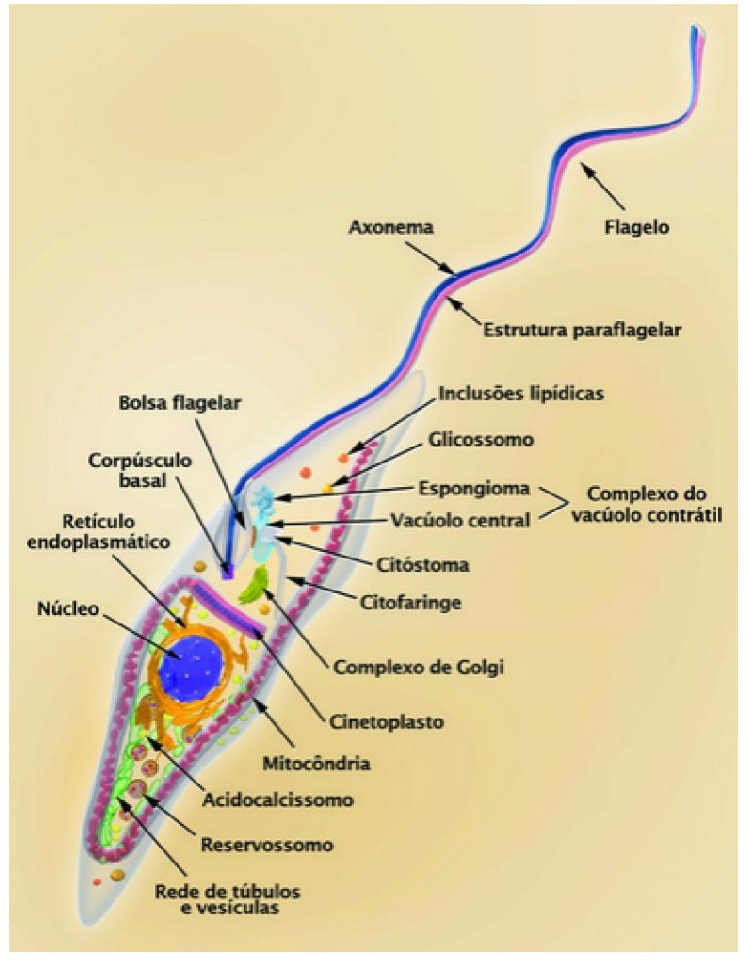

E

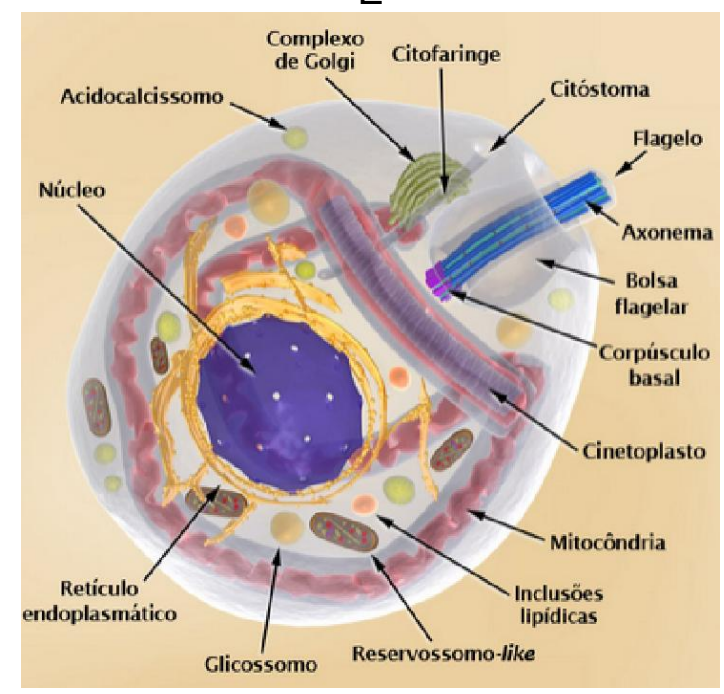

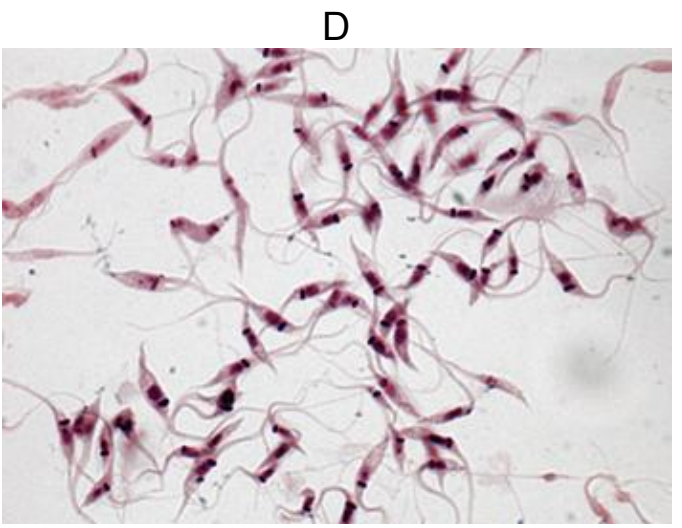

Fonte: A, C e E. Teixeira, D.E.; Benchimol, M.; Crepaldi, P.H.; Souza, W. Atlas didático. Ciclo de vida do T. cruzi, 2013. Disponível em: http://www.open.edu/openlearnworks/course/view.php?id=1292. Acessado em 07 de Maio de 2015. B. http://www.jornalufgonline.ufg.br/pages/44396

D. http://www.fiocruz.br/chagas/cgi/cgilua.exe/sys/start.htm?sid=13c

F. http://www.geocities.ws/carolparada/parasitologia/atlas05trypasomacruzi.htm 
No hospedeiro vertebrado, o ciclo de vida do $T$. cruzi tem início quando um triatomíneo infectado pica o homem, e com isso ele elimina nas fezes e na urina o flagelado tripomastigota metacíclico antes de terminar sua alimentação. Este encontra uma porta de entrada no sistema circulatório humano pela lesão ocasionada pela picada, ultrapassa o sistema imune, invade células epiteliais, macrófagos e fibroblastos e, durante a invasão celular, há a formação de um vacúolo endocítico denominado vacúolo parasitóforo. Dentro das células sua morfologia altera para amastigota e começa a multiplicar-se por divisão binária simples. Quando a célula já está com muitas amastigotas, eles se diferenciam em tripomastigotas sanguíneos; a célula se rompe, levando-os a cair na corrente sanguínea para invadir novas células, tecidos e órgãos. A forma sanguínea pode ser destruída por algum mecanismo de defesa do hospedeiro ou pode ser ingerida por um triatomíneo e cumprir seu ciclo extracelular (Figura 3). 17,20

O hospedeiro invertebrado se infecta através da ingestão de sangue de animais infectados. Os tripomastigotas sanguíneos se transformam em epimastigotas no estômago do vetor e se aderem a mucosa do intestino médio, com intensa replicação. Posteriormente os epimastigotas migram para o intestino posterior atingindo o reto $\mathrm{e}$ transformando-se em tripomastigota metacíclico, os quais são eliminados pelas fezes no próximo repasto sanguíneo. $17,18,20,21$ 
Figura 3. Ciclo biológico do T. cruzi

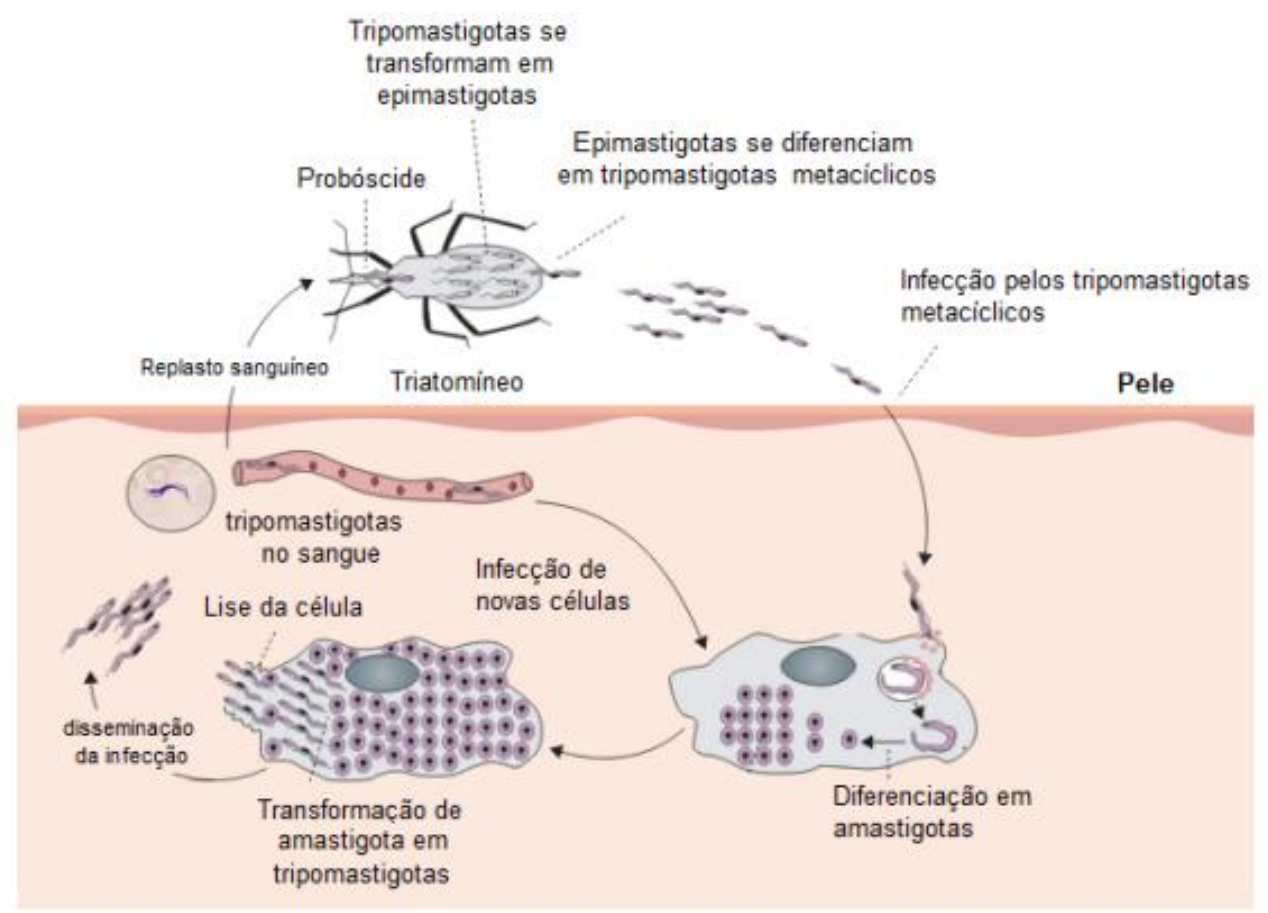

Fonte: Rassi Jr, A.; Rassi, A.; Marin-Neto, J. A. Chagas Disease. The Lancet, v.375, n.9723, p.1388-1402.

\subsubsection{Tratamento}

Os fármacos utilizados no tratamento desta doença foram aprovados na década de 1970: nifurtimox (4 -(5-nitrofurfurilindenamino)-3-metiltiomorfolina 1,1dióxido, produzido pela Bayer) e benzonidazol (N-benzil-2-(2-nitro-1H-imidazol-1-il) acetamida, produzido pela Roche). ${ }^{26}$ Esses fármacos são nitro heteroaromáticos (Figura 4) e apresentam eficácia somente na fase aguda, além terem restrições de administração por apresentarem alta toxicidade.

O nifurtimox não é mais usado no país devido aos efeitos colaterais. Os efeitos mais observados para esses fármacos são vômito, polineuropatia periférica, perda de peso, dermopatias alérgicas (por causa do dano ao tecido hospedeiro) e anorexia. 
Figura 4. Representação estrutural dos fármacos disponíveis para tratamento da doença de Chagas.

Benzonidazol<smiles>O=C(Cn1ccnc1[N+](=O)[O-])NCc1ccccc1</smiles>

Nifurtimox

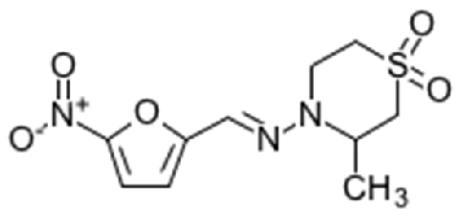

Para ambos os fármacos, o mecanismo de ação proposto ocorre a partir da redução do grupo nitro a uma amina pela ação de nitroredutases, com a formação de vários radicais livres intermediários e metabólitos eletrofílicos. ${ }^{27,28}$

Até o momento não existe nenhuma vacina e nenhum fármaco profilático para o controle da doença. ${ }^{10}$ Além disso, os fármacos existentes não são eficazes para a forma crônica da tripanossomíase, sendo necessário estudar novas moléculas bioativas para esta patologia. ${ }^{29,30}$

\subsection{Leishmaniose}

A leishmania é um gênero de protozoários pertencente à família Tripanossomatidae, ordem kinetoplastida, que é o agente etiológico da leishmaniose.

Essa doença é prevalente em países pobres entendendo-se ao continente Americano, Africano e Asiático. A patologia era comum em áreas rurais, porém com o aumento de áreas urbanas ela se alastrou e, atualmente, afeta 12 milhões de pessoas em 88 países tropicais e subtropicais, ${ }^{31}$ com 2 milhões de novos casos anuais, além de 350 milhões de pessoas vivendo em área de risco e 20.000-40.000 mortes ao ano. ${ }^{32-35}$

A principal transmissão é ocasionada por um vetor flebótomo, pertencente a ordem Díptera, família Psychodidae, subfamília Phlebotominae, gênero Lutzomyia, conhecidos popularmente, dependendo da localização geográfica, como mosquito palha, tatuquira, birigui, entre outros. A infecção ocorre usualmente por meio do inseto (80-90\% dos casos), mas também pode ocorrer por transfusão de sangue $(5-20 \%)$ e por via congênita $(0,5 \%-0,8 \%) \cdot{ }^{36}$ 
Mais de $90 \%$ dos casos de leishmaniose visceral está concentrado na Índia, Blangadesh, Nepal, Sudão e Brasil ${ }^{32}$. 90\% de leishmaniose cutânea ocorre no Iran, Afeganistão, Arábia Saudita, Síria, Peru e Brasil; enquanto que $90 \%$ dos casos de leishmaniose mucocutânea está presente no Brasil, Peru e Bolívia ${ }^{37,38}$.

Figura 5. Distribuição de Leishmaniose cutânea (A), e visceral (B).
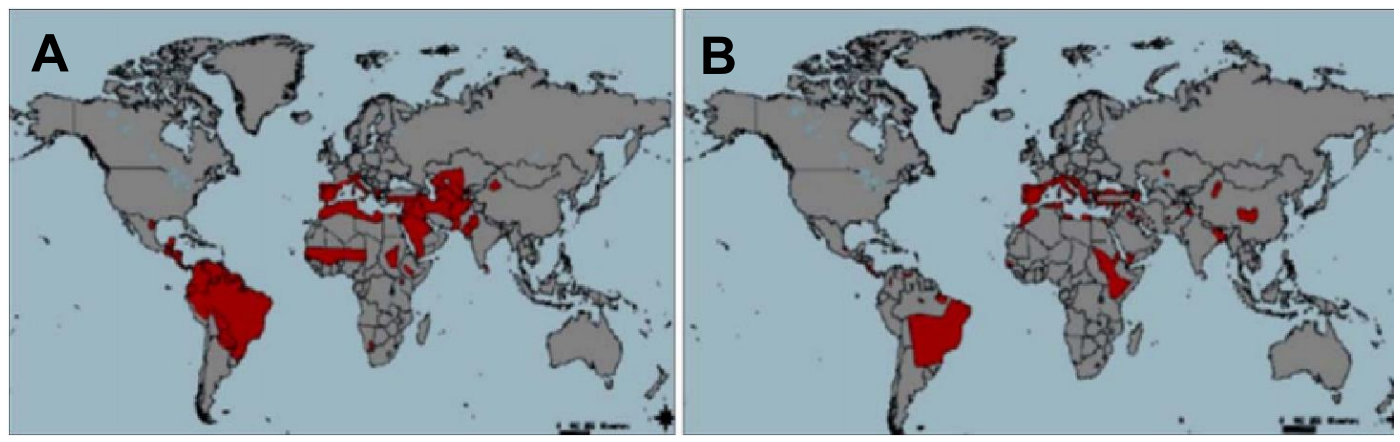

Fonte: Santos, D.O.; Coutinho, C.E.R.; Madeira, M.F.; Bottino, C.G.; et al. Leishmaniasis treatment- a challenge that remains: a review. Parasitol Research, v. 103, 2008, p. 1-10. (WHO, 2010)

Nas Américas, a leishmaniose cutânea é frequentemente causada pelas espécies L. brasiliensis, L. amazonensis, L. mexicana, L. peruviana, L panamensise $L$. guyanensis. A espécie mais devastadora que causa a forma mucocutânea é a $L$. brasiliensis. ${ }^{33,39}$

Na África, Ásia e Europa a leishmaniose visceral é causada pelas espécies $L$. donovani ou L. infantum (esta é sinônima a L. chagasi nas Américas, sendo reportada como L. infantum chagasi). ${ }^{33,39,40}$ Infelizmente não existe tratamento efetivo, especialmente para a forma visceral, que leva ao óbito, pois a quimioterapia existente é ineficiente.

Neste estudo, utilizou-se L. amazonensis, que é uma espécie frequente nas florestas da Amazônia (seus hospedeiros naturais são os marsupiais e roedores silvestres), além da L. chagasi, que são os principais agentes etiológicos da leishmaniose no Brasil. ${ }^{40}$ 


\subsubsection{Formas clínicas}

As leishmanioses representam um conjunto de enfermidades diferentes entre si, que pode compreender pele, mucosas e vísceras, dependendo da espécie do parasita (já foram identificadas 21$)^{41} \mathrm{e}$ da resposta imune do hospedeiro.

A forma clínica cutânea é a mais frequente, provoca ulcerações na pele que tendem a cicatrização, causadas pelas espécies Leishmania tropica, L. major, $L$. aethiopica, L. mexicana, L. amazonensis, L. panamensis, L. guyanensis, L. peruviana ou L. braziliensis. Conhecida como ferida brava ou úlcera de Bauru, é caracterizada pela presença de lesões cutâneas de vários tipos, geralmente progredindo para uma úlcera crônica que pode disseminar progressivamente causando metástases. ${ }^{42,43}$

O período de incubação varia de duas semanas a dois meses, após esse período aparece a lesão inicial, que na maioria das vezes é única, cresce lentamente até tornar-se ulcerada. As lesões podem variar no tamanho, medindo vários centímetros, com características comuns como contornos regulares, inodoras, pouco exsudativas e fundo granuloso. Alguns indivíduos apresentam cura precoce da lesão, às vezes sem atendimento médico. Outros permanecem meses com a lesão em atividade e o processo de cicatrização mostra-se lento. Este fenômeno pode ser explicado pelo estabelecimento rápido ou tardio de uma resposta imune específica eficiente na eliminação do parasito. ${ }^{42,44}$

A forma cutânea difusa é causada pelas $L$. aethiopica ou $L$. amazonensis. As lesões são papulosas ou nodulares deformantes, não observando ulceração. Estas se distribuem amplamente na superfície corporal, pois na ausência de uma resposta imune celular efetiva contra o parasito, que se multiplica sem controle, aumentando o número de lesões e expandindo sua distribuição pelo corpo. Esta forma de leishmaniose se apresenta raramente, a cura não é espontânea, de difícil tratamento e apresenta recaída após o tratamento. ${ }^{42-44}$

Os casos de leishmaniose cutâneo-difusa são originados de infecção adquirida na infância, o que sugere um papel da imaturidade do sistema imune no desenvolvimento desta forma clínica. O parasito passa a ser encontrado em grande quantidade nas lesões e o processo inflamatório mostra-se desorganizado, não sendo capaz de controlar a infecção. A resposta terapêutica é pobre ou ausente. ${ }^{42,45}$ 
A leishmaniose mucocutânea caracteriza-se por lesões tardias, que surgem geralmente meses ou anos após a cura de uma lesão cutânea, destruindo preferencialmente mucosas do nariz, boca e garganta, que se estende progressivamente aos tecidos moles, com inflamação e ulceração. Posteriormente a lesão se aprofunda, e nestas lesões se encontram poucos parasitos. ${ }^{42,46} \mathrm{O}$ agente etiológico principal é a $L$. braziliensis e se caracteriza imunologicamente pelo exagero das respostas celulares anti-leishmania e pela escassez de parasitos. Portanto a resposta exacerbada promove a destruição de tecidos onde houver depósito de partículas antigênicas. Na maioria dos casos, a leishmaniose mucocutânea resulta da leishmaniose cutânea com evolução crônica e com aparente cura sem tratamento ou com tratamento inadequado. $37,42,43,46$

A leishmaniose visceral, também chamada Kalazar, febre negra ou esplenomegalia tropical, é uma doença crônica e endêmica em várias regiões do mundo. Ela especialmente crianças e pessoas imunodeprimidas e é causada pela $L$. donovani e L. infantum (L. chagasi na América Latina). O período de incubação varia de dois a oito meses. $O$ início da doença é insidioso, com palidez, aparecimento de febre alta, que é o sintoma mais notável pela sua constância, aumento de volume do baço e do fígado, perda de apetite, anemia e hemorragias da gengiva e digestiva, que pode também afetar os vasos linfáticos e a medula óssea. A perda de apetite leva à desnutrição grave, assim a doença tem uma evolução mais rápida e pode levar à morte em algumas semanas. ${ }^{47,48}$

\subsubsection{Ciclo biológico}

O ciclo de vida deste parasito é heteróxeno, pois compreende um vetor e um hospedeiro vertebrado. Duas morfologias distintas são apresentadas, uma flagelada (promastigota), encontrada no tubo digestivo do inseto; e outra aflagelada (amastigota), observada nos tecidos dos hospedeiros vertebrados. ${ }^{33}$

As promastigotas procíclicas encontram-se aderidas no tubo digestivo dos insetos vetores. No intestino do vetor as promastigotas passam por um processo chamado metaciclogênese, onde elas deixam de se reproduzir e se tornam infectantes, nesse processo elas sofrem modificações bioquímicas na sua superfície, perdendo a capacidade de se aderir ao epitélio do intestino médio do flebótomo. Assim 
as promastigotas metacíclicas destacam-se migrando para a cavidade bucal, onde elas são transmitidas ao hospedeiro vertebrado no repasto sanguíneo. ${ }^{37,44,48}$

Figura 6. Diferentes morfologias da leishmaniose: (A) amastigotas; (B) promastigotas.

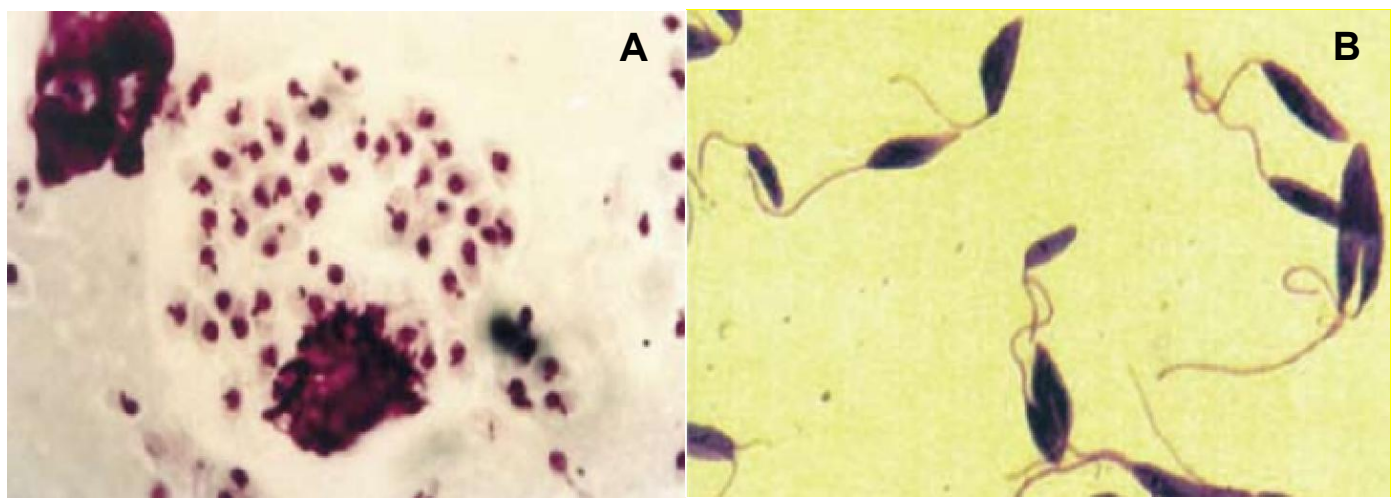

Fonte: Ministério da saúde: Manual de vigilância da leishmaniose tegumentar Americana (LTA), 2007.

No hospedeiro vertebrado as promastigotas precisam sobreviver ao mecanismo de defesa. As alterações ocasionadas pela metaciclogênese conferem uma resistência maior as promastigotas. Substâncias presentes na saliva no vetor, também favorecem a infecção. ${ }^{37,44}$

A principal célula de defesa do vertebrado é o macrófago, que internaliza os parasitos formando dentro dela um vacúolo parasitóforo, onde tem-se substâncias responsáveis pela destruição de microrganismos. As amastigotas desenvolveram mecanismos de defesa capazes de subverter sua capacidade microbicida, conseguindo sobreviver neste ambiente potencialmente tóxico e se multiplicar. ${ }^{37,48}$

As fêmeas do inseto vetor exercem o repasto sanguíneo no hospedeiro vertebrado infectado, ingerindo, assim, macrófagos infectados com formas amastigotas do parasito. No intestino do flebotomíneo, os parasitos são liberados e em algumas horas já se encontram formas promastigotas parasitando o intestino médio do vetor. Inicia-se um processo chamado metaciclogênese, que resulta no aparecimento de promastigotas metacíclicas, capazes de se desprender do intestino do inseto. Livres no lúmen intestinal, elas poderão ser inoculadas em um hospedeiro vertebrado quando o inseto efetuar um novo repasto sanguíneo e, assim, infectar células fagocitárias mononuleares. ${ }^{41,43}$ 
Figura 7. Ciclo biológico da leishmaniose.

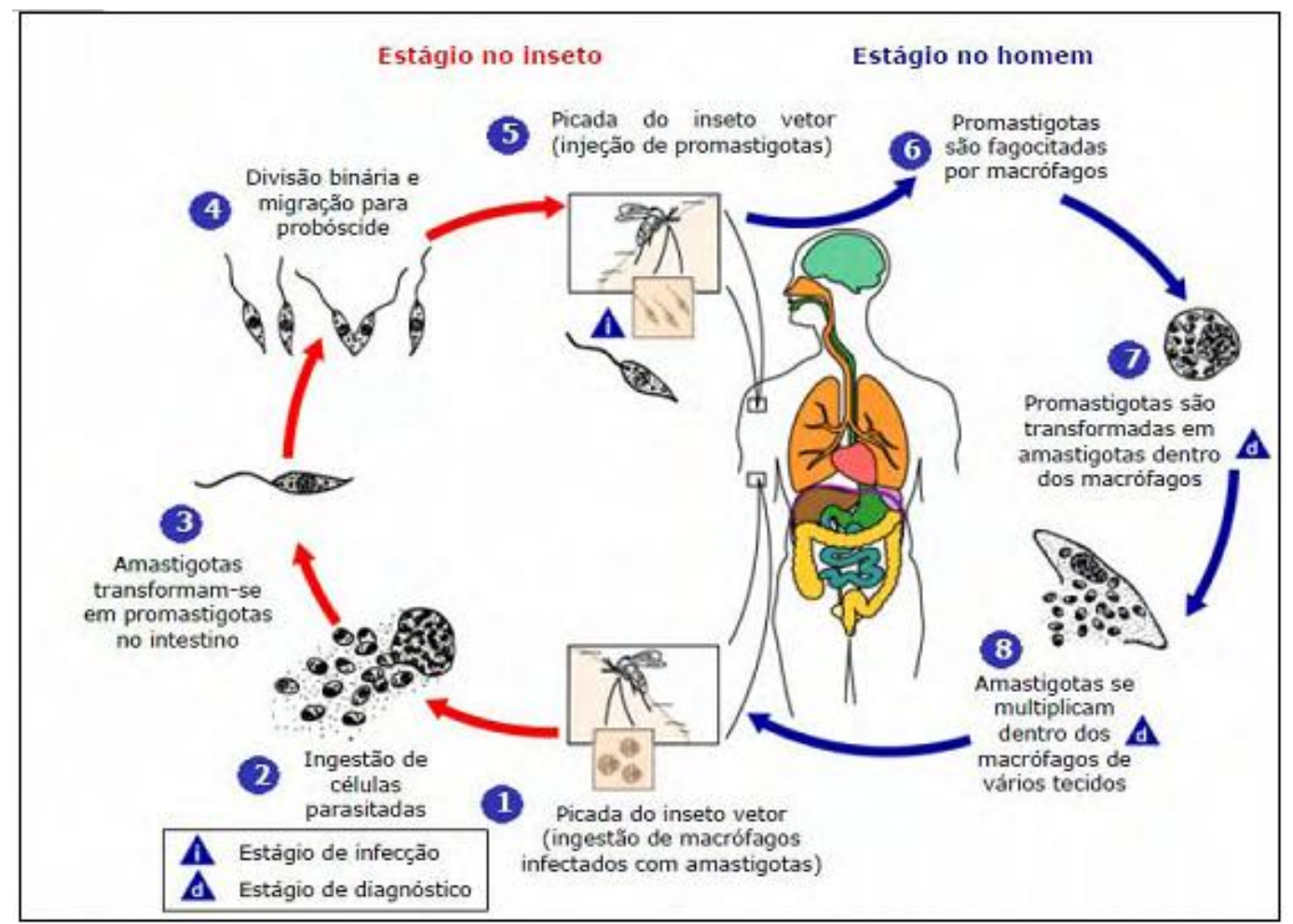

Fonte: http://www.dpd.cdc.gov/dpdx

\subsubsection{Tratamento}

O tratamento de primeira escolha é baseado em antimoniais pentavalentes, que foram desenvolvidos há mais de 60 anos, Figura 8. Dois fármacos estão disponíveis atualmente, o estibogluconato de sódio (Pentostam ${ }^{\circledR}$, GlaxoSmithKline) e o antimoniato- $N$-metil glucamina (Glucantime ${ }^{\circledR}$, Aventis). Os antimoniais trivalentes, extremamente tóxicos, foram substituídos pelos antimoniais pentavalentes a partir de 1920 e, a partir dos anos 40, passaram a representar os medicamentos de primeira escolha para o tratamento das leishmanioses, embora seu mecanismo de ação não seja conhecido até o momento. ${ }^{38}$

Altas doses diárias são requeridos por longos períodos de tempo (20-40 dias), pois o tempo de meia-vida na corrente sanguínea é pequeno e também devido ao surgimento de resistência do parasito a terapia. Efeitos severos como trombose, toxidez hepática, hipersensibilidade e choque anafilático são apresentadas após o início do tratamento. ${ }^{49,50}$ 
Figura 8. Representação estrutural dos antimoniais usados como terapias de primeira escolha.

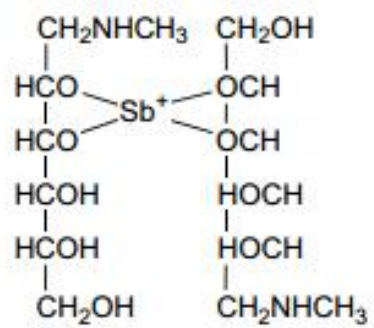

Glucantime $^{\circledR}$

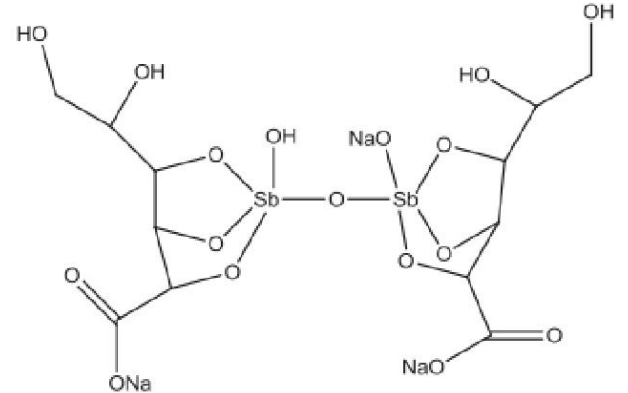

Estibogluconato de sódio

Os tratamentos de segunda escolha são: anfotericina B (Fungisone ${ }^{\circledR}$, Bristol Meyers Squibb) e pentamidina (Figura 9). A administração da anfotericina B é feita por via intravenosa e é a terapia mais eficaz, atuando em ambas as morfologias (promastigota e amastigota) através da ligação aos ésteres presentes na membrana do parasita. Ela é altamente efetiva no tratamento de leishmanioses resistentes a antimoniais, mas apresenta efeitos colaterais como anafilaxia, trombocitopenia, anorexia, anemia, dor muscular, febre, tremor, calafrio, disfunção renal, entre outros. Novas formulações associadas a lipossomas e a dispersão coloidal apresentam maior tempo de meia-vida e menor toxidez, porém seu elevado custo limita o seu uso sistemático pelo serviço de saúde pública. ${ }^{44,51,52}$

Uma diamina aromática, a pentamidina (Aventis), é utilizada quando já há uma resistência aos antimoniais. É administrada por via endovenosa, porém apresenta efeitos colaterais severos como taquicardia, hipotensão, dores de cabeça, vômitos, náuseas, erupção cutânea, disfunção renal, hipo/hiperglicemia.

Os métodos mais comuns para a prevenção da leishmaniose são a desinsetização das áreas de risco para a erradicação do vetor, uso de mosquiteiros, aplicação de inseticidas sobre a pele. O sacrifício de cães infectados também é importante, pois eles são reservatórios da doença. ${ }^{51-53}$ 
Figura 9. Representação estrutural dos fármacos de segunda escolha.

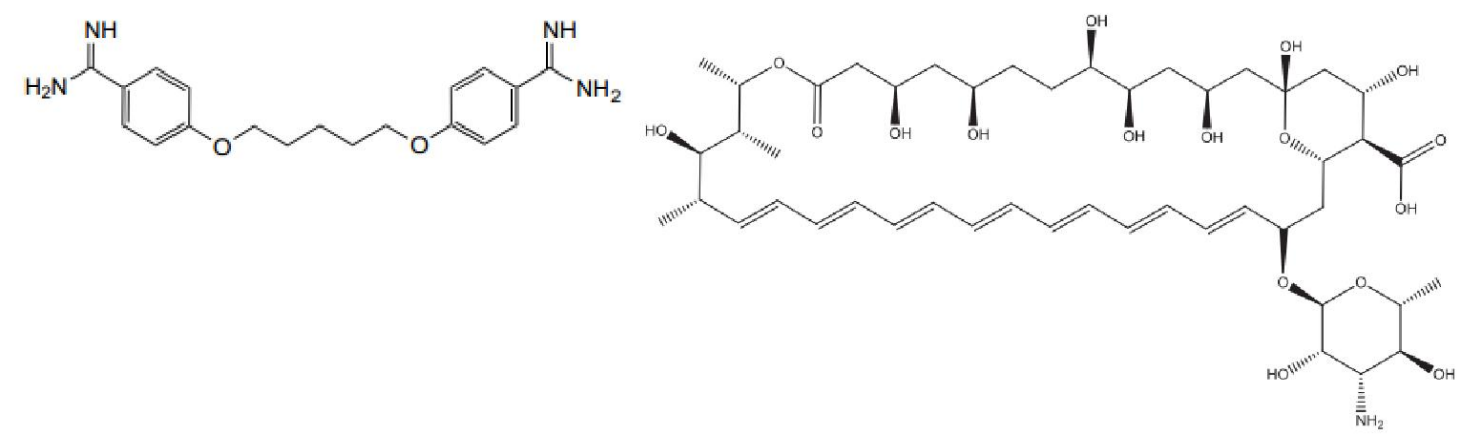

Pentamidina

Anfotericina B

\subsubsection{Química Medicinal}

O planejamento e o desenvolvimento de candidato a fármaco compreende um processo longo, oneroso, complexo e de muitas fases. No final apenas uma pequena fração dessas moléculas é selecionada para continuar no processo de desenvolvimento de um novo fármaco. Embora seja um processo com elevada taxa de erros, o benefício clínico para milhares de pacientes é uma incessante motivação para o contínuo investimento nesta área, sendo o(a) químico(a) medicinal de grande relevância neste contexto. ${ }^{54}$

Para iniciar a pesquisa de novas substâncias bioativas, deve-se avaliar qual estratégia será abordada. Uma delas envolve o conhecimento da importância de um alvo macromolecular para a patologia, por meio de validação deste alvo, além da descrição de sua estrutura tridimensional para a realização do planejamento baseado na sua estrutura (TBDD). ${ }^{55}$

A doença de Chagas, uma das doenças tropicais e negligenciadas, obteve consideráveis avanços na descrição de aspectos biológicos, genéticos e evolucionários do Trypanosoma cruzi, protozoário responsável pela doença. A caracterização do seu genoma contribuiu para a identificação de vários alvos biológicos, principalmente enzimas. ${ }^{54,55}$ 
A partir deste conhecimento, a triagem de compostos anti-chagásicos pode ser realizada por ensaios in silico, in vitro e/ou in vivo ${ }^{54}$. No ensaio in silico, são realizados estudos computacionais baseados nos compostos bioativos conhecidos (LBVS) e nas estruturas das macromoléculas (TBVS). No ensaio in vitro bioquímico são testados os compostos frente aos seus alvos enzimáticos. Esses testes são realizados no Grupo de Química Medicinal (NEQUIMED) com a coordenação do Prof. Carlos A. Montanari. A partir da detecção da atividade biológica no ensaio bioquímico, realiza-se o ensaio celular com os compostos de interesse. O ensaio celular é o primeiro estudo onde um organismo vivo é utilizado e constitui-se como a ponte entre os ensaios bioquímicos e os estudos em animais. Em uma próxima etapa, o ensaio in vivo é realizado em modelos animais que mimetizam a patologia.

Devido à grande relevância do ensaio celular, o presente trabalho visa estudar a atividade biológica de novas substâncias previamente selecionadas a partir de ensaios enzimáticos em modelos utilizando o agente causador da doença de Chagas (T. cruzi) ${ }^{56}$ e leishmaniose cutânea (L. amazonensis) e visceral (L. chagasi).

\subsubsection{Alvos enzimáticos}

As enzimas descritas nos próximos itens têm sido implicadas em mecanismos de adaptação para a sobrevivência do parasito no hospedeiro, incluindo a modulação do sistema imune do hospedeiro, invasão e destruição de tecidos, disseminação do parasito e aquisição de nutrientes essenciais que assegurem a sobrevivência e proliferação para manter a infecção. ${ }^{57-60}$

Assim os parasitos garantem sua perpetuação dentro de seus hospedeiros através da produção de enzimas, que ativam mecanismos de sobrevivência, por conseguinte estas macromoléculas são alvos potenciais para o desenvolvimento de novos fármacos. ${ }^{61}$

\subsubsection{Cruzaína}

Para a doença de Chagas e leishmaniose, as proteases (que são responsáveis por clivar ligações peptídicas) são cruciais no ciclo de vida e patogenia. ${ }^{62-64}$ Diversos 
tipos de proteases são expressas em diferentes fases do ciclo de vida do parasita e desempenham importantes funções na replicação do parasita e metamorfose. ${ }^{62}$

Modificações durante o ciclo de vida dos protozoários podem estar condicionadas à presença dessas proteases. Existem características marcantes do ciclo de vida dos protozoários e remodelamento morfológico que eles sofrem durante o seu desenvolvimento em ambos os hospedeiros (vertebrados e vetores), devido a fatores ambientais desencadeados pelo meio extracelular (no caso de epimastigota, tripomastigota e promastigota) e o meio intracelular (para as amastigotas). Em todas essas alterações morfológicas estão envolvidas reestruturação de organelas (flagelo e cinetoplasto) e rearranjo do citoesqueleto. ${ }^{65}$

A cruzaína, expressa como cruzipaína ou GP57/51, está presente em vários estágios do T. cruzi. Algumas isoformas são liberadas pelas tripomastigotas, sendo este um fator de virulência para a doença de Chagas. ${ }^{60,66}$ Essa enzima promove também um mecanismo pelo qual o parasito pode escapar da resposta imune do hospedeiro. ${ }^{67-69}$

As proteases extracelulares do parasito têm um papel crucial no seu ciclo de vida e na patogenia, pois têm sido associadas a uma ampla variedade de mecanismos de adaptação para a sobrevivência do parasito no hospedeiro. ${ }^{62}$ Além da modulação da resposta do sistema imune, também estão envolvidas na invasão e destruição de tecidos, capacidade do parasito migrar para locais específicos para o crescimento e desenvolvimento, além de adquirir nutrientes essenciais que garantem a sobrevivência e proliferação para manutenção da infecção. ${ }^{58,62}$

Na leishmania, as cisteíno proteases mais estudadas são três isoformas que são do tipo papaína e pertencem ao mesmo grupo de cisteíno proteases, denominadas CPA e CPB (que são do tipo catepsina $L$ em célula de mamífero) ${ }^{57} \mathrm{e}$ CPC, tipo catepsina B. ${ }^{70}$ As enzimas do tipo CPB são encontradas nos megassomos (lisossomos largos), nos vacúolos parasitóforos e extracelularmente nas lesões, dando a estas enzimas a oportunidade de interagirem com as proteínas do hospedeiro. 71

Estas cisteíno proteases são pouco expressas nas formas promastigotas procíclicas, porém mais abundante nas formas promatigotas metacíclicas e principalmente nas formas amastigotas do parasito. ${ }^{72}$ São importantes fatores de 
virulência que modulam a resposta imune do hospedeiro e parecem possuir um papel vital na sobrevivência do parasito nos macrófagos. ${ }^{57}$

\subsubsection{Di-idroorato desidrogenase}

A síntese de nucleotídeos é essencial para o desenvolvimento de todos e quaisquer organismos, pois participam como unidades fundamentais dos ácidos nucleicos (DNA e RNA) e também atuam como ativadores e inibidores de várias vias de metabolismo intermediários da célula. ${ }^{73}$

As enzimas DHODH são divididas em famílias 1 e 2, que estão relacionadas com a localização celular, propriedades funcionais e características estruturais. A família 1 está localizada no citosol e está dividida em dois subgrupos A e B. DHODHs da família $1 \mathrm{~A}$ são proteínas homodiméricas, enquanto que na família 1B elas são heterotetraméricas. A família 1 é encontrada em bactérias do tipo Gram-positivas e fungos anaeróbicos e apresentam identidade sequencial com a família 2 de $20 \% .{ }^{74}$

A família 2 está localizada associada a membrana citosólica ou mitocondrial, que é justificada pela presença de uma extensão N-terminal (denominada domínio de membrana) onde a presença de resíduos hidrofóbicos permitem a interação da enzima com a membrana. Esta família é encontrada em eucariotos superiores e alguns procariotos como bactérias gram-negativas. ${ }^{75}$

A DHODH do T. cruzi, cepa Y, é baseada em uma sequência de 314 resíduos de aminoácidos, com massa molecular de $34.052 \mathrm{Da}$, classificada como membro da família $1 \mathrm{~A}$. As células que replicam rapidamente, incluindo os parasitos, não conseguem reciclar a quantidade necessária de nucleosídeos através da via de salvação, portanto, dependem da biossíntese de novo para obter os nucleotídeos. ${ }^{74,75}$ Esta macromolécula catalisa a quarta etapa da biossíntese de novo de nucleotídeos de pirimidina levando a oxidação do (S)-di-idroorotato (DHO) a orotato (ORO), com redução do fumarato (FUM) a succinato (SUC). Esta reação catalítica promovida pela enzima é a única etapa de oxidação-redução na síntese de novo de pirimidina. ${ }^{75}$ 


\subsubsection{Giceraldeído-3-fosfato desidrogenase (GAPDH)}

A GAPDH é uma enzima glicolítica clássica, que tem papel fundamental na produção de energia. Ela é tetramérica, com subunidades idênticas (359 resíduos) e massa molecular de $156 \mathrm{kDa}$. Esta catalisa a conversão reversível do substrato gliceraldeído-3-fosfato (GAP) em 1,3-bifosfoglicerato (1,3-BPG) na presença do cofator $\mathrm{NAD}^{+}$e fosfato inorgânico (Figura 10). ${ }^{76,77}$

Figura 10. Reação enzimática catalisada pela GAPDH.

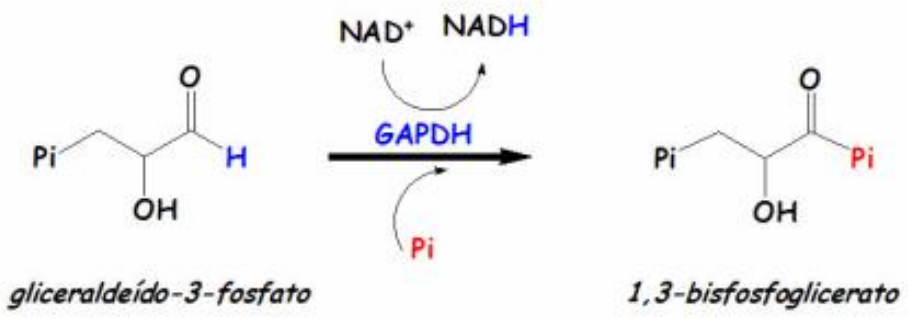

Fonte: http://www.inbeqmedi.ifsc.usp.br/doencas_de_chagas.php

A GAPDH de mamíferos é classificada como uma proteína multifuncional, pois está envolvida em vários processos celulares como apoptose, atividade RNase, transporte nuclear de RNA, replicação de DNA e fusão da membrana celular. ${ }^{78,79}$

Essa enzima é considerada um alvo molecular promissor para o desenvolvimento de novas moléculas bioativas antiparasitárias, visto que apresenta similaridade estrutural quando comparada a enzima humana de aproximadamente 45 $\%$ (identidade sequencial) e, por isso, podem ser investigadas para a inibição seletiva dos parasitas. ${ }^{80-84}$

\subsubsection{Quinases}

A ligação da maioria das moléculas sinalizadoras com seus receptores inicia uma série de reações intracelulares, através de vias de sinalização, que regulam todos os aspectos do comportamento celular, incluindo metabolismo, movimento, proliferação, sobrevivência e diferenciação. ${ }^{85} \mathrm{~A}$ sinalização celular é feita por sistemas 
de regulação, envolvendo proteínas quinases, fosfatases, proteína $\mathrm{G}$ e mensageiros secundários. ${ }^{86}$

A família das proteínas quinases possui centenas de membros, tendo em comum o centro catalítico, que se constitui de uma sequência de onze subdomínios conservados, e a capacidade de catalisar a fosforilação dos resíduos de serina, treonina ou tirosina, retirando o fosfato de um grupo altamente energético (ATP). ${ }^{87}$

Em animais, a fosforilação de proteínas tem um papel bem conhecido em diversos processos celulares como metabolismo de glicogênio, controle do ciclo celular e transdução de $\operatorname{sinais}^{88}$ que regulam o crescimento e a diferenciação celular.

$\mathrm{O}$ ciclo celular consiste em quatro fases primárias: $\mathrm{G}_{1}$, a primeira fase do ciclo onde ocorre a síntese protéica; fase $S$, na qual a síntese de DNA ocorre; $\mathrm{G}_{2}$, fase intermediária entre a fase $\mathrm{S}$ e a $\mathrm{M}$; e a fase $\mathrm{M}$, ou mitose, na qual os cromossomos e os componentes citoplasmáticos são divididos entre duas células filhas ao final do processo. As transições entre essas fases do ciclo são rigidamente reguladas, e pontos de checagem durante o ciclo celular permitem a verificação dos constituintes celulares antes de começar a próxima fase do ciclo.89-91 Para tudo ocorrer perfeitamente, um grupo de proteínas atua como fundamental regulador das transições do ciclo celular, as quinases dependentes de ciclina (CDKs), que são uma família de proteínas serina/treonina quinases dependentes da ligação com as ciclinas para sua ativação.

Figura 11. Representação esquemática do ciclo celular

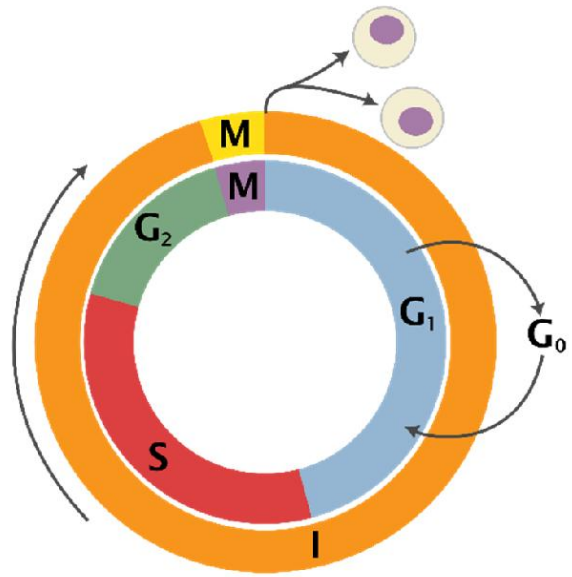

Fonte: http://creationwiki.org/pt/Ciclo_celular. O ciclo celular compreende quatro fases: G1-síntese proteica, S- duplicação do material genético, G2- crescimento celular e M- mitose, duplicação da célula. 
As proteínas quinases são a maior família de proteínas em eucariotos, e são a chave central da comunicação intracelular, regulação e transdução de sinais. ${ }^{89,90}$ Por isso torna-se interessante a descoberta de novas substâncias bioativas, que bloqueia o ciclo celular, inibindo a proliferação do parasito.

Estes estudos baseados nas alterações fenotípicas in vitro independem do mecanismo de ação das substâncias bioativas e podem ser aplicados para substâncias de diferentes classes e que possuem diversos alvos macromoleculares. 


\section{Objetivo}

Este trabalho tem a finalidade de descobrir novas substâncias bioativas com atividade antichagásica e antileishmanicida a partir de ensaios celulares que usam a forma epimastigota da cepa $Y$ do Trypanosoma cruzi e a forma promastigota da Leishmania amazonensis e Leishmania chagasi. Assim, relações entre a estrutura química e a atividade biológica (SAR) são estabelecidas através do estudo da viabilidade celular.

\section{Objetivos específicos}

Para que o objetivo geral seja alcançado, faz-se necessário:

* Estabelecer o protocolo de cultura do parasito;

- Padronizar o método colorimétrico (MTT) e de citometria de fluxo (Via Count ${ }^{\circledR}$ ) para observar e quantificar a viabilidade do parasito;

* Realizar as triagens e quantificar a resposta biológica para as substâncias de interesse a partir da curva concentração-resposta e o $\mathrm{IC}_{50}$ por meio do ensaio colorimétrico de MTT;

* Analisar a perturbação no ciclo celular causada pelas substâncias de referência. 


\section{Materiais e Métodos}

\subsection{Parasitos}

A forma epimastigota da cepa $Y$ do $T$. cruzi foi cultivada em meio LIT (Liver Infusion Tryptose) e mantida em crescimento em $28^{\circ} \mathrm{C}$ na estufa. Para o repique, a cada 10 dias foi realizada a passagem para um meio de cultura rico em nutrientes, com transferência de $1 \mathrm{~mL}$ dos parasitos para um novo falcon (BD) de $50 \mathrm{~mL}$ e adição de $19 \mathrm{~mL}$ de meio novo.

As formas promastigotas da $L$. amazonensis e $L$. chagasi (sensíveis ao óxido nítrico) foram cultivadas em meio 199 a $24{ }^{\circ} \mathrm{C}$ na estufa. Os parasitos foram gentilmente cedidos pelo Prof. Dr. Sérgio de Albuquerque (Faculdade de Ciências farmacêuticas de Ribeirão Preto-FCFRP-USP). As culturas foram mantidas em $24^{\circ} \mathrm{C}$, com suplementação de meio duas vezes na semana, ou seja, foi retirado todo o líquido e adicionado meio rico em nutrientes. Uma vez na semana foi realizada a passagem para um novo frasco, onde $0,5 \mathrm{~mL}$ dos parasitos velhos é transferido para um frasco T25 (TRP) novo, seguido da adição de $10 \mathrm{~mL}$ de meio.

\subsection{Meio de Cultura}

O meio de cultura LIT utilizado para a propagação do T. cruzi (epimastigota) é constituído por hemina bovina (Sigma-Aldrich), glicose 1\% (Life Technologies-Gibco), infuso de fígado (Sigma-Aldrich), triptose (Amresco) estreptomicina-penicilina (Vitrocell) e suplementado com $10 \%$ de soro fetal bovino ${ }^{92}$ (Vitrocell).

O meio de propagação das espécies de leishmania utilizado neste trabalho é comumente comercializado (meio 199, Sigma-Aldrich), suplementado com Lglutamina 10\% (Sigma-Aldrich), bicarbonato de sódio 0,22\% (Sigma-Aldrich), estreptomicina-penicilina $0,5 \%$ (Vitrocell), urina masculina $2 \%$ e soro de feto bovino 10\% (Vitrocell) $)^{31,32}$. 


\subsection{Compostos}

O grupo possui um banco de dados onde estão organizados todos os compostos que são planejados e, na maioria das vezes, sintetizados pelo grupo NEQUIMED. Portanto todos os compostos possuem a inicial Neq e, no sufixo, um número que corresponde a ordem a qual foi adicionada ao banco de dados.

Neste item segue uma tabela com todos os compostos testados contra as enzimas cruzaína, diidroorotato desidrogenase (DHODH), gligeraldeído-3-fosfato desidrogenase (GAPDH), e quinases, e suas respectivas nomenclaturas (Tabela 1).

A solubilização de todos os compostos foi realizada em DMSO puro e filtrado para compor a solução estoque. A concentração final de DMSO nos ensaios é de 0,5\%, com diluição no meio de cultura do respectivo parasito. Os compostos de referência Benzonidazol e Anfotericina B foram adquiridos da Sigma Aldrich.

Tabela 1. Estruturas químicas das novas substâncias ensaiadas neste trabalho

\section{Inibidores de cruzaína}

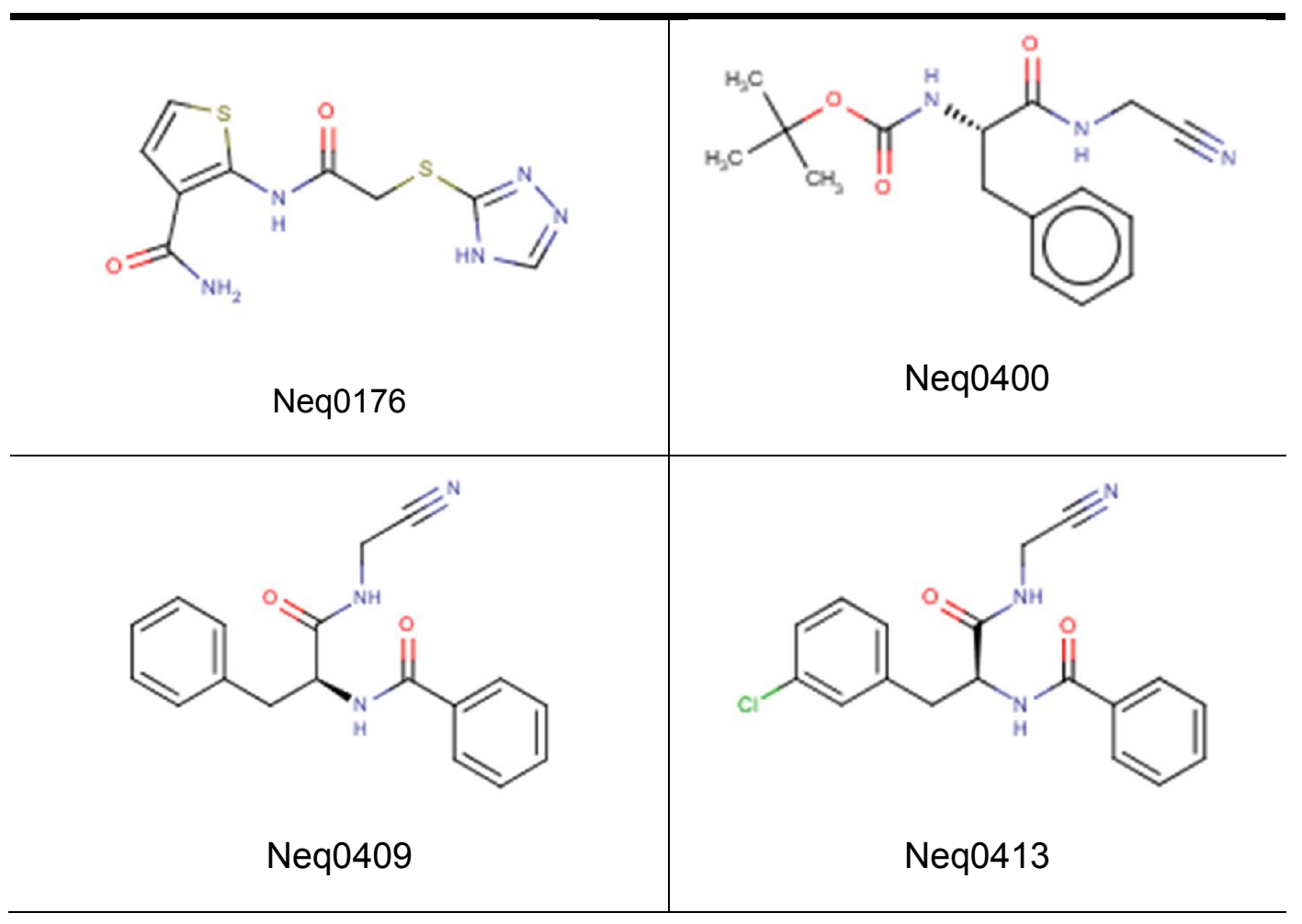




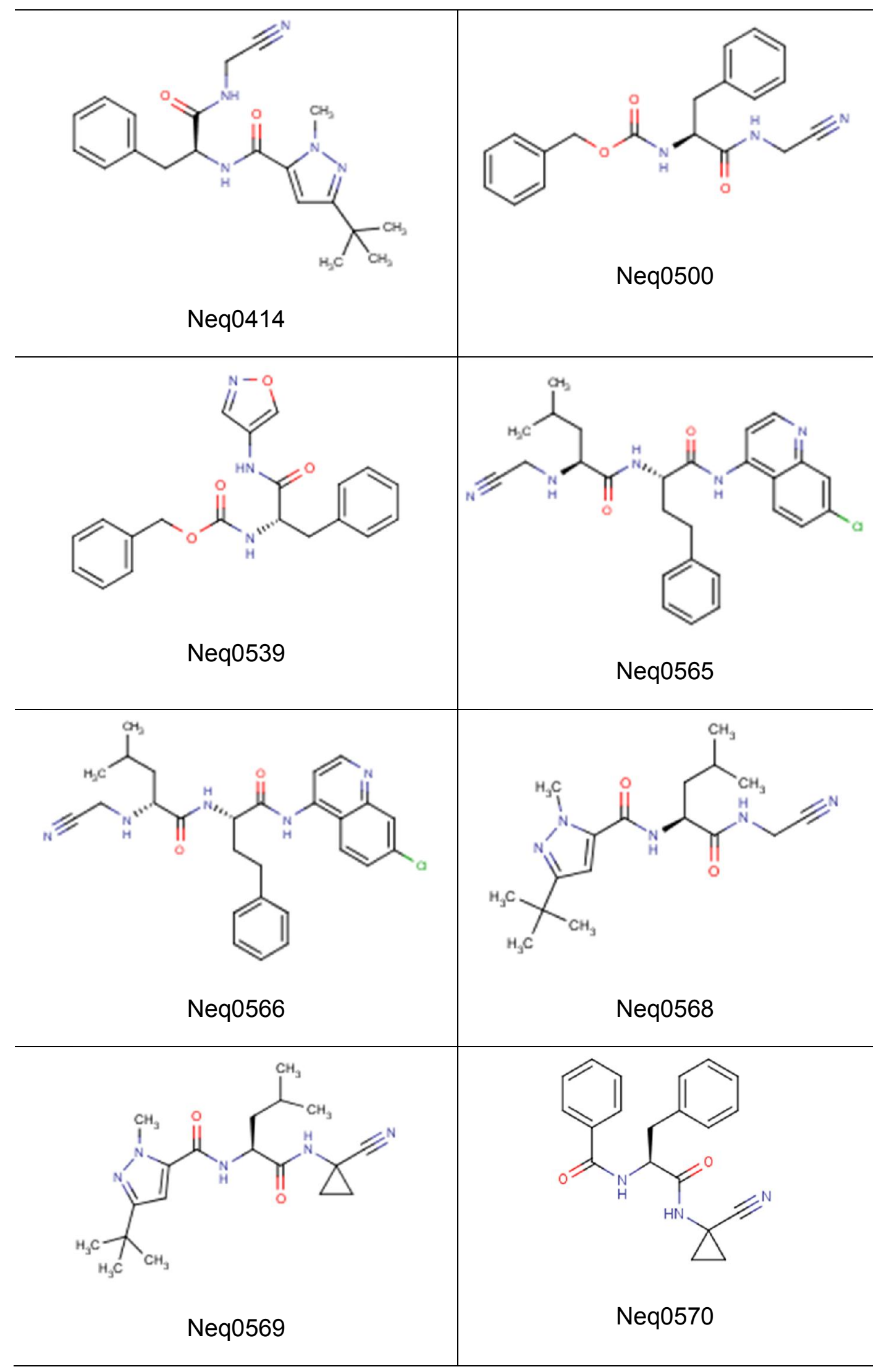




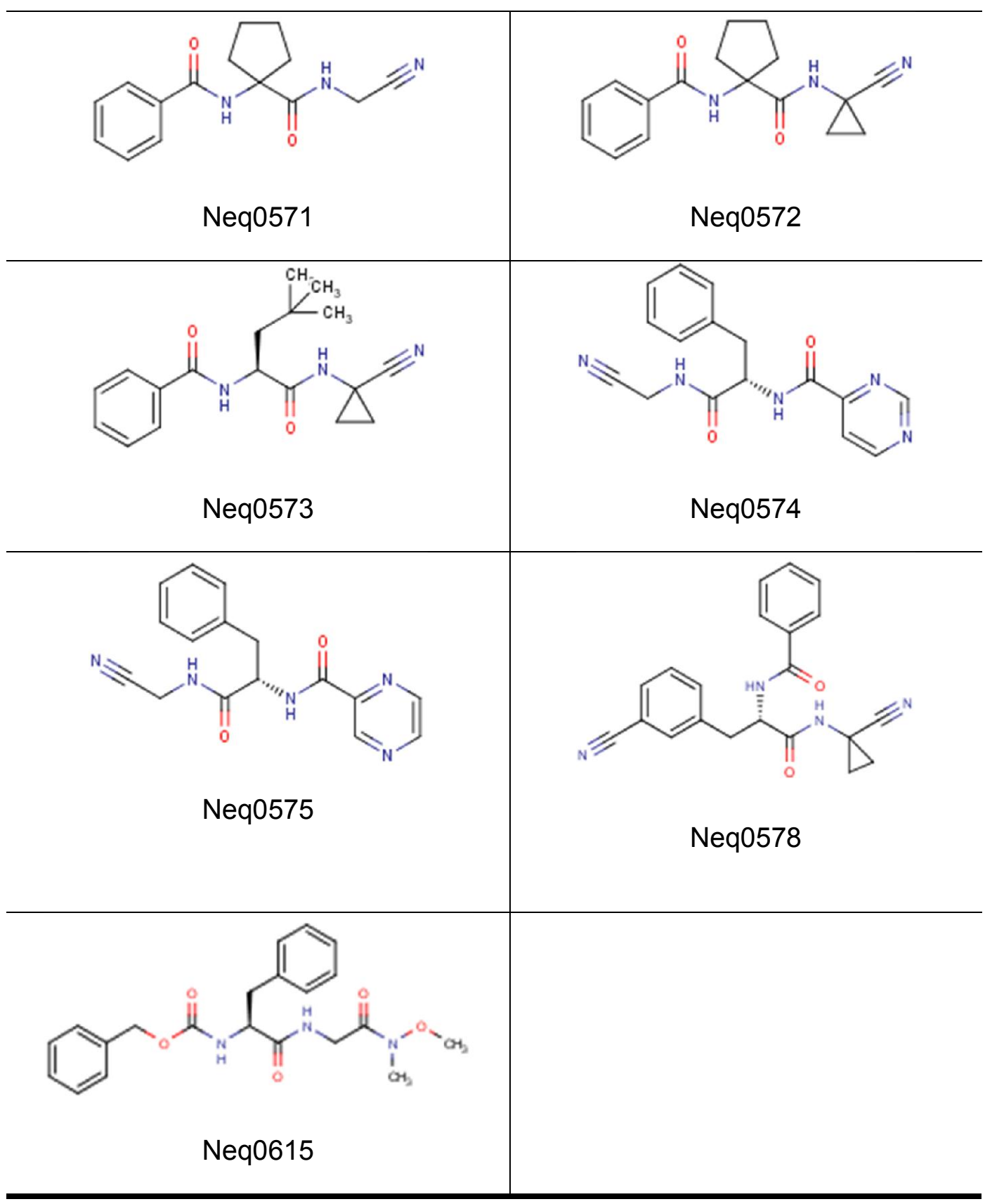

Inibidor de DHODH

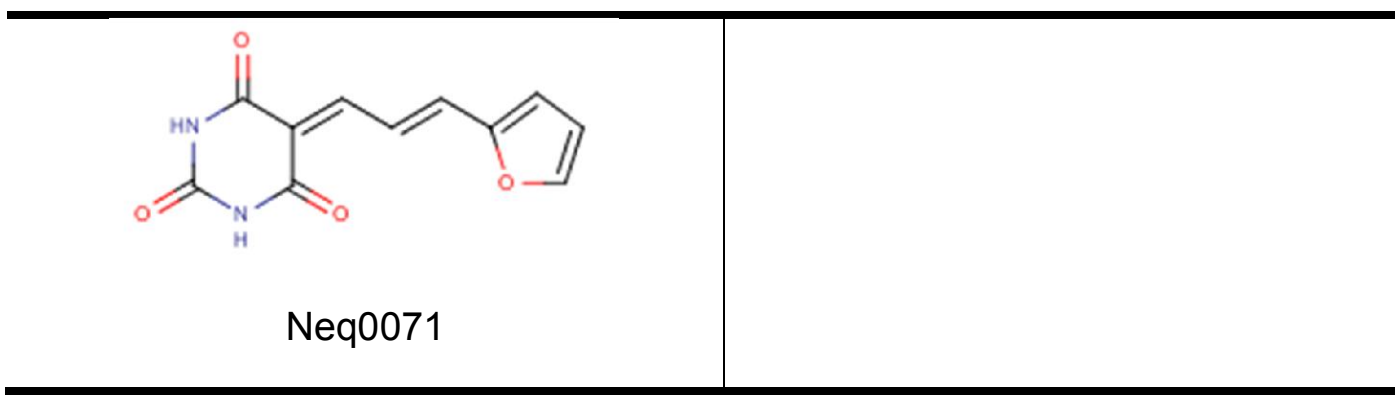




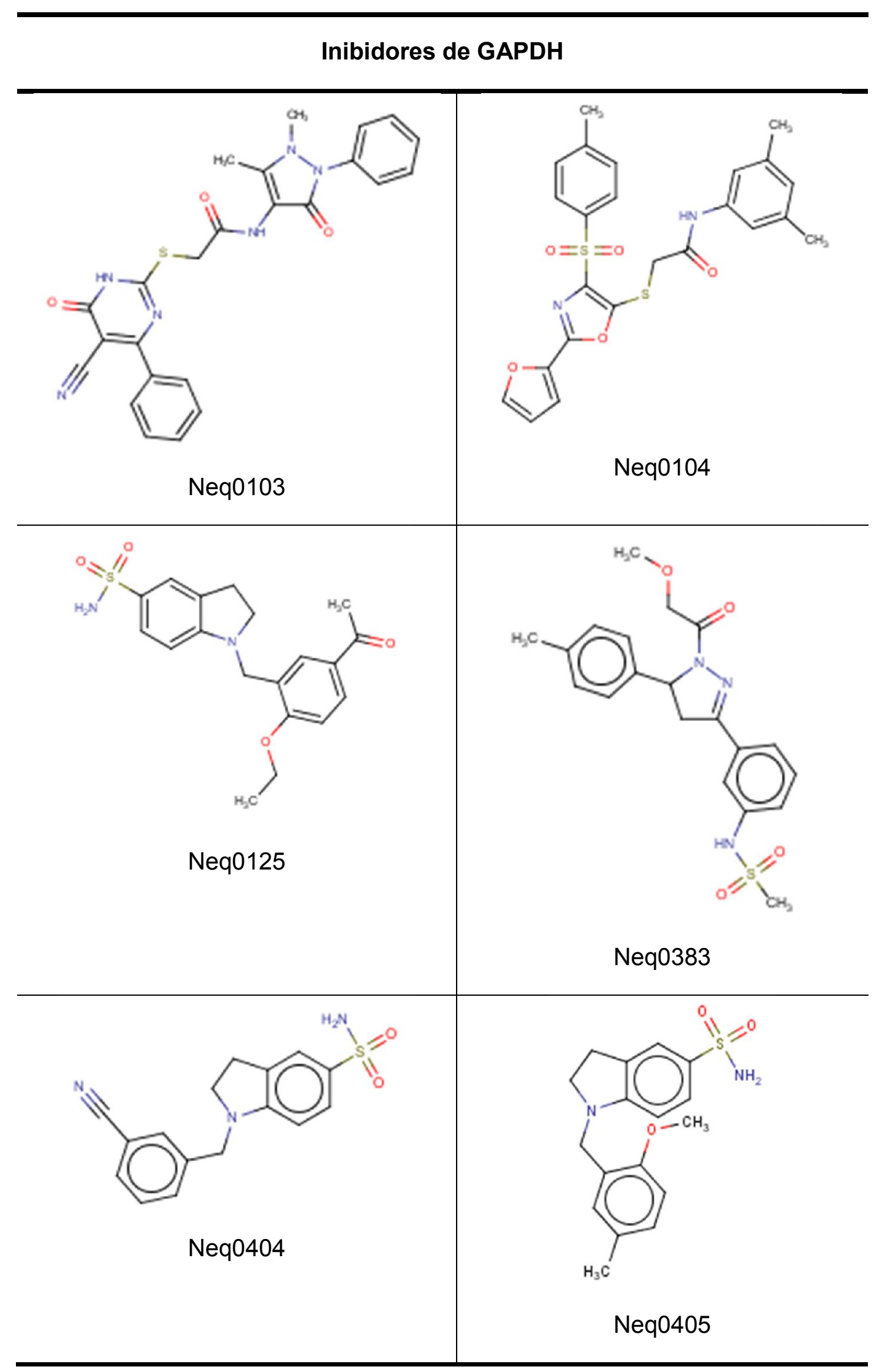




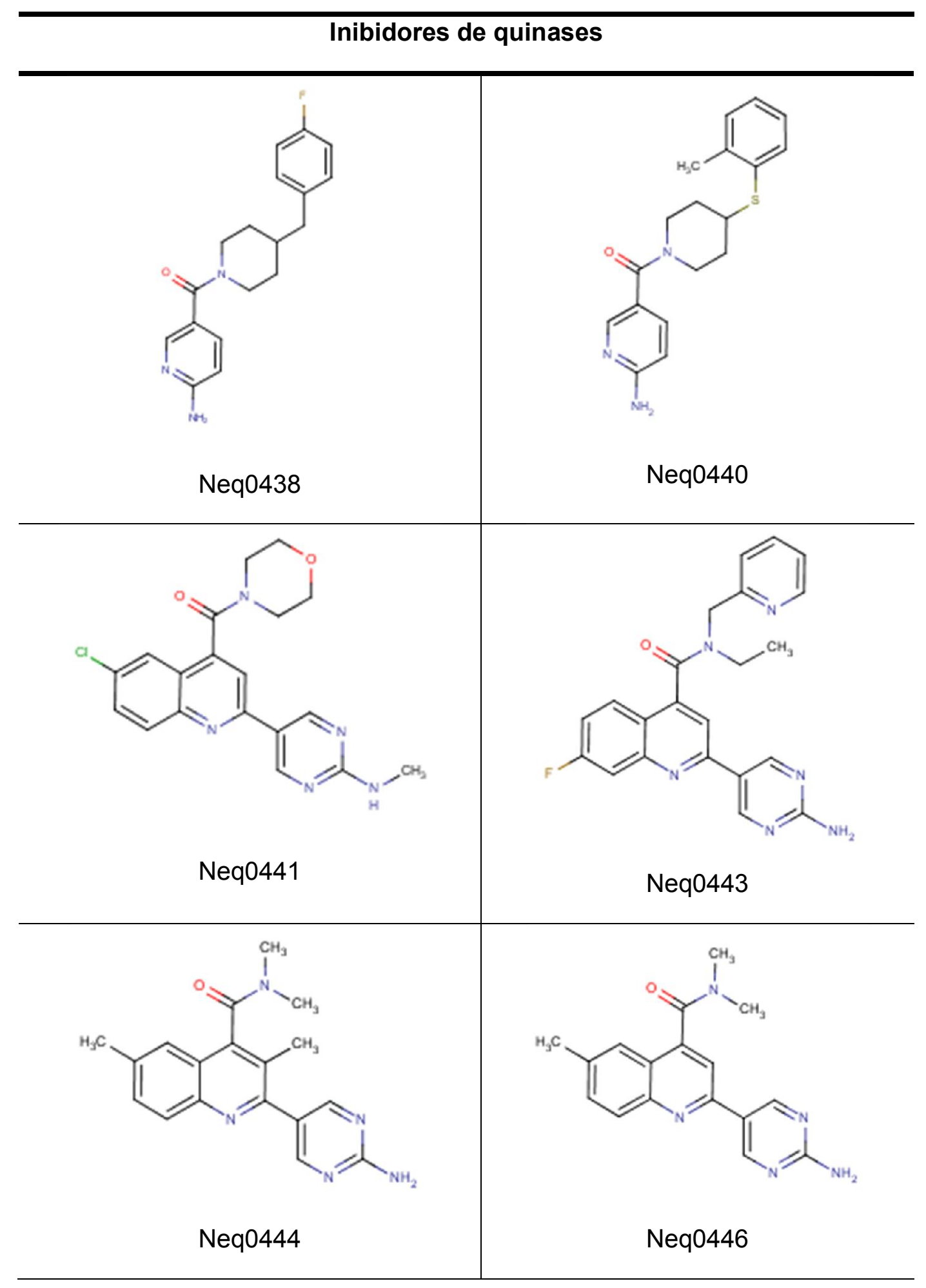




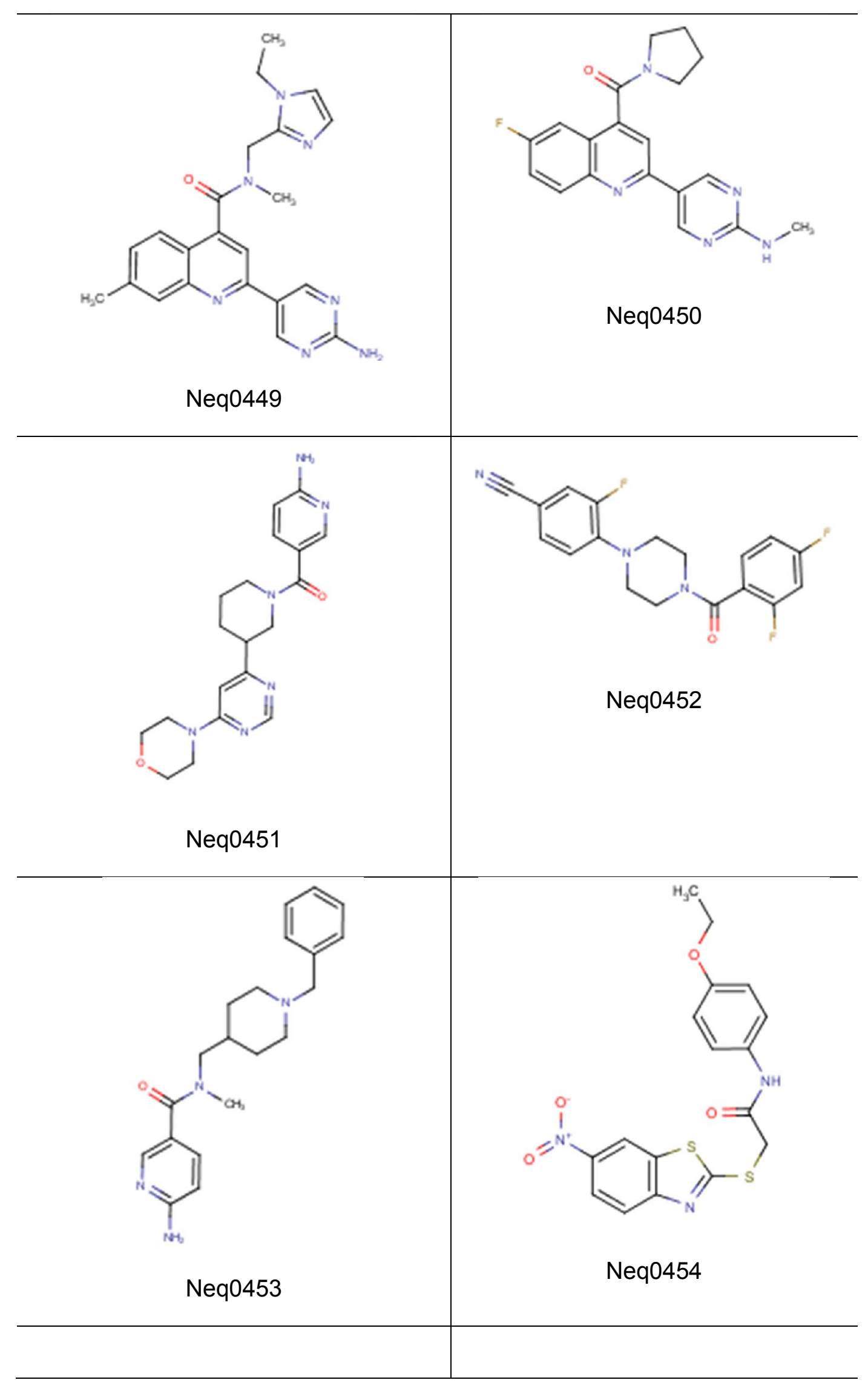




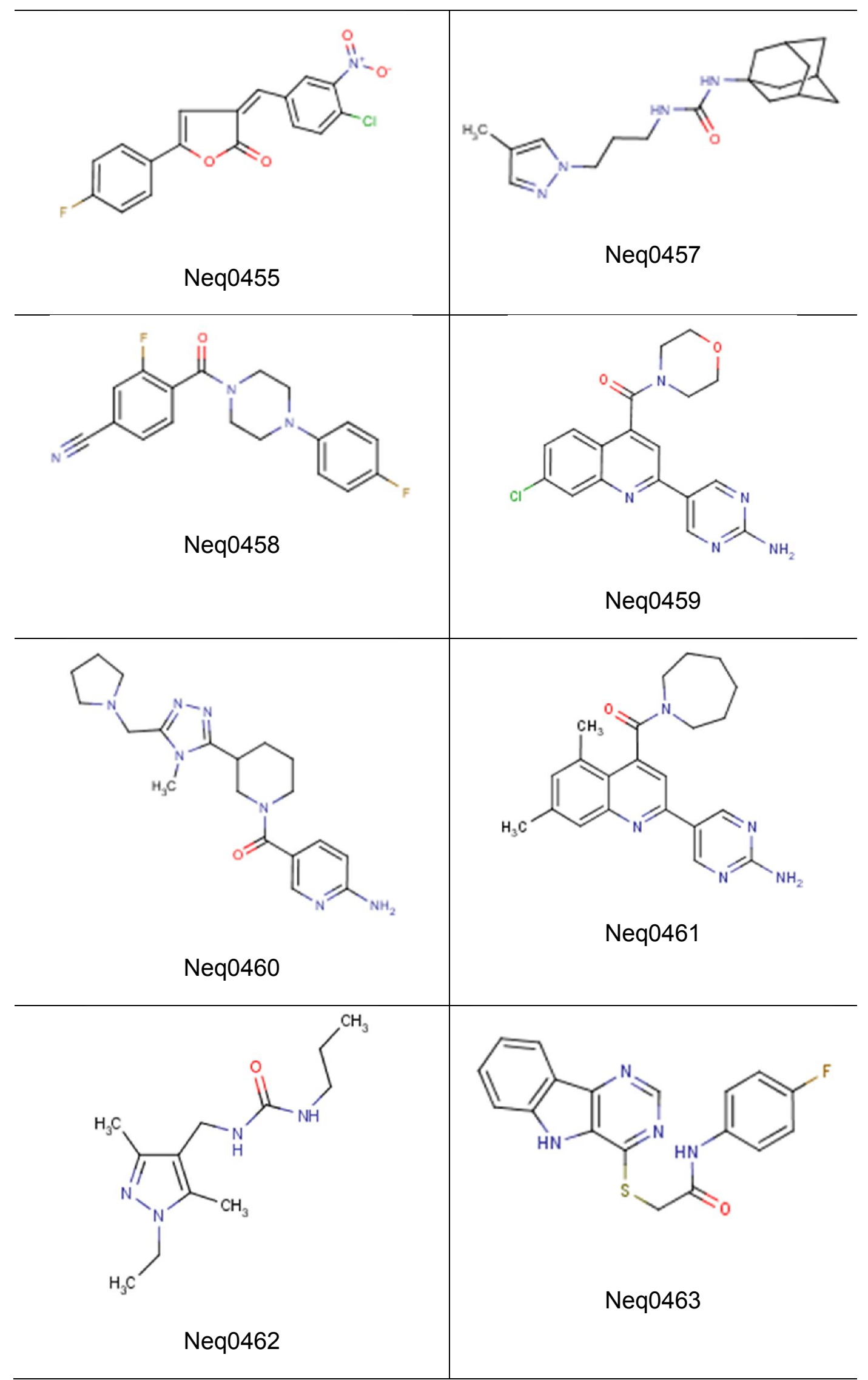




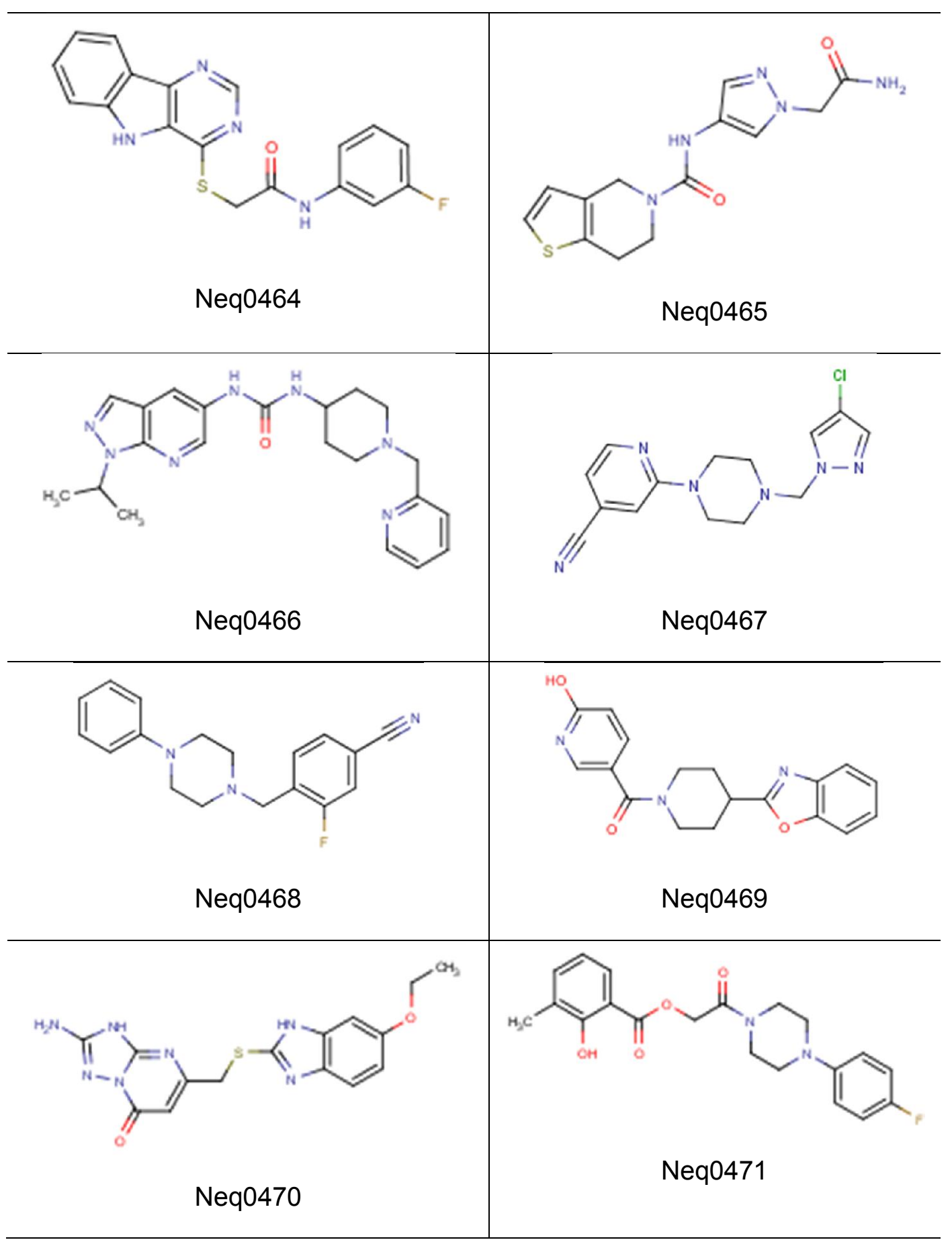




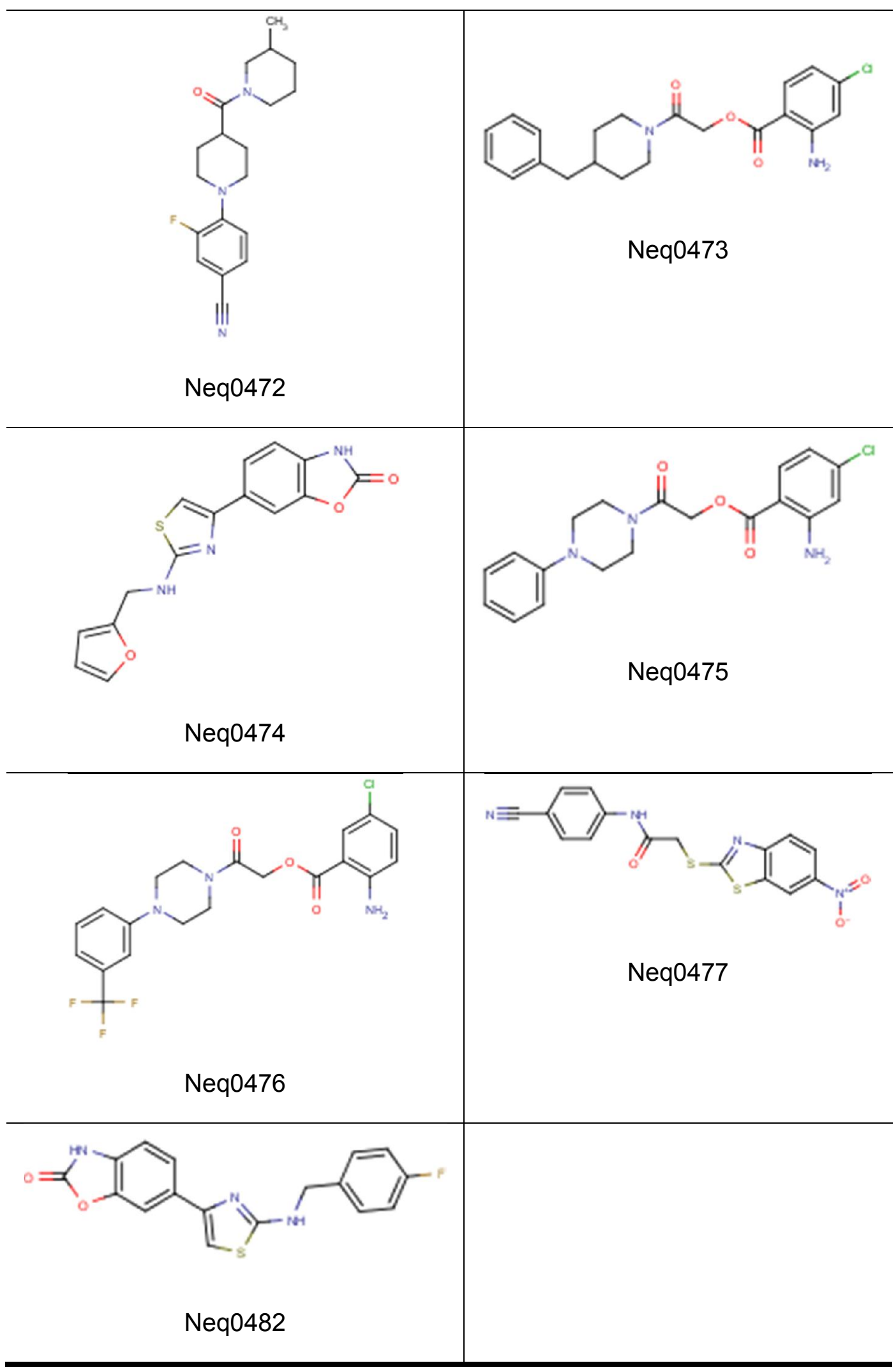




\subsection{Método colorimétrico}

Muitas variáveis foram testadas para atingir as condições ótimas de ensaio. As culturas foram mantidas em crescimento, quando é atingida a fase exponencial (fase log) os parasitos foram usados para os ensaios.

A solução de MTT (brometo de 3-(4,5-dimetil-2-tiazolil)-2,5-difenil-2Htetrazólio) Erro! Indicador não definido,,93-95 foi preparada na concentração de $5 \mathrm{mg} / \mathrm{mL}$ junto com PMS 0,22 mg/mL (um carreador de elétrons) em tampão fosfato salino (PBS, Cultilab). A solução foi mantida sempre no escuro e, depois de diluída, foi esterilizada em filtro de seringa PVDF Merck-Millipore $0,22 \mu \mathrm{m}^{6}$.

O ensaio foi realizado em placas de 96 poços de fundo chato e transparente, onde $90 \mu \mathrm{L}$ de parasitos foram adicionados na concentração de $1 \times 10^{7}$ prasitas $/ \mathrm{mL}$ e adicionado $10 \mu \mathrm{L}$ de MTT. As placas foram incubadas por 4 horas (no escuro), respeitando as temperaturas de incubação de cada tipo de parasito. O MTT é metabolizado e assim os cristais de formazan são formados, estes são insolúveis em água e foram solubilizados com $100 \mu \mathrm{L}$ de agente solubilizante ${ }^{6}$ contendo uma solução de $70 \%$ de SDS a 10\% (Amresco) e $0,01 \mathrm{~mol} / \mathrm{L}$ de $\mathrm{HCl}$ (Vetec) e adicionando $30 \%(\mathrm{v} / \mathrm{v})$ de DMSO. Após 90 minutos de incubação foi realizada a leitura no espectrofotômetro BioTek Synergy HT em $570 \mathrm{~nm}^{96}$. A análise dos dados foi obtido através do GraphPad Prism v. 5 e Excel ${ }^{\mathrm{TM}}$.

\subsection{Citometria de fluxo}

\subsubsection{Viabilidade celular}

Primeiro foi realizado a contagem dos parasitos na câmara de Neubauer para a preparação de uma concentração de $1 \times 10^{7}$ parasitos $/ \mathrm{mL}$. Em uma placa estéril de fundo chato e transparente foram incubados $90 \mu \mathrm{L}$ do parasito e $10 \mu \mathrm{L}$ do composto na concentração desejada por cinco dias ( $T$. cruzi) e três dias (Leishmania spp.) de acordo com o protocolo estabelecido.

Para atingir uma concentração de trabalho ótima para o citômetro de fluxo foi necessário fazer diluições do parasito. Portanto, $10 \mu \mathrm{L}$ de cada poço foram transferidos para uma nova placa de fundo redondo e transparente, com adição de 40 
$\mu \mathrm{L}$ de PBS e $150 \mu \mathrm{L}$ do reagente ViaCount ${ }^{\circledR}$ (ou seja, uma concentração final de $5 \times 10^{5}$ parasitas $/ \mathrm{mL}$ ). Após 10 minutos de incubação foi realizada a leitura no equipamento citômetro de fluxo Guava EasyCyte ${ }^{\mathrm{TM}} 8 \mathrm{HT}$ (Merck-Millipore).

\subsubsection{Ciclo celular}

Foram incubados $90 \mu \mathrm{L}$ de parasito na concentração de $1 \times 10^{7}$ parasitos $/ \mathrm{mL}$ e $10 \mu \mathrm{L}$ do composto na concentração a ser estudada em uma placa estéril. Os tempos de incubações foram: 6 e 12 horas para Leishmania spp. e 48 horas para o tripanossoma. Realizamos a transferência do material para uma placa de fundo redondo, seguida de duas lavagens com PBS com 20\% de FBS intercaladas por centrifugação (450 g), adição de álcool etílico 70\% (200 $\mu \mathrm{L}$ ) e incubação por 12 horas. Depois do tempo transcorrido, duas lavagens com PBS (centrifugando em $450 \mathrm{~g}$ por 10 min.) foram seguidas pela adição de $100 \mu \mathrm{L}$ de PBS. Uma diluição de 10 vezes do parasita foi necessária, com transferência de $20 \mu \mathrm{L}$ da amostra para um poço e adição de $180 \mu \mathrm{L}$ do reagente Cell Cycle ${ }^{\circledR}$ para atingir $1 \times 10^{6}$ parasitas $/ \mathrm{mL}$. A leitura foi realizada após incubação por 30 minutos no equipamento citômetro de fluxo Guava EasyCyte ${ }^{\mathrm{TM}} 8 \mathrm{HT}$. 


\section{Resultados e discussão}

\subsection{Estudo de replicação dos parasitos}

O primeiro ensaio realizado foi o estabelecimento da curva de crescimento do parasito em meio de cultura, realizado em duplicata em dois ensaios distintos, para observar quanto tempo levaria para atingir a fase de crescimento logarítmico e a sua duração. Pode-se observar na Figura 12 que, para o T. cruzi, o parasito passa da fase estacionária inicial (lag) para a fase logarítmica (log) a partir do quinto dia e esta fase dura uma semana.

Figura 12. Curva de crescimento da forma epimastigota do T. cruzi (cepa Y) estabelecida pela contagem na câmara de Neubauer.

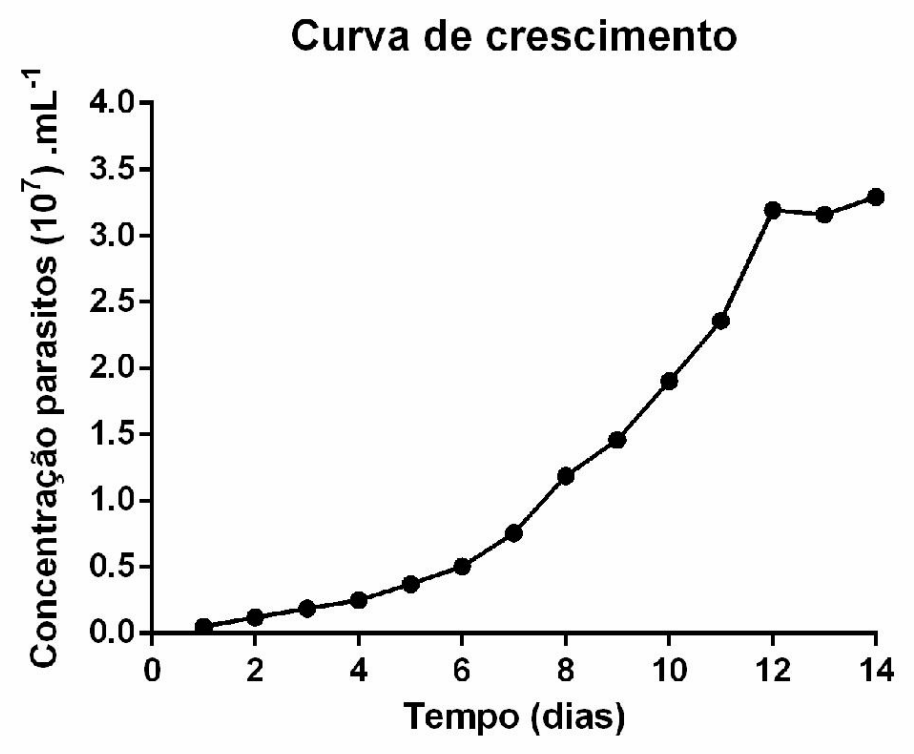

Para L. amazonensis foram realizados dois ensaios em concentrações de $1 \times 10^{6}$ parasitos $/ \mathrm{mL}$ e $1 \times 10^{5}$ parasitos $/ \mathrm{mL}$. Na maior concentração inicial, a fase estacionária logarítmica (log) iniciou-se após $24 \mathrm{~h}$ e durou até $72 \mathrm{~h}$ (Figura 13). As análises foram realizadas em duplicatas em dois ensaios distintos.

Para demonstrar que o crescimento depende da concentração inicial inoculada, foi realizado o ensaio com a concentração inicial de $1 \times 10^{5}$ parasitos $/ \mathrm{mL}$. O resultado nos mostrou que, com uma concentração dez vezes menor, o parasita demora o dobro 
do tempo para iniciar a fase logarítmica, que está entre 72 e 120 horas, ou seja, uma concentração inicial diferente inoculada nos dá uma resposta diferente (Figura 14).

Figura 13. Curva de crescimento da forma promastigota de $L$ amazonensis com duas concentrações iniciais de $1 \times 10^{6}$ células $/ \mathrm{mL}$ e $1 \times 10^{5}$ células $/ \mathrm{mL}$

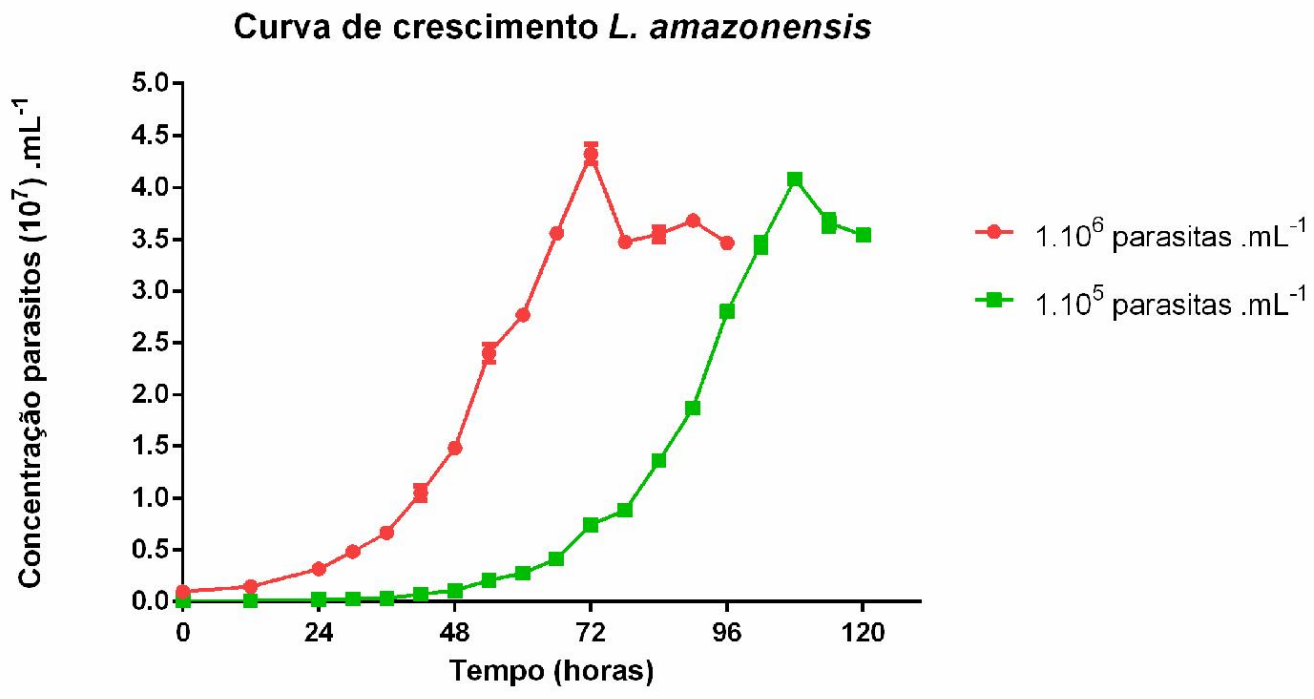

O mesmo experimento foi realizado para a L. chagasi, sem alterações em relação aos dados obtidos para a $L$. amazonensis, conforme pode ser visto na Fig. 14 . As análises foram realizadas em duplicatas em dois ensaios distintos. 
Figura 14. Curva de crescimento da forma promastigota de L. chagasi com duas concentrações iniciais de $1 \times 10^{6}$ células $/ \mathrm{mL}$ e $1 \times 10^{5}$ células $/ \mathrm{mL}$

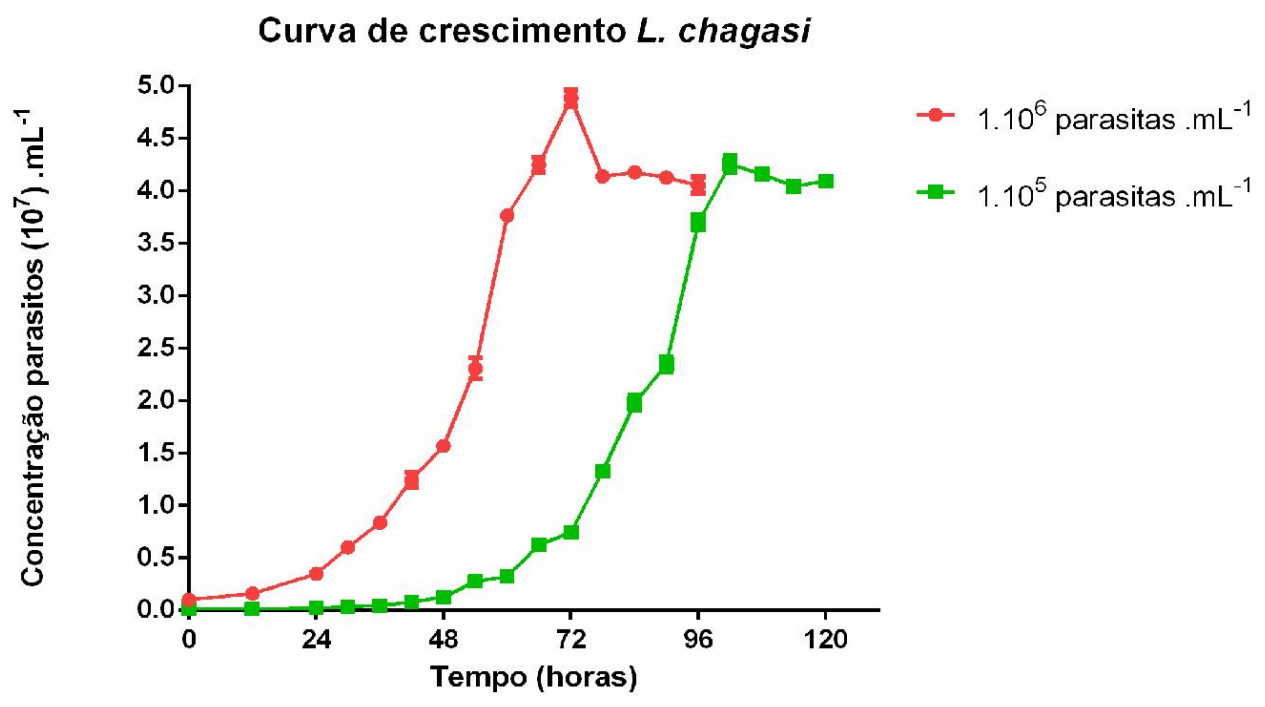

\subsection{Padronização do método colorimétrico}

O primeiro problema a ser enfrentado no método colorimétrico é a solubilização dos cristais de formazan, formados ao final do experimento, devido a insolubilidade em água. Os dados extraídos de estudos previamente publicados ${ }^{31,97-100}$ demonstraram que nenhum dos procedimentos descritos foi adequado para os estudos realizados, sendo necessário fazer uma investigação das condições adequadas. Portanto, houve uma variação na concentração (de $100 \%$ a $60 \%$ v/v) de agente solubilizante (solução 10\% SDS, água destilada e 0,01 N ácido clorídrico), porém apenas essa solução não solubilizava os cristais de formazan completamente. Tendo em vista que seria necessário adicionar um solvente orgânico para solubilizar completamente os cristais, o DMSO foi usado em concentrações crescentes de 0 a $40 \%$ (v/v). A concentração de $50 \%$ (v/v) de cada solução não foi otimizada pois foi observado em um teste que nessa proporção havia formação de outros cristais, tornando inviável a leitura. O ensaio foi realizado em sextuplicata em dois experimentos distintos.

Para chegar em um resultado inicial sobre a solubilização, imagens foram obtidas através de microscopia de campo claro dos cristais nos diferentes tempos e 
nos diferentes agentes solubilizantes, sendo que a total solubilização dos cristais foi obtida em 90 min na proporção 70/30 HCl/DMSO (Fig. 15). Dentre todas as proporções testadas, a solução com $70 \% \mathrm{HCl}$ e $30 \%$ DMSO apresentou melhores resultados em todos os períodos de tempo analisados.

Após a adição das diferentes proporções de agente solubilizante e DMSO, o tempo de incubação foi estudado. Leituras das placas foram realizadas em intervalos de incubação de 30 minutos, até completar 180 minutos (Fig. 16). No geral, as diferentes concentrações de agente solubilizante e DMSO não são tão relevantes para a absorbância, pois o resultado é semelhante, com o patamar de 0,7 de absorbância. No entanto, como os cristais de formazan foram solubilizados em 90 min na proporção 70/30 HCl/DMSO, esta condição foi considerada ótima e foi usada para os demais experimentos. 
Figura 15. Solubilização dos cristais de formazan a partir de diferentes proporções de agente solubilizante e DMSO e tempos de incubação para T. cruzi.

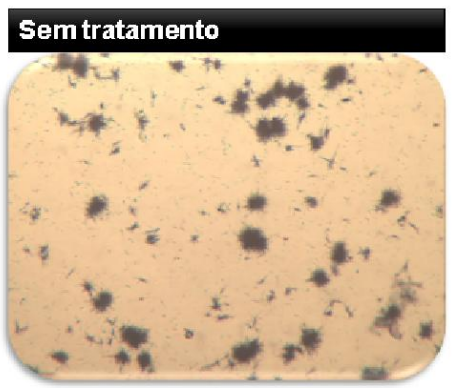

\section{$100 \%$ Agente Solubilizante}

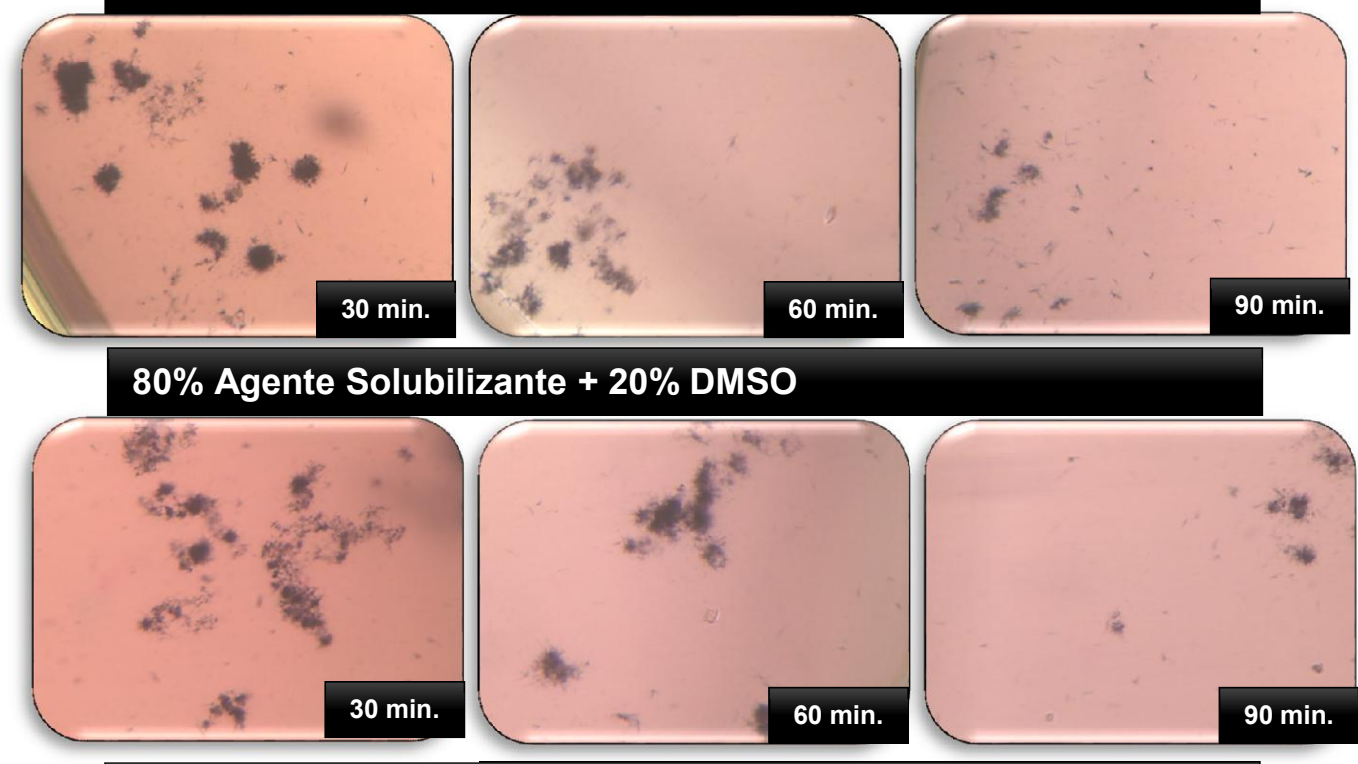

$70 \%$ Agente Solubilizante $+30 \%$ DMSO

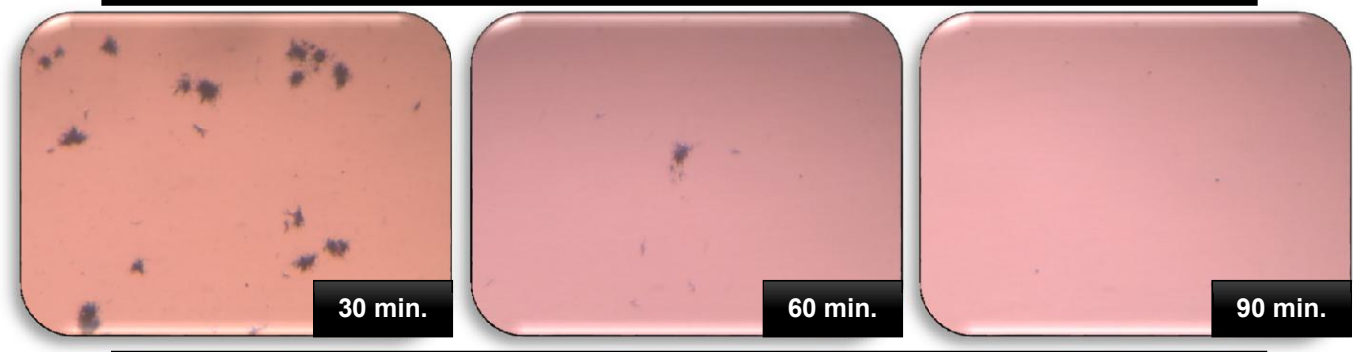

$60 \%$ Agente Solubilizante $+40 \%$ DMSO

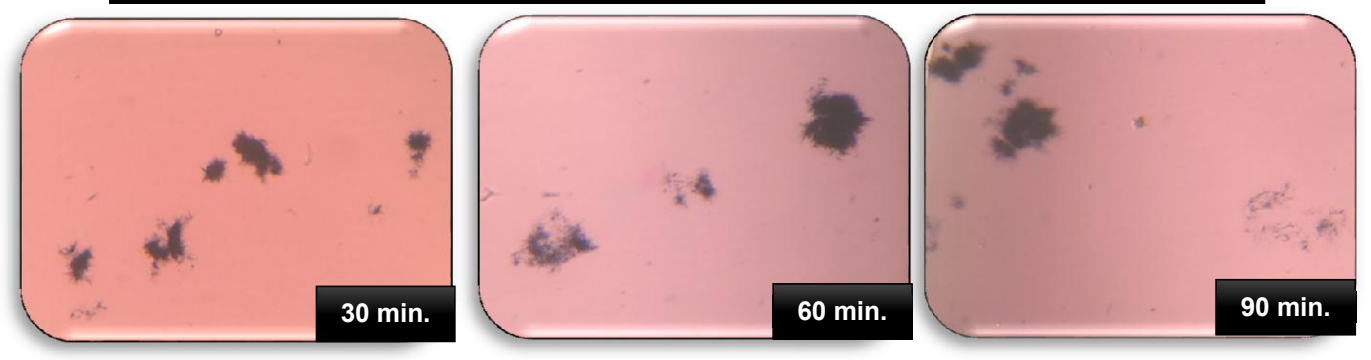




\section{T.cruzi cepa $Y$}

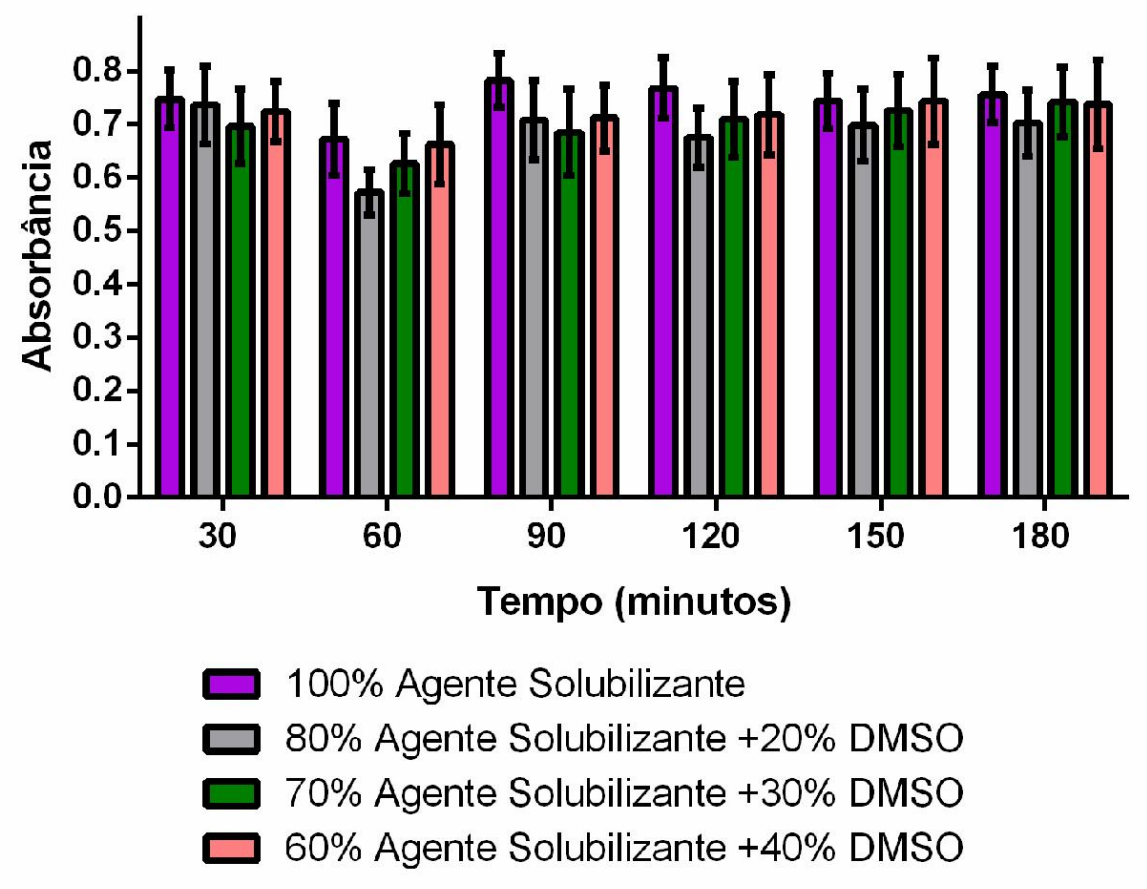

A próxima etapa de padronização do experimento foi baseada na comparação do método colorimétrico por MTT com a contagem na câmara de Neubauer, realizados em duplicata em dois ensaios distintos (Fig. 17). As regressões lineares foram estabelecidas, demonstrando que o ensaio colorimétrico apresenta uma faixa de linearidade bem considerável (Tabela 1). $O$ erro apresentado no método colorimétrico é equiparável ao método clássico de contagem usando a câmara de Neubauer, que é um método demorado e depende muito do observador, assim o método MTT pode ser aplicado para a triagem de moléculas bioativas.

A concentração otimizada para a triagem de compostos foi de $1 \times 10^{7}$ parasitas $/ \mathrm{mL}$, pois observamos que é uma concentração que se apresenta na fase log e os dados do ensaio estão de acordo com os ensaios descritos na literatura. Além de mostrar que o ensaio colorimétrico está diretamente correlacionado com o método tradicional, é observado na Fig. 16 que esta concentração é a mais adequada para a realização dos ensaios, com incubação do MTT por quatro horas, pois não há diferença significativa em relação a cinco horas de incubação. Estes ensaios foram realizados em sextuplicata em dois experimentos distintos. 
Figura 17. Regressão linear demonstrando a correlação existente entre o método colorimétrico de MTT e a concentração dos parasitos por contagem na câmara de Neubauer para forma epimastigota da cepa $\mathrm{Y}$ do T. cruzi.

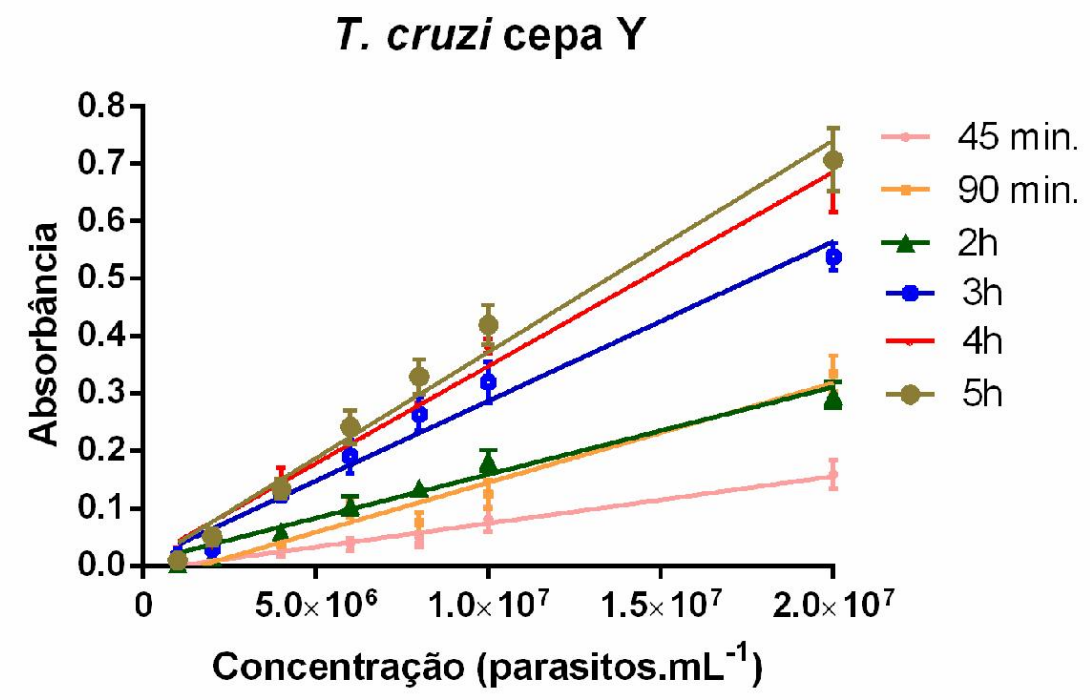

Tabela 1. Parâmetros estatísticos das regressões lineares da correlação entre o método colorimétrico (MTT) e a contagem na câmara de Neubauer para o T. cruzi.

\begin{tabular}{ccccccc}
\hline $\begin{array}{c}\text { Parâmetros } \\
\text { estatísticos }\end{array}$ & $\mathbf{4 5} \mathbf{~ m i n .}$ & $\mathbf{9 0} \mathbf{~ m i n .}$ & $\mathbf{2 ~ h}$ & $\mathbf{3 ~ h}$ & $\mathbf{4 h}$ & $\mathbf{5 ~ h}$ \\
\hline$r^{2}$ & 0,918 & 0,929 & 0,948 & 0,960 & 0,974 & 0,964 \\
Sy.x & 0,0155 & 0,0296 & 0,0214 & 0,0350 & 0,0335 & 0,0431 \\
$F$ & 529 & 571 & 797 & 1163 & 1994 & 1367 \\
$p$ & $<0,0001$ & $<0,0001$ & $<0,0001$ & $<0,0001$ & $<0,0001$ & $<0,0001$ \\
& $8,18 \times 10^{-9}\left( \pm 3,56 \times 10^{-10}\right) \times$ & $1,73 \times 10^{-8}\left( \pm 7,24 \times 10^{-10}\right) \times 1,52 \times 10^{-8}\left( \pm 5,38 \times 10^{-10}\right) \times 2,78 \times 10^{-8}\left( \pm 8,14 \times 10^{-10}\right) \times 3,38 \times 10^{-8}\left( \pm 7,57 \times 10^{-10}\right) \times 3,69 \times 10^{-8}\left( \pm 9,98 \times 10^{-10}\right) \times$ \\
Equação & $-7,65 \times 10^{-3}\left( \pm 3,46 \times 10^{-3}\right)$ & $-2,79 \times 10^{-2}\left( \pm 7,42 \times 10^{-3}\right)$ & $+7,45 \times 10^{-3}\left( \pm 5,58 \times 10^{-3}\right)$ & $+9,08 \times 10^{-3}\left( \pm 7,96 \times 10^{-3}\right)$ & $+9,12 \times 10^{-3}\left( \pm 7,20 \times 10^{-3}\right)$ & $+2,83 \times 10^{-3}\left( \pm 9,66 \times 10^{-3}\right)$
\end{tabular}

Os valores estatísticos das regressões são adequados (Tabela 1):

- $r^{2}$ representa o coeficiente da regressão linear e quanto mais o valor se aproxima de 1, significa que o ajuste ao modelo estão adequados, sendo que em todos os casos os seus valores são considerados altos para um ensaio celular;

- Sy.x representa os desvios dos pontos em relação à absorbância, com valores baixos em todos os estudos. Fazendo-se uma análise em relação às absorbâncias, estes valores são proporcionalmente ainda menores para os períodos de incubação de 4 e 5 h; 
- F é o "coeficiente de Fischer" e mostra quão distante estão os pontos entre si, ou seja, quanto maior o valor de $F$, mais os pontos estão dispersos no eixo. No estudo os valores estão altos para todos os tempos de incubação, especialmente para os que possuem maior tempo de incubação;

- Todas as análises apresentam validade estatística a partir do baixíssimo valor de corte para $p$.

Posteriormente o detergente extran foi testado no $T$. cruzi, pois essa substância causa a desestruturação da membrana e leva o parasito a morte. Os ensaios foram realizados com incubações de soluções de extran em água por 4 e $24 \mathrm{~h}$ para (i) observar a atividade deste controle positivo para morte celular; e (ii) analisar se o método colorimétrico teria uma resposta equivalente ao estudo de contagem na câmara de Neubauer quando uma substância bioativa leva a morte parasitária (Figura 18). Os ensaios foram efetuados em quadruplicata (para o MTT) e duplicata (para a contagem na câmara de Neubauer) em dois experimentos distintos.

Figura 18. Viabilidade do T. cruzi após a incubação com o extran durante a) 4 h e b) 24 h.

(a)

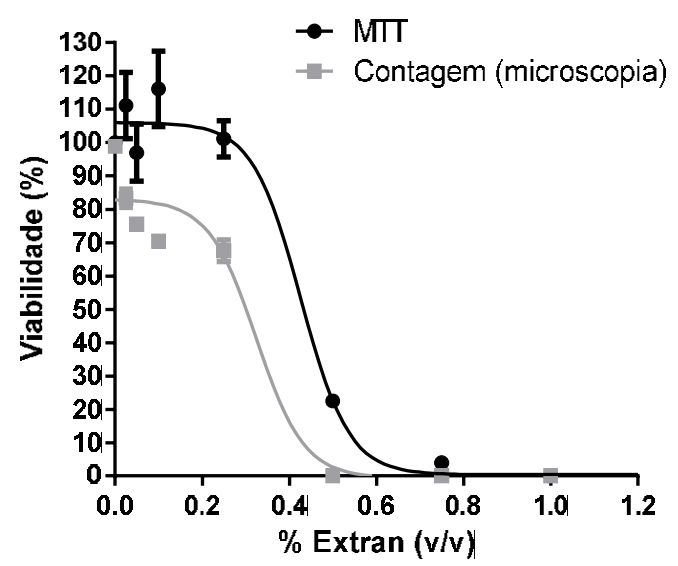

(b)

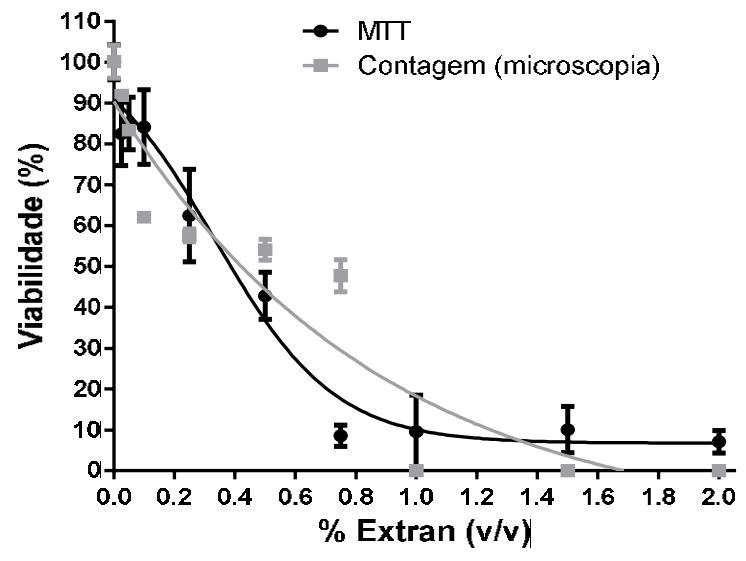


Tabela 2. Parâmetros estatísticos das curvas concentração-resposta do detergente extran.

\begin{tabular}{c|cc|cc}
\hline & \multicolumn{2}{|c|}{ 4 horas } & \multicolumn{2}{c}{24 horas } \\
\hline \multirow{3}{*}{ MTT } & $\mathrm{r}^{2}$ & Sy.x & $\mathrm{r}^{2}$ & Sy.x \\
Contagem & 0,976 & 8,20 & 0,947 & 8,45 \\
& 0,972 & 7,55 & 0,904 & 12,57 \\
\hline
\end{tabular}

É interessante notar que os resultados para $24 \mathrm{~h}$ de incubação apresentam maiores distorções em relação a 4 h, inclusive com maior desvio (Fig. 18, Tabela 2). Isto pode se dever a rápida ação surfactante do extran na célula, mas outras questões também podem estar interferindo no resultado, como a presença dos restos celulares e sua degradação. Os valores de EC $_{50}$ para o ensaio de 4 horas são: $0,43 \pm 0,02 \%$ (MTT) e 0,33 \pm 0,03\% (contagem por microscopia); e para 24 horas: $0,34 \pm 0,05 \%$

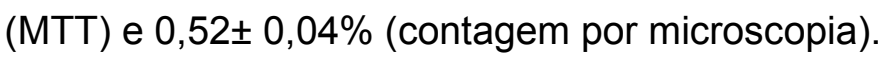

A etapa final de padronização do método e confirmação dos resultados foi realizada com o benzonidazol, que é o fármaco de referência para as triagens usando o $T$. cruzi. O ensaio foi realizado por 5 dias $^{6}$, com a resposta biológica sendo acompanhada diariamente, tanto pelo método colorimétrico, quanto pela contagem microscópica (Fig. 19). A concentração do benzonidazol variou de 0,0316 a 500 $\mu \mathrm{mol} / \mathrm{L}$, diluído com $0,5 \%$ de DMSO em meio de cultura. Em todos os testes, $0,5 \%$ de DMSO não afetou os resultados.

Os parâmetros da regressão linear estão adequados em todos os dias de ensaio, conforme visualizado na Tabela 3. A potência do benzonidazol vai aumentando a cada dia, até alcançar um platô no quarto e no quinto dia. Desta forma, não são necessárias novas análises com maior tempo de incubação, já que o composto tem praticamente a mesma potência no quarto e no quinto dia. Todos os ensaios para o método colorimétrico foram realizados em sextuplicata em dois experimentos independentes $(n=12)$, enquanto que as contagens dos parasitos foram realizadas em duplicata em dois ensaios independentes $(n=4)$. 
Figura 19. Triagem usando a forma epimastigota da cepa Y do T. cruzi com incubação do benzonidazol por 5 dias.
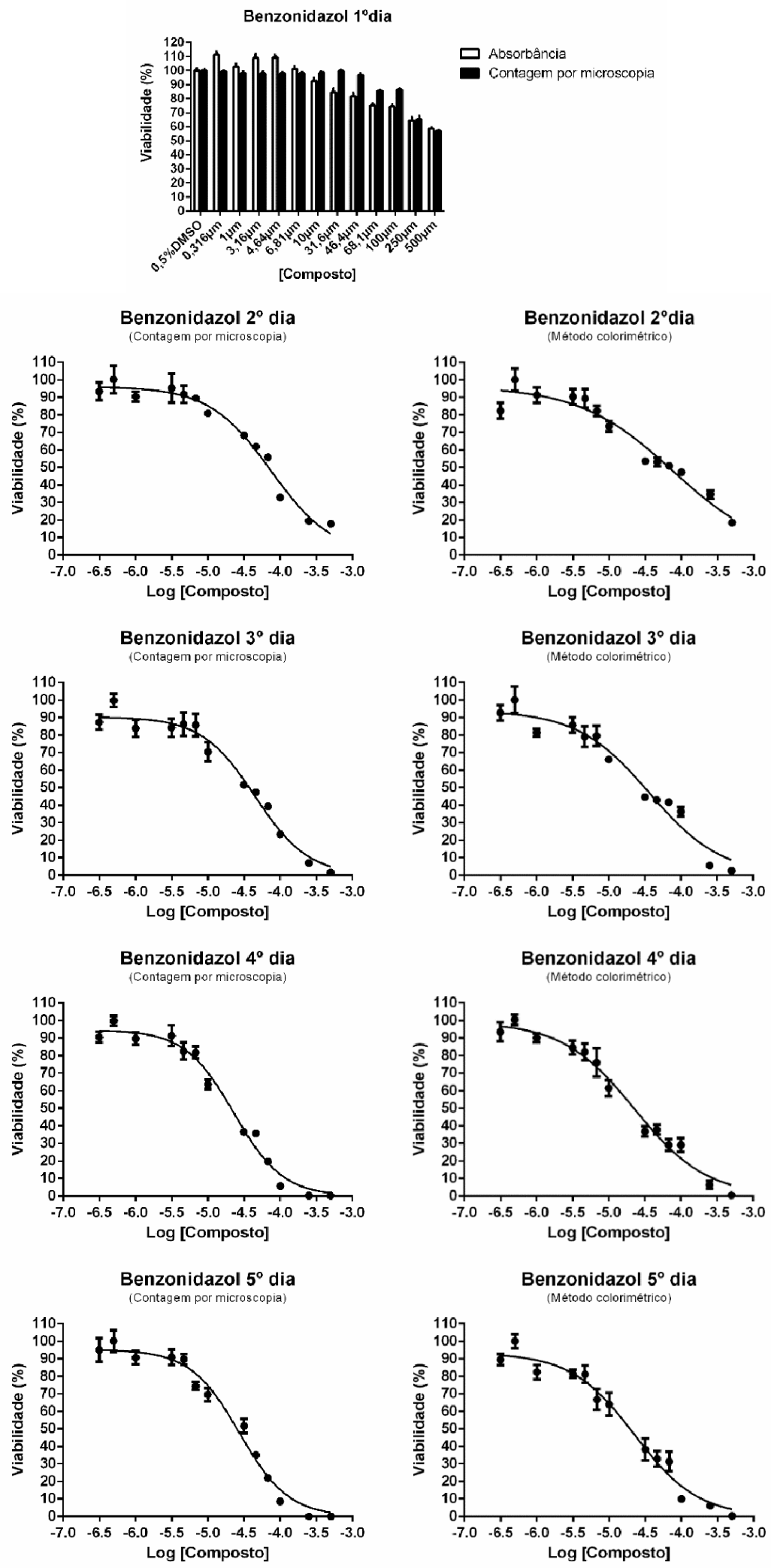
Tabela 3. Parâmetros estatísticos das triagens usando a forma epimastigota da cepa $\mathrm{Y}$ do $T$. cruzi com incubação do benzonidazol por 5 dias.

\begin{tabular}{l|ccc}
\hline & $r^{2}$ & Sy.x & EC $_{50}$ \\
\hline \multirow{2}{*}{ MTT } & \multicolumn{3}{c}{$2^{\circ}$ dia } \\
Contagem & 0,933 & 6,40 & $75,26 \pm 6,56 \mu \mathrm{M}$ \\
\hline \multirow{2}{*}{ MTT } & 0,966 & 5,45 & $74,69 \pm 5,05 \mu \mathrm{M}$ \\
Contagem & 0,949 & $3^{\circ}$ dia \\
\hline \multirow{3}{*}{ MTT } & 0,968 & 7,08 & $36,52 \pm 2,87 \mu \mathrm{M}$ \\
Contagem & 0,967 & 5,90 & $44,71 \pm 3,26 \mu \mathrm{M}$ \\
\hline \multirow{3}{*}{ MTT } & 0,980 & $4^{\circ}$ dia & \\
Contagem & 0,87 & $22,77 \pm 1,47 \mu \mathrm{M}$ \\
\hline
\end{tabular}

Os resultados de $\mathrm{EC}_{50}$ obtidos em ambos os ensaios com o composto de referência benzonidazol, são similares aqueles apresentados na literatura ${ }^{101}$.

As imagens por microscopia de campo claro confirmaram os resultados dos estudos colorimétricos (Fig. 20). As concentrações de benzonidazol abaixo de $10 \mu \mathrm{M}$ não levaram a alterações morfológicas do parasita no quinto dia. Porém quando observamos a concentração de $31,6 \mu \mathrm{M}$, que é um valor próximo do $\mathrm{EC}_{50}$, nota-se que alguns parasitas alteram a morfologia e começam a ficar arredondados. A quantidade de parasitas com a morfologia alterada aumenta de acordo com a concentração do benzonidazol, mostrando uma relação dependente da concentração administrada. 
Figura 20. Análise morfológica da forma epimastigota, cepa Y do T. cruzi, com incubação do benzonidazol no quinto dia de incubação.
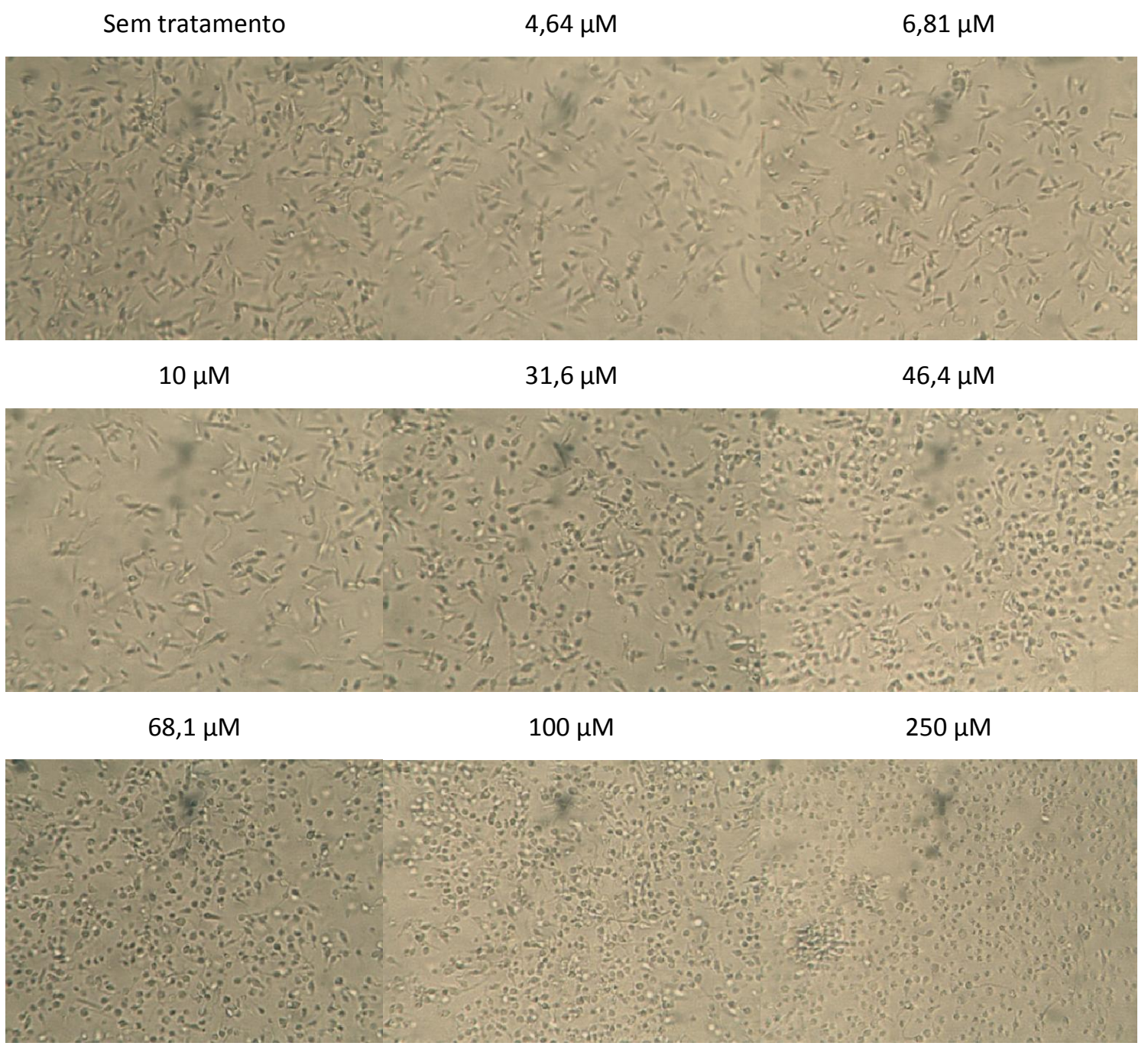

Novamente, a solubilização dos cristais de formazan foi um parâmetro essencial para observar se o procedimento usado para o T. cruzi também seria válido para as espécies de leishmania. Pode-se observar na Fig. 21 que as mesmas condições podem ser mantidas para L. chagasi, tanto em termos de tempo de exposição, quanto na composição do agente solubilizante. 
Figura 21. Solubilização dos cristais de formazan a partir de diferentes proporções de agente solubilizante e DMSO para L. chagasi.

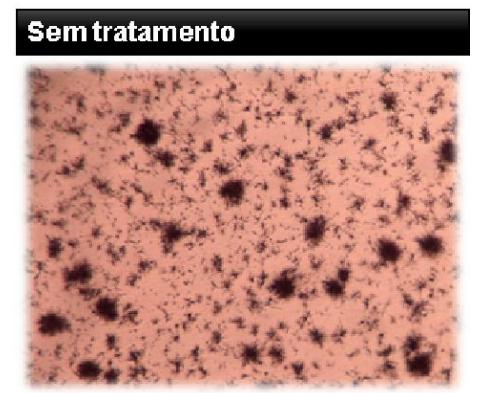

\section{$100 \%$ Agente Solubilizante}
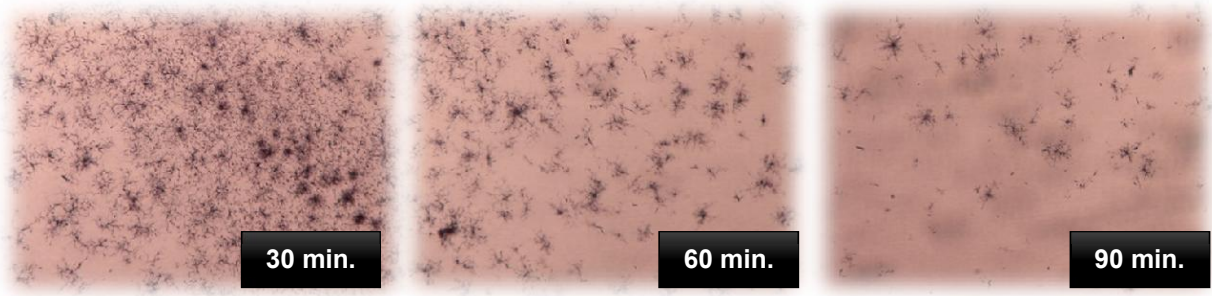

\section{$80 \%$ Agente Solubilizante $+20 \%$ DMSO}

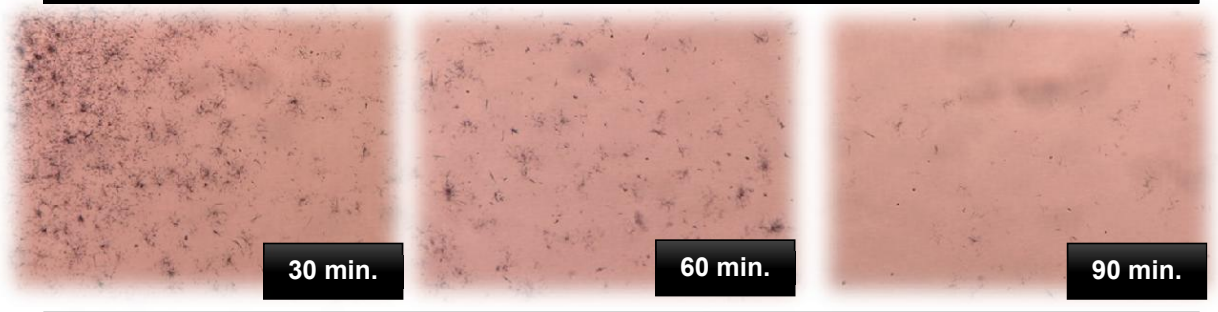

\section{$70 \%$ Agente Solubilizante + $30 \%$ DMSO}

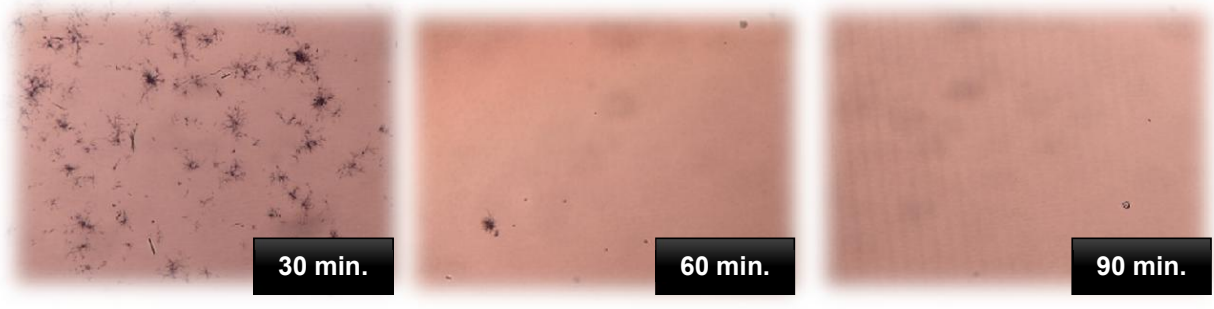

$60 \%$ Agente Solubilizante + $40 \%$ DMSO
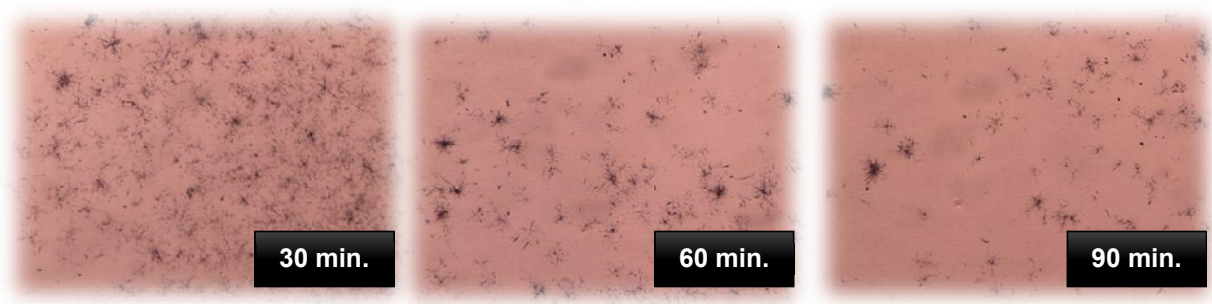
As regressões lineares foram realizadas para $L$. chagasi usando $1 \times 10^{7}$ parasitos $/ \mathrm{mL}$ e incubação do MTT durante $4 \mathrm{~h}$, com excelente resposta para o ensaio colorimétrico (Fig. 22 e Tabela 4). A resposta foi acentuada nas concentrações mais altas dos parasitos, demonstrando que o tempo de incubação afeta o metabolismo do MTT com o uso do PMS como carreador de elétrons.

Figura 22. Regressão linear demonstrando a correlação existente entre o método colorimétrico de MTT e a concentração dos parasitos por contagem na câmara de Neubauer para forma promastigota de L. chagasi.

\section{L. chagasi}

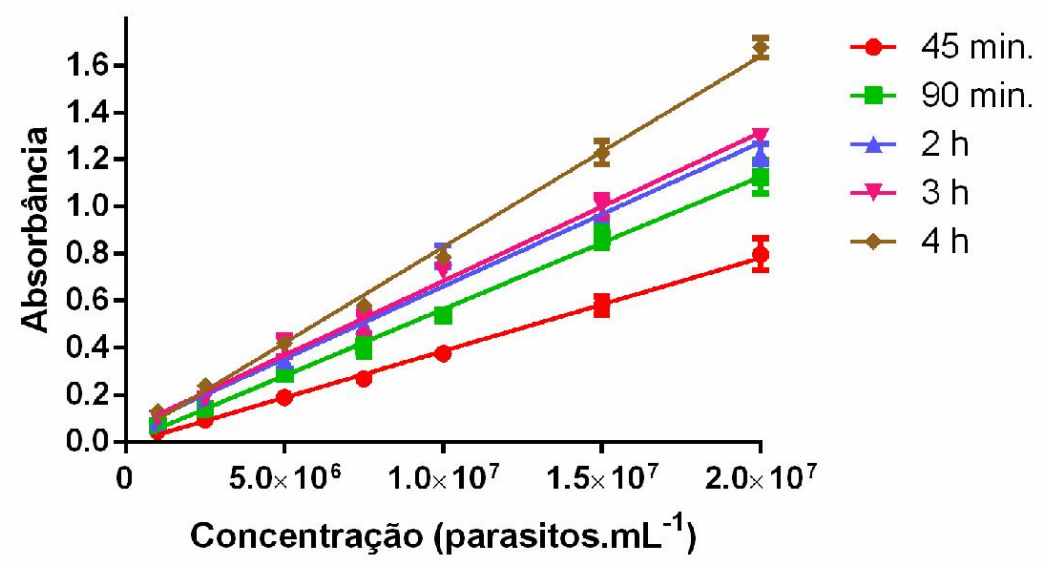

Tabela 4. Parâmetros estatísticos das regressões lineares da correlação entre o método colorimétrico (MTT) e a contagem na câmara de Neubauer para a L. chagasi.

\begin{tabular}{cccccc}
\hline $\begin{array}{c}\text { Parâmetros } \\
\text { estatísticos }\end{array}$ & $\mathbf{4 5} \mathbf{~ m i n . ~}$ & $\mathbf{9 0} \mathbf{~ m i n .}$ & $\mathbf{2 ~ h}$ & $\mathbf{3 ~ h}$ & $\mathbf{4 ~ h}$ \\
\hline$R^{2}$ & 0,984 & 0,989 & 0,976 & 0,989 & 0994 \\
$S y . x$ & 0,0323 & 0,0394 & 0,0628 & 0,0428 & 0,0423 \\
$F$ & 2520 & 3465 & 1612 & 3684 & 6258 \\
$p$ & $<0,0001$ & $<0,0001$ & $<0,0001$ & $<0,0001$ & $<0,0001$ \\
Equação & $3,95.10^{-8}\left( \pm 7,86 \times 10^{-10}\right) \times$ & $5,64 \times 10^{-8}\left( \pm 9,57 \times 10^{-10}\right) \times$ & $6,13 \times 10^{-8}\left( \pm 1,53 \times 10^{-9}\right) \times$ & $\left.6,31 \times 10^{-8} \pm \pm 1,04 \times 10^{-9}\right) \times$ & $8,13 \times 10^{-8}\left( \pm 1,03 \times 10^{-9}\right) \times$ \\
& $-7,97 \times 10^{-3}\left( \pm 8,48 \times 10^{-3}\right)$ & $-3,60 \times 10^{-5}\left( \pm 1,03 \times 10^{-2}\right)$ & $+4,75 \times 10^{-2}\left( \pm 1,64 \times 10^{-2}\right)$ & $+5,25 \times 10^{-2}\left( \pm 1,12 \times 10^{-2}\right)$ & $+1,44 \times 10^{-2}\left( \pm 1,11 \times 10^{-2}\right)$ \\
\hline
\end{tabular}

Novamente, os estudos colorimétricos não demonstraram variação na leitura de acordo com o tempo e composição do agente solubilizante (Fig. 22). No entanto, como no caso anterior, o mesmo tempo de incubação e composição do agente 
solubilizante foram determinados de acordo com a informação da solubilização dos cristais de formazan (ensaios em sextuplicata em dois experimentos distintos, $n=12$ ).

Figura 23. Ensaio colorimétrico para observar o efeito do agente solubilizante em $L$. chagasi

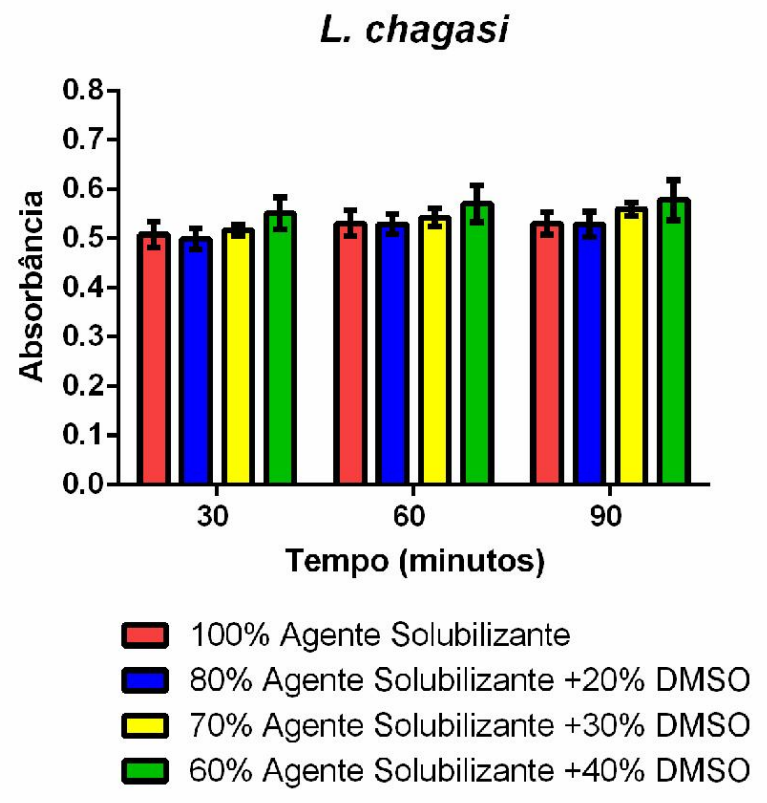

Para a L. chagasi, os ensaios com compostos são realizados por 3 dias de incubação, análise mais rápida do que com o $T$. cruzi. Este perfil está justificado através da curva de crescimento, ou seja, a replicação de ambas espécies de leishmania é mais rápida do que do tripanossoma.

Análises do composto de referência são importantes para termos um padrão e um comparativo nos ensaios com novos compostos. Por isso curvas concentraçãoresposta foram realizadas, utilizando várias concentrações de anfotericina $B$ durante 3 dias, para determinar a potência usando dois métodos distintos (colorimétrico por MTT e microscopia com câmara de Neubauer). No terceiro dia observa-se que a anfotericina apresenta maior eficácia, embora a potência tenha sido a mesma já determinada após o segundo dia de incubação (Fig. 24, Tabela 5). O valor de EC50 obtido no trabalho, está dentro dos valores já descrito na literatura com outras espécies ${ }^{102}$. Os ensaios foram realizados em sextuplicata em dois ensaios distintos para o MTT e em duplicata em dois ensaios distintos para a contagem usando a câmara de Neubauer. 
Figura 24. Ensaio de concentração-resposta com a anfotericina B para L. chagasi usando análise colorimétrica por MTT e quantificação por microscopia em câmara de Neubauer.
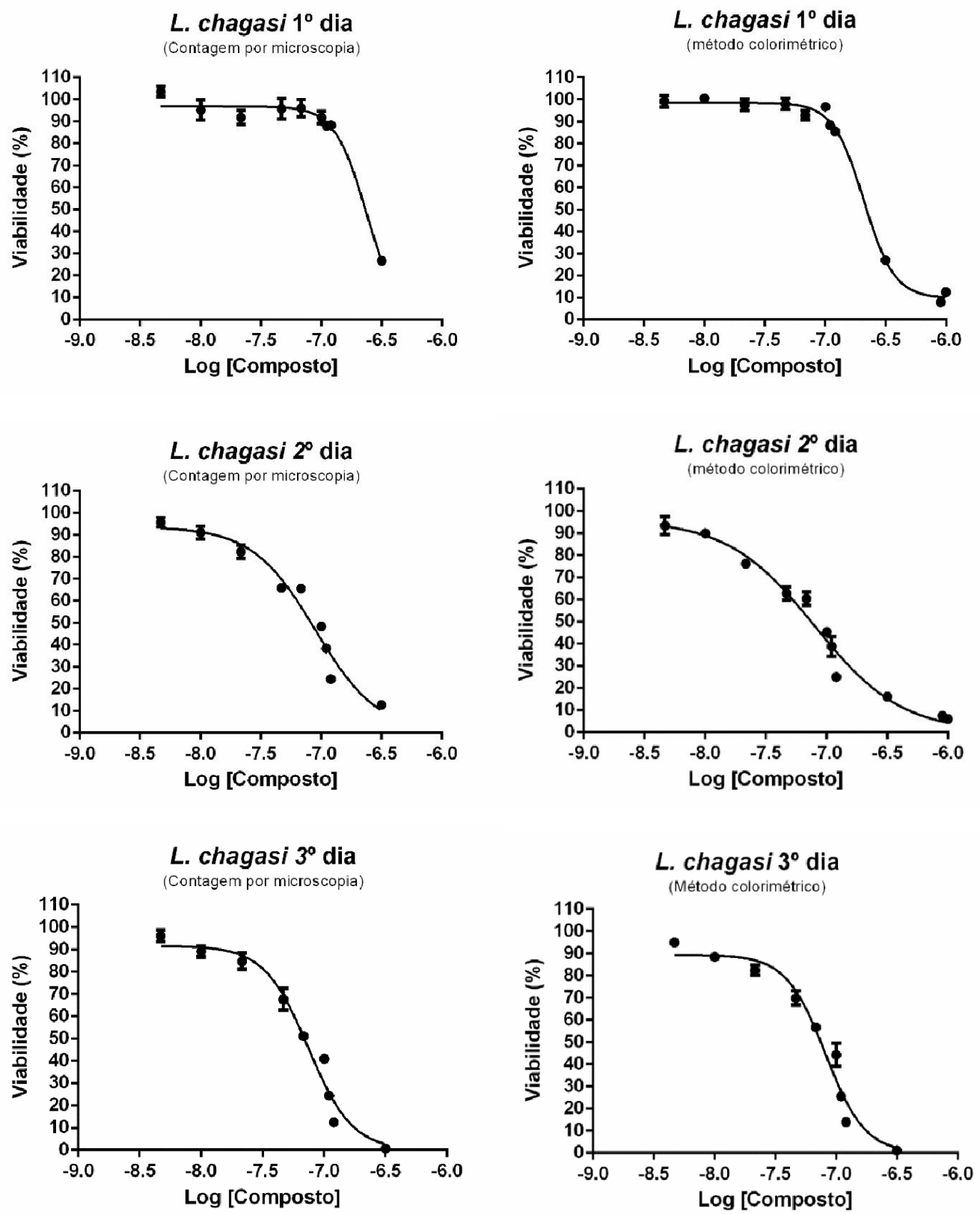
Tabela 5.Parâmetros estatísticos da curvas concentração-resposta da anfotericina B após incubação com a $L$. chagasi.

\begin{tabular}{l|ccc}
\hline \multirow{3}{*}{ MTT } & $r^{2}$ & Sy.x & $I_{50}$ \\
\cline { 2 - 4 } Contagem & \multicolumn{3}{|c}{$1^{\circ} \mathrm{dia}$} \\
\hline \multirow{2}{*}{ MTT } & 0,993 & 2,99 & $208,10 \pm 4,90 \mathrm{nM}$ \\
Contagem & 0,967 & 4,12 & $228,20 \pm 7,40 \mathrm{nM}$ \\
\hline \multirow{3}{*}{ MTT } & 0,972 & $2^{\circ} \mathrm{dia}$ \\
Contagem & 0,958 & 5,22 & $79,84 \pm 4,81 \mathrm{nM}$ \\
\hline
\end{tabular}

A L. amazonensis demonstrou possuir o mesmo perfil em relação a incubação e solubilização dos cristais de formazan em relação aos outros parasitos, demonstrando que o perfil físico-químico da amostra não alterou significativamente em cada experimento (Fig. 25). Este tipo de resultado pode remeter a estudos com outras cepas e espécies de parasitos visando observar se há uma propriedade comum para todos que poderá ser explorado em uma única condição de ensaio. Como nos outros casos, os ensaios foram realizados em sextuplicata em dois experimentos distintos.

É interessante notar que não houve alteração substancial na leitura de absorbância no método colorimétrico usando MTT, como também mencionado nos casos anteriores (Fig. 26), mesmo sendo observados cristais de formazan. Não se sabe exatamente porque o perfil de absorbância se manteve o mesmo, com baixos valores de desvio-padrão. No entanto, isto pode ser devido ao fato de que os cristais de formazan observados no microscópio estão uniformemente distribuídos, com um tamanho pequeno e não interferem no resultado final de absorbância, quando comparado ao maior caminho ótico realizado na amostra. 
Figura 25. Solubilização dos cristais de formazan a partir de diferentes proporções de agente solubilizante e DMSO e tempo de incubação para $L$. amazonensis.

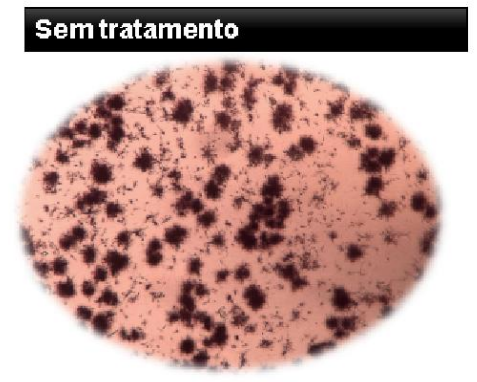

\section{$100 \%$ Agente Solubilizante}
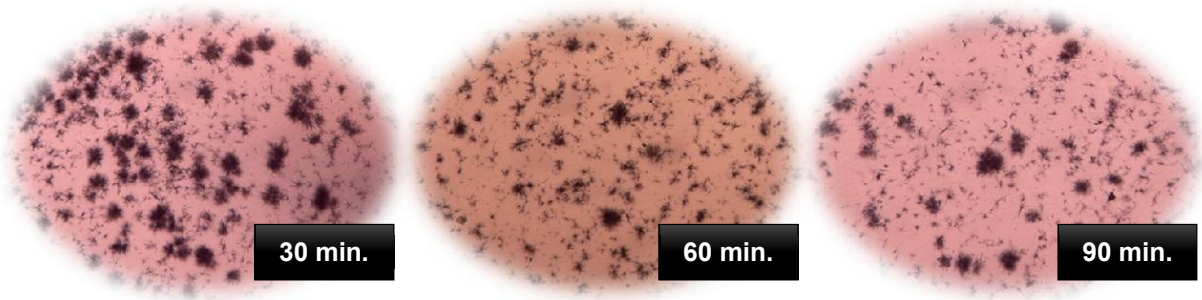

\section{$80 \%$ Agente Solubilizante $+20 \%$ DMSO}

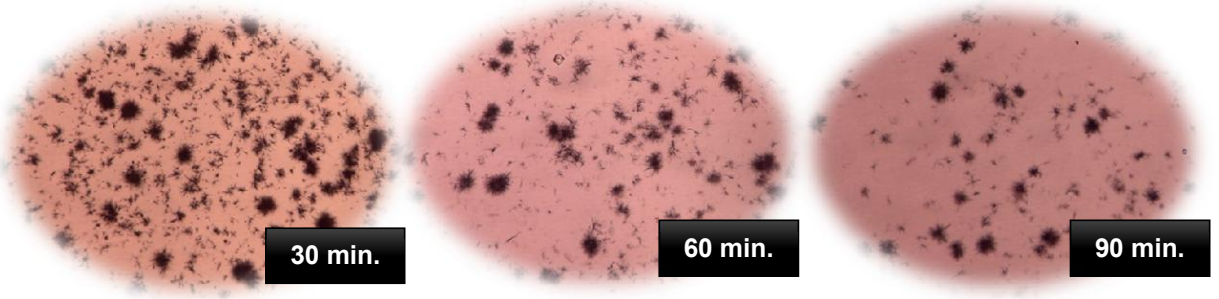

$70 \%$ Agente Solubilizante + $30 \%$ DMSO
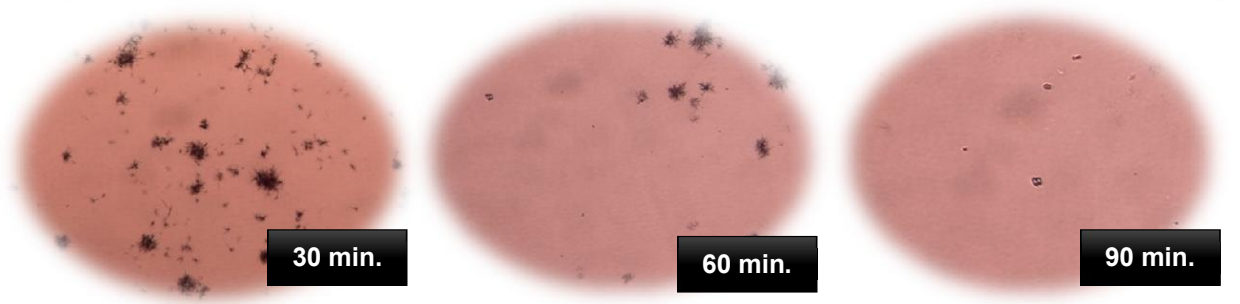

$60 \%$ Agente Solubilizante + 40\% DMSO
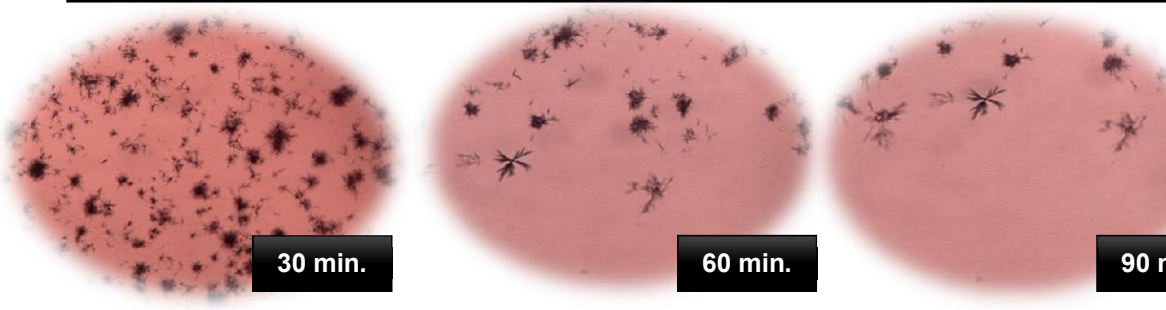

$60 \mathrm{~min}$

$90 \mathrm{~min}$. 
Figura 26. Ensaio colorimétrico para observar o efeito do agente solubilizante em L. amazonensis.

\section{L. amazonensis}

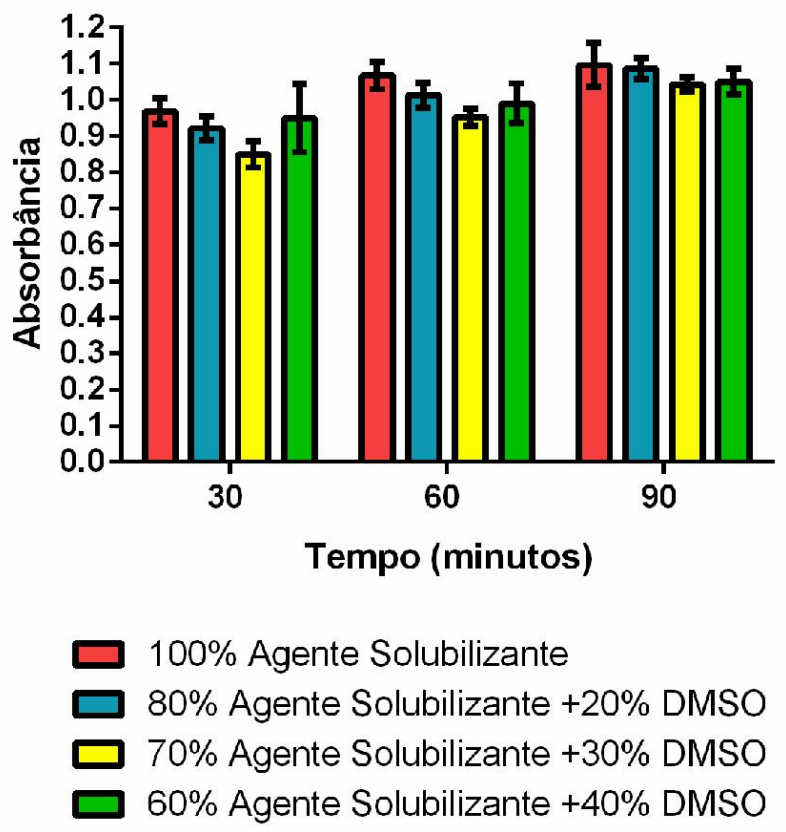

As regressões lineares foram realizadas para $L$. amazonensis (Fig. 27 e Tabela 6). Diferentemente dos outros casos, este parasito não apresentou diferença entre 3 e 4 horas de incubação. No entanto, para manter a mesma condição previamente estabelecida, o tempo de 4 horas foi mantido, juntamente com a concentração de $1 \times 10^{7}$ parasitos $/ \mathrm{mL}$.

Seguindo a padronização do experimento, a concentração-resposta foi realizada para a anfotericina $B$ na $L$. amazonensis com sextuplicatas em dois ensaios independentes, o qual obteve um valor de $\mathrm{EC}_{50}$ próximo do que está descrito na literatura com outras espécies ${ }^{102}$ (Fig. 28, Tabela 7). Desde o primeiro dia foi possível obter uma curva concentração-resposta, o que pode ser explicado devido a rápida curva de crescimento da Leishmania spp. que alcança o platô em apenas quatro dias, quando comparado com $T$. cruzi (uma semana). Deve-se notar que à medida que a anfotericina é incubada com a leishmania há um aumento na eficácia, sem alteração na potência. 
Figura 27. Regressão linear demonstrando a correlação existente entre o método colorimétrico de MTT e a concentração dos parasitos por contagem na câmara de Neubauer para forma promastigota de L. amazonensis.

\section{L. amazonensis}

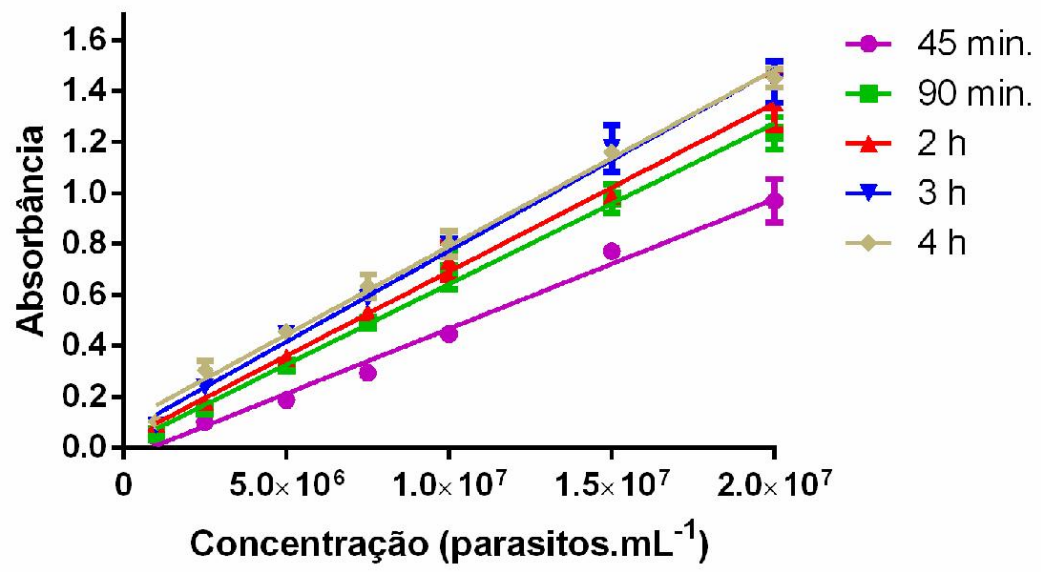

Tabela 6. Parâmetros estatísticos das regressões lineares da correlação entre o método colorimétrico (MTT) e a contagem na câmara de Neubauer para a Leishmania amazonensis.

\begin{tabular}{|c|c|c|c|c|c|}
\hline $\begin{array}{l}\text { Parâmetros } \\
\text { estatísticos }\end{array}$ & $45 \mathrm{~min}$. & $90 \mathrm{~min}$. & $2 \mathrm{~h}$ & $3 \mathrm{~h}$ & $4 \mathrm{~h}$ \\
\hline$R^{2}$ & 0.9803 & 0.9858 & 0.9851 & 0.9852 & 0.9898 \\
\hline Sy.x & 0.04688 & 0.04920 & 0.05279 & 0.05684 & 0.04584 \\
\hline$F$ & 1993 & 2779 & 2649 & 2655 & 3866 \\
\hline$p$ & $<0.0001$ & $<0.0001$ & $<0.0001$ & $<0.0001$ & $<0.0001$ \\
\hline Equação & $\begin{array}{l}5.09 \times 10^{-8}\left( \pm 1.14 \times 10^{-9}\right) \mathrm{X} \\
-4.15 \times 10^{-2}\left( \pm 1.23 \times 10^{-2}\right)\end{array}$ & $\begin{array}{l}6.31 \times 10^{-8}\left( \pm 1.20 \times 10^{-9}\right) \mathrm{X} \\
+1.16 \times 10^{-2}\left( \pm 1.29 \times 10^{-2}\right)\end{array}$ & $\begin{array}{l}6.61 \times 10^{-8}\left( \pm 1.28 \times 10^{-9}\right) \times \\
+3.05 \times 10^{-2}\left( \pm 1.38 \times 10^{-2}\right)\end{array}$ & $\begin{array}{r}7.12 \times 10^{-8}\left( \pm 1.38 \times 10^{-9}\right) \mathrm{X} \\
+6.02 \times 10^{-2}\left( \pm 1.49 \times 10^{-2}\right)\end{array}$ & $\begin{array}{l}6.93 \times 10^{-8}\left( \pm 1.12 \times 10^{-9}\right) X \\
+9.76 \times 10^{-2}\left( \pm 1.20 \times 10^{-2}\right)\end{array}$ \\
\hline
\end{tabular}


Figura 28. Ensaio de concentração-resposta com a anfotericina B para L. amazonensis usando análise colorimétrica por MTT e quantificação por microscopia em câmara de Neubauer.
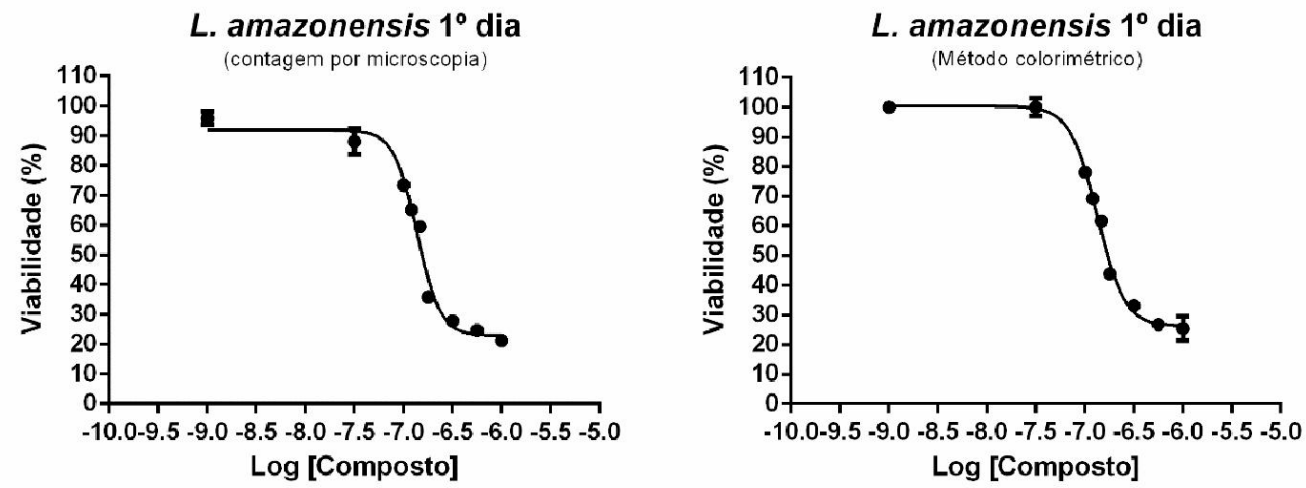

L. amazonensis $2^{\circ}$ dia

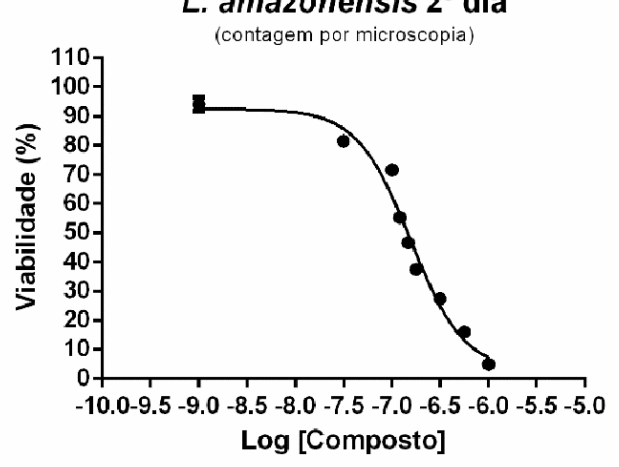

L. amazonensis $2^{\circ}$ dia

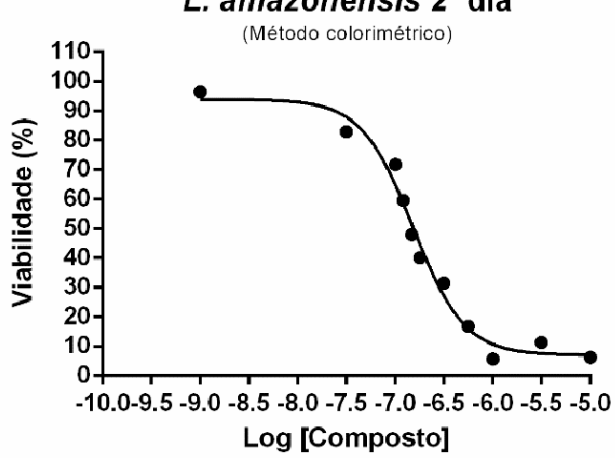

L. amazonensis $3^{\circ} \mathrm{dia}$
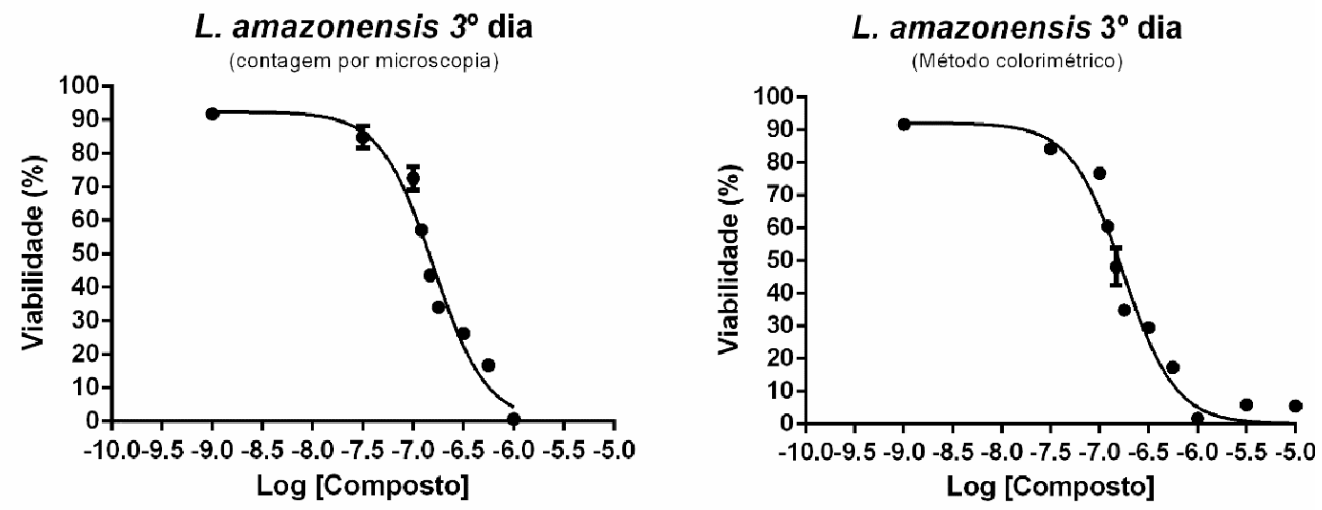
Tabela 7. Parâmetros estatísticos da anfotericina B para L. amazonensis

\begin{tabular}{l|ccc}
\hline & $r^{2}$ & Sy.x & EC 50 \\
\hline \multirow{3}{*}{ MTT } & \multicolumn{3}{c}{$1^{\circ} \mathrm{dia}$} \\
Contagem & 0,990 & 2,87 & $134 \pm 2,25 \mathrm{nM}$ \\
& 0,978 & 4,21 & $137 \pm 4,20 \mathrm{nM}$ \\
MTT & \multicolumn{3}{|c}{$2^{\circ}$ dia } \\
Contagem & 0,981 & 4,32 & $152 \pm 5,89 \mathrm{nM}$ \\
\hline \multirow{3}{*}{ MTT } & 0,996 & 4,64 & $156 \pm 11,2 \mathrm{nM}$ \\
Contagem & 0,963 & $3^{\circ}$ dia & $174 \pm 8,3 \mathrm{nM}$ \\
\hline
\end{tabular}

\subsection{Inibidores da Cruzaína}

Após a finalização da padronização dos experimentos usando o método colorimétrico por MTT, as triagens foram realizadas para cada classe de substâncias que atua nos alvos macromoleculares de interesse, sendo a primeira para os inibidores de cruzaína. A estratégia utilizada para o planejamento dessas novas moléculas bioativas, como descrito na literatura ${ }^{103}$, possui como função principal uma nitrila que se liga de forma covalente e reversível à enzima alvo. O ensaio fenotípico foi realizado com o T. cruzi, L. amazonensis e L. chagasi, pois todas possuem cisteíno proteases importantes para a manutenção dos parasitos.

A triagem inicial para três compostos demonstrou que os métodos de contagem e colorimétrico continuavam apresentando equivalência entre si (Neq0409, Neq0413, Neq0414, Fig. 29) demonstrando a robustez o método colorimétrico.

Nestes estudos de triagem, as substâncias são consideradas ativas quando causam inibição acima de $50 \%$ da replicação/viabilidade celular. As substâncias testadas não apresentaram atividade mesmo após 5 dias de incubação, excetuandose Neq0565, que diminuiu a viabilidade do parasito no valor de corte determinado anteriormente na concentração de $100 \mu \mathrm{M}$ (Fig. 29). 
Figura 29. Triagem de compostos inibidores de cisteíno proteases a $100 \mu \mathrm{M}$ na forma epimastigota do $T$. cruzi.

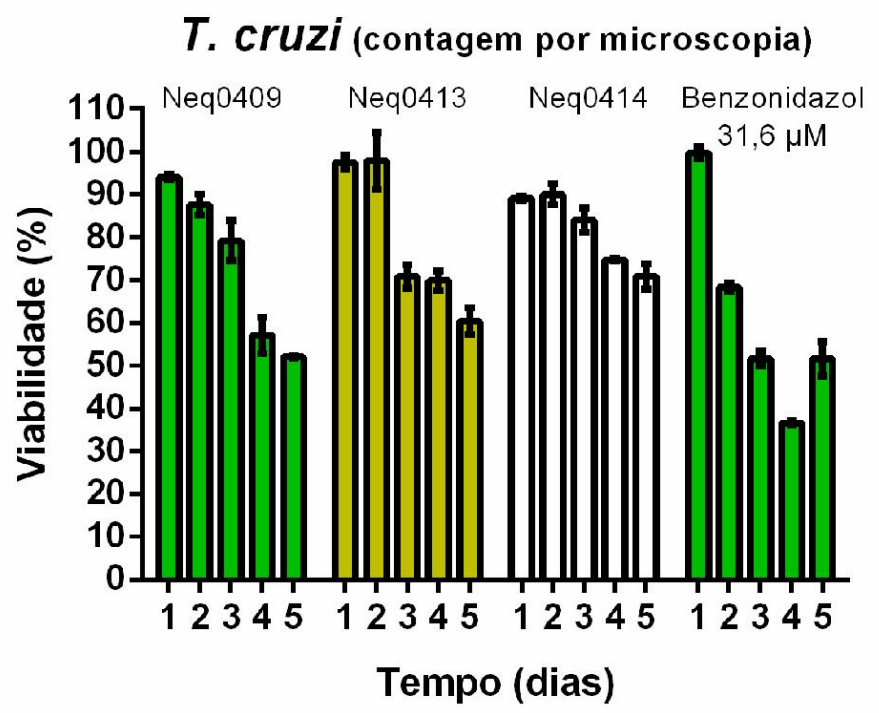

T. cruzi (método colorimétrico)

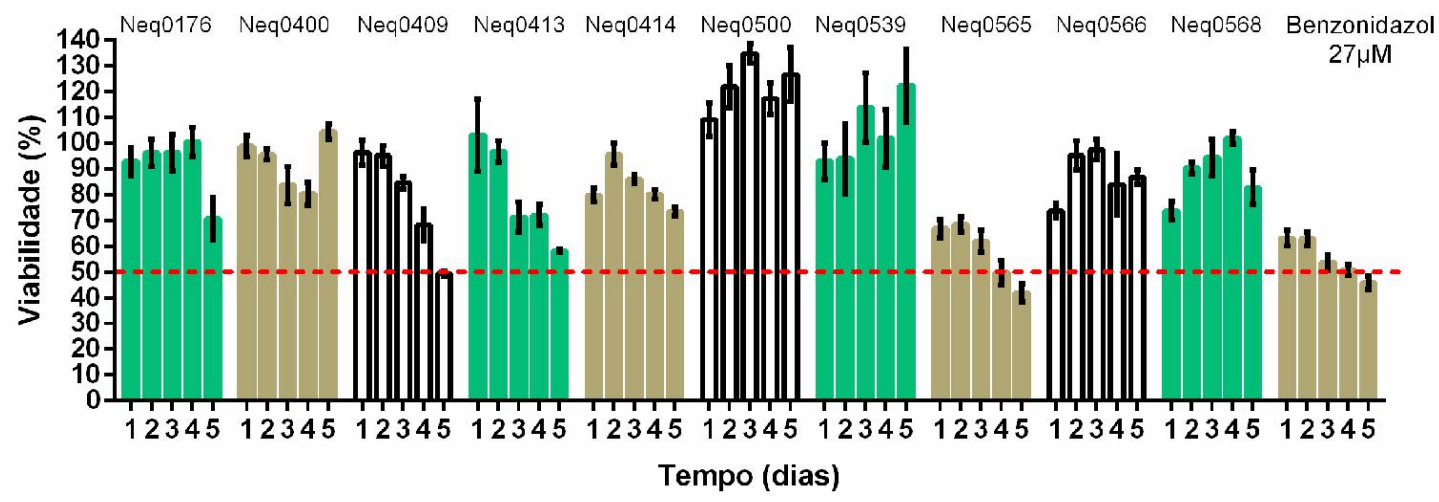

T. cruzi (método colorimétrico)

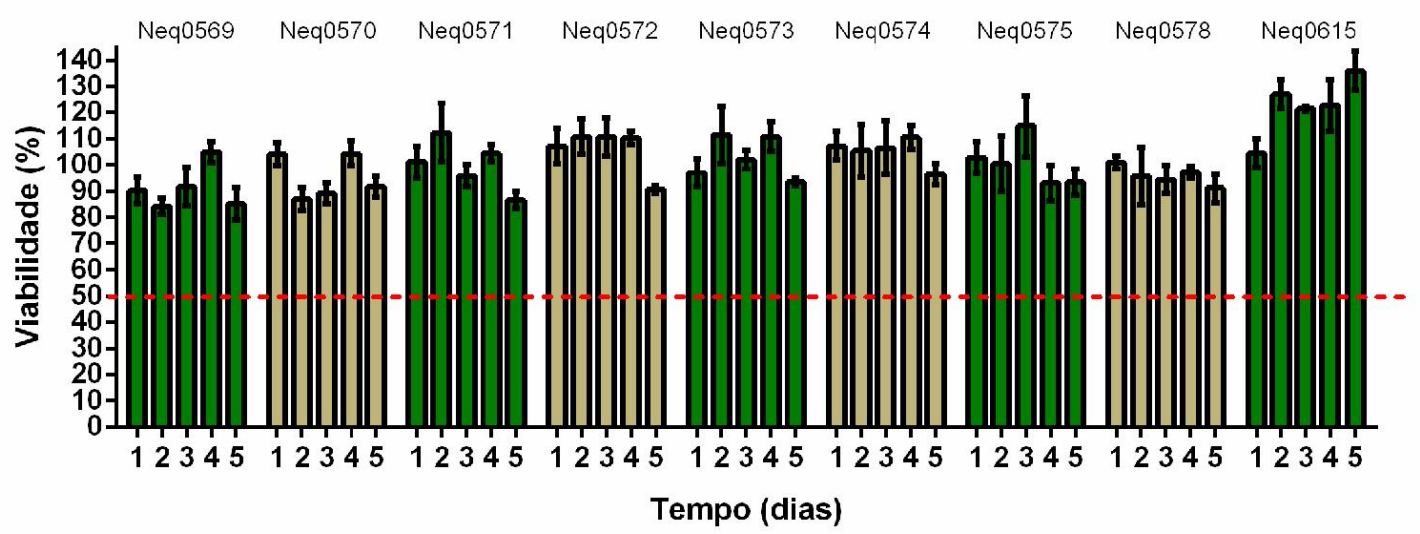

Substâncias como Neq0409 e Neq0413 apresentam boa potência nos ensaios de inibição da cruzaína. No entanto, esta não é trasladada para os ensaios celulares 
usando o $T$. cruzi. Não se sabe o que está ocorrendo nestes casos, mas faz-se necessário observar os parâmetros farmacocinéticos destas moléculas para poder realizar análises mais aprofundadas.

Neq0565 (S,S) e Neq0566 (R,S) são diastereômeros, conforme observado na Fig. 30. Esta diferença na estereoisomeria do carbono do aminoácido isoleucina leva a uma completa alteração no perfil farmacodinâmico das substâncias. Neq0565 é ativa contra a cruzaína, enquanto que Neq0566 não o é, sendo também observado o mesmo perfil nas triagens descritas anteriormente.

Figura 30. Relação estrutura-atividade para Neq0565 e Neq0566.
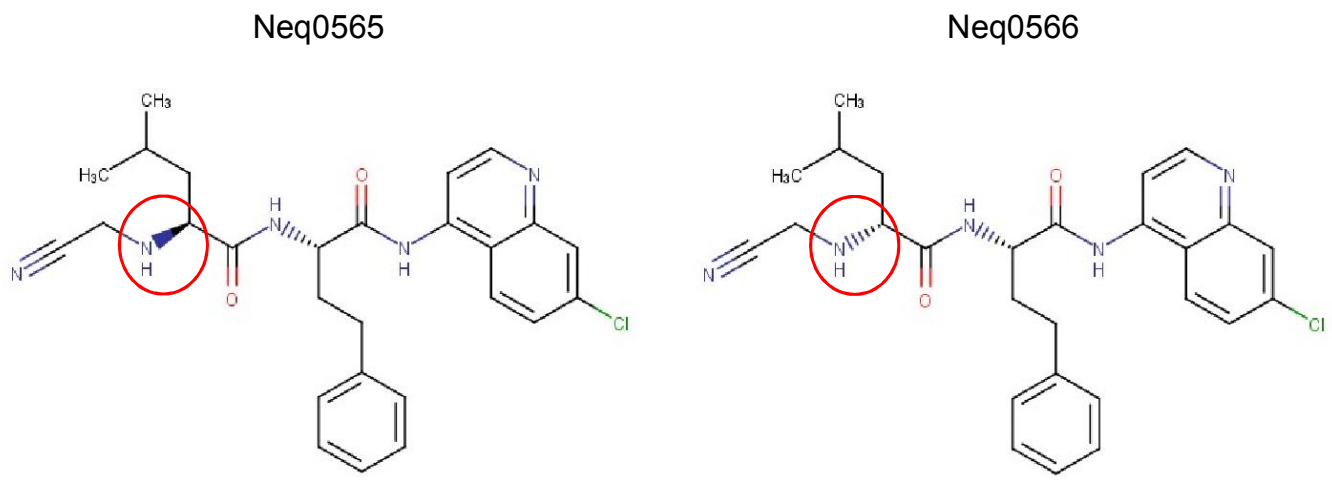

Não foi realizado qualquer tipo de seleção dos compostos para iniciar os testes com as espécies de leishmania, onde aquelas que ainda estavam presentes em estoque foram ensaiadas. No caso da leishmania, sabe-se que a cisteíno protease B (CPB) apresenta relevância para a viabilidade do parasito, embora não tenha uma descrição tão aprofundada quanto para a cruzaína. Desta forma, fez-se o ensaio de toda a série de inibidores de cisteíno proteases. As análises foram realizadas em quintuplicata em dois ensaios distintos, na concentração de $100 \mu \mathrm{mol} / \mathrm{L}$, com incubação por três dias, realizando análises a cada 24 horas.

O composto com melhor potência para esta parasitose foi o Neq0565, com inibição de $55 \%$ da viabilidade (Fig. 31). O mesmo que apresentou melhor atividade para o tripanossoma. 
Figura 31. Triagem de compostos inibidores de cisteíno proteases a $100 \mu \mathrm{M}$ na forma promastigota da $L$. chagasi.

\section{L. chagasi}

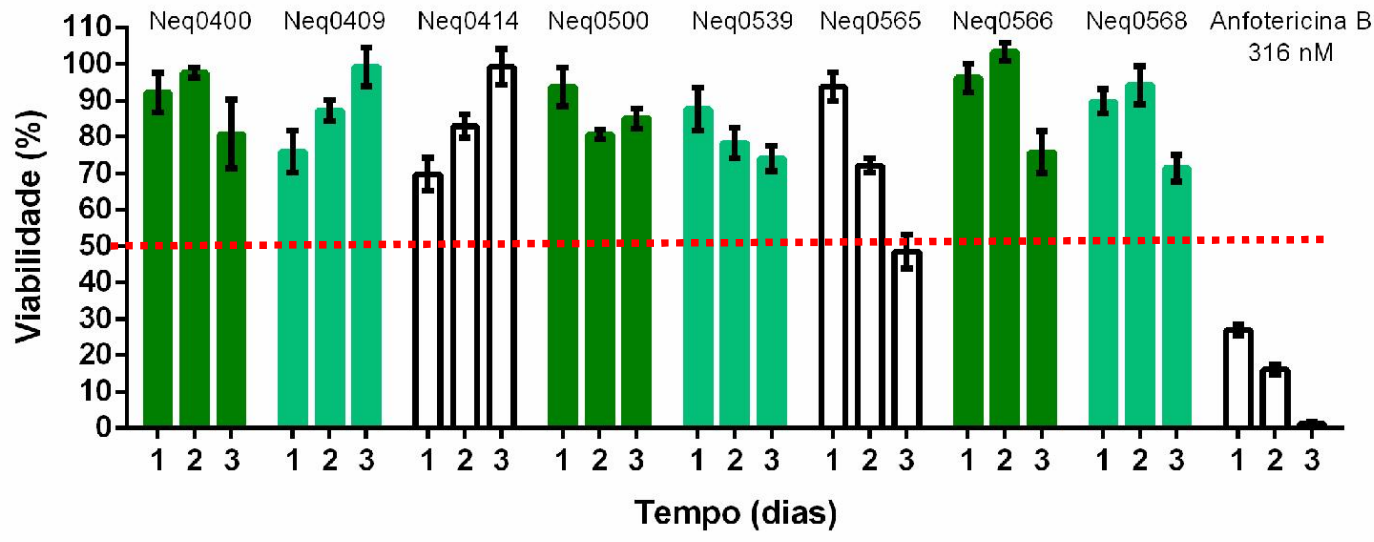

\section{L. chagasi}

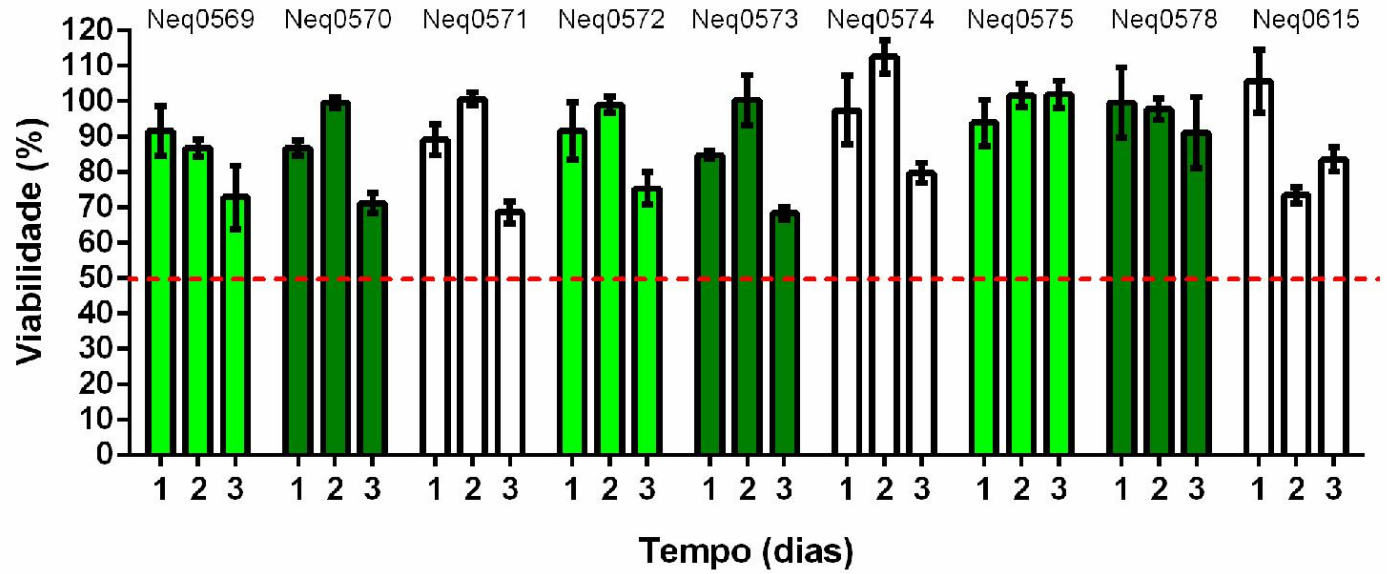

A triagem realizada para $L$. amazonensis demonstrou que, no geral, esta espécie apresenta um perfil diferente do que L. chagasi. Neq0539 foi a única substância bioativa da série (Fig 32) mas a inibição foi de apenas $50 \%$ da resposta na concentração testada. Neq0565 foi inativa, mostrando que há uma seletividade entre as espécies de leishmania. 
Figura 32. Triagem de compostos inibidores de cisteíno proteases a $100 \mu \mathrm{M}$ na forma promastigota da $L$. amazonensis

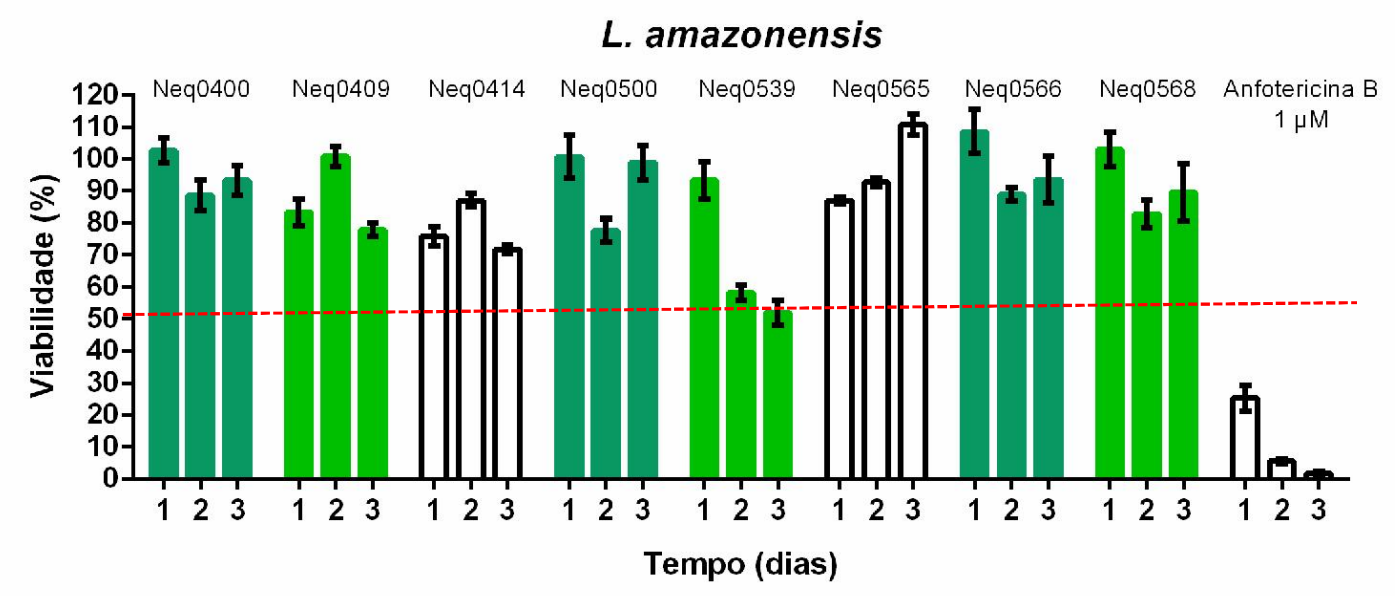

\section{L. chagasi}

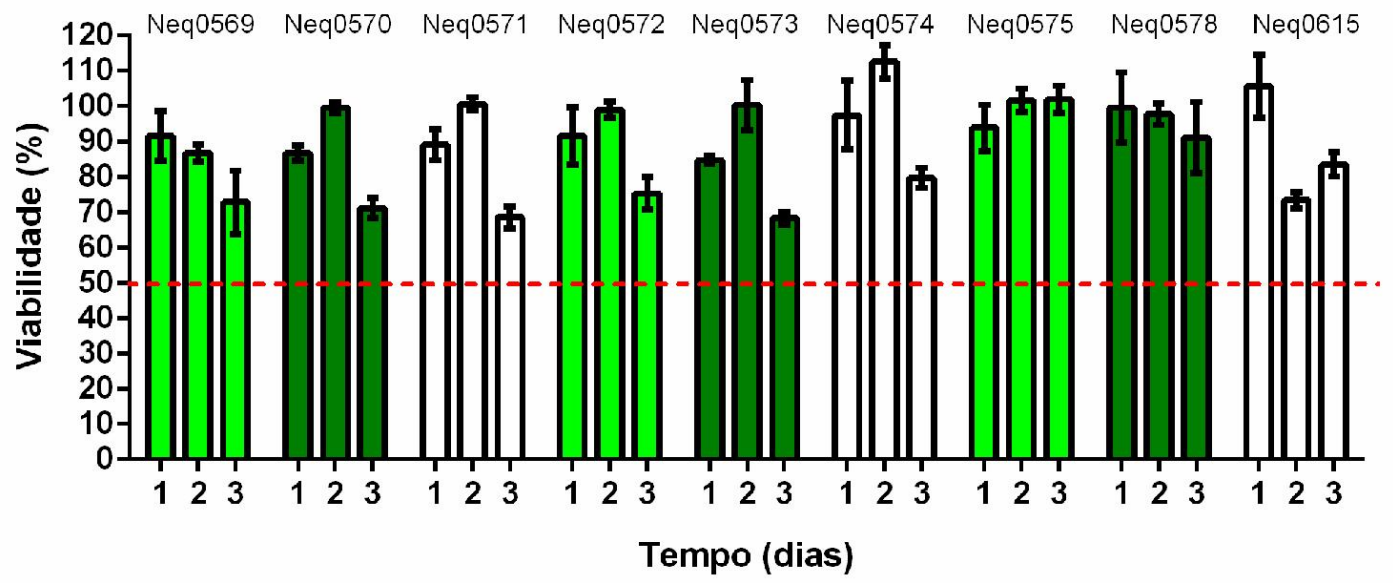

Os ensaios in vitro demonstram que os inibidores de cisteíno proteases apresentaram resultados apenas em alguns casos, mesmo para substâncias com potência na ordem de nanomolar nos ensaios bioquímicos realizados por outros membros do grupo com a cruzaína. A falta de relação entre os ensaios celulares e bioquímicos está sendo atualmente explorada em outros projetos no NEQUIMED. 


\subsection{Inibidores de $\mathrm{DHODH}$}

Neste trabalho apenas uma molécula com este mecanismo de ação foi analisada, a Neq0071. Ensaios com o tripanossoma e com as espécies de leishmania foram realizados, porém sem atividade significativa (Fig. 33). Apesar de ter excelente potência contra a enzima pura e isolada, a substância não teve efeito quando testada diretamente com o parasito. Isso pode estar relacionado com o metabolismo da molécula antes de chegar no alvo, ou mesmo a sua baixa permeabilidade no parasita e consequentemente a não ligação com o alvo macromolecular.

Figura 33. Triagem de compostos inibidores de DHODH nos tripanossomatídeos.
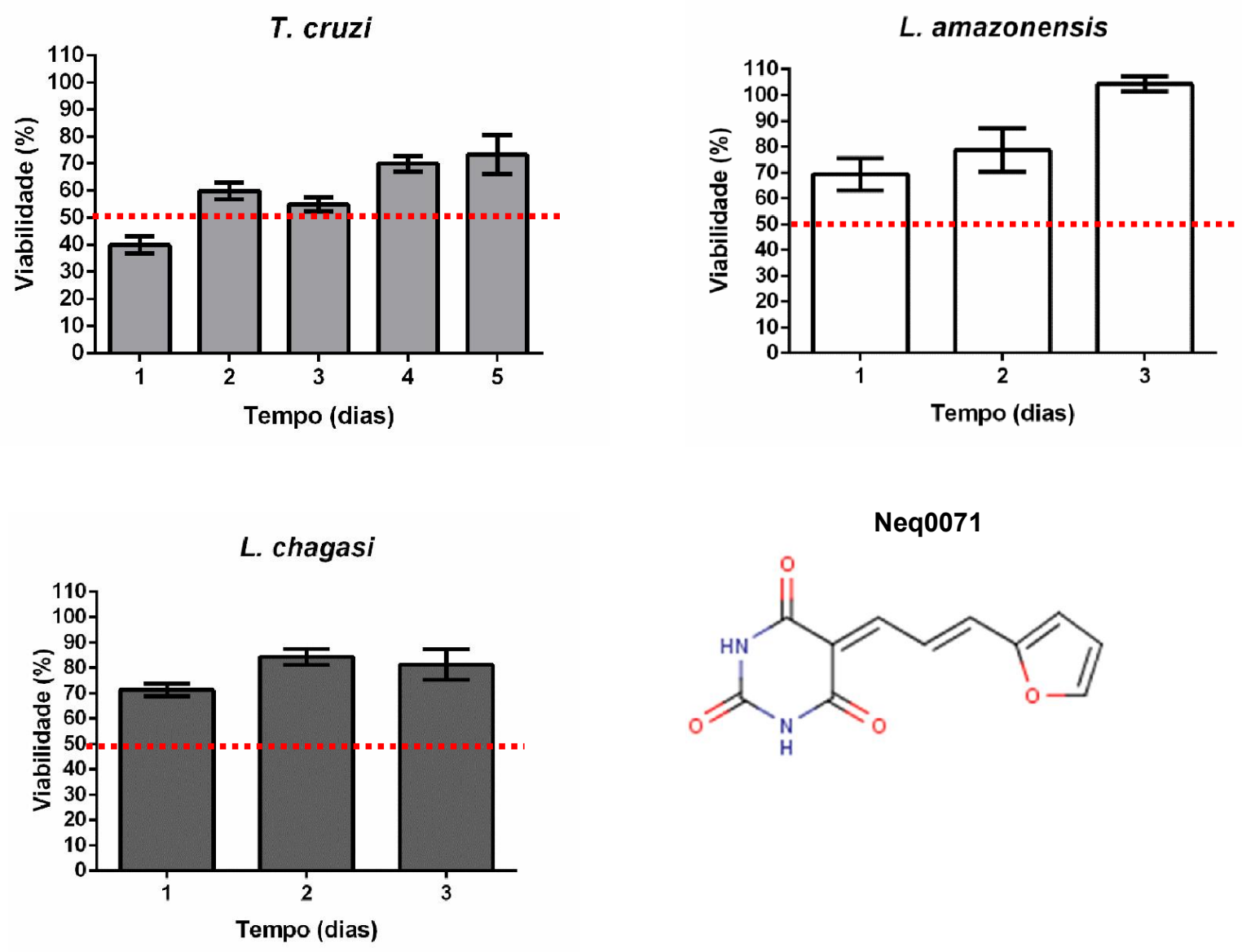


\subsection{Inibidores da GAPDH}

A enzima glicolítica GAPDH (gliceraldeído-3-fosfato desidrogenase) tem várias funções, regulando a apoptose, transporte nuclear de RNA, replicação de DNA, entre outros. Porém o papel mais importante exercido por ela é a produção de energia (ATP), o que é vital para os organismos.

Para o tripanossoma, somente o Neq0405 apresenta atividade inibitória que começa desde o primeiro dia e permanece constante (Fig. 34). No caso da Leishmania spp., nenhum composto apresentou atividade. Todos os ensaios foram realizados com $100 \mu \mathrm{mol} / \mathrm{L}$ do composto, em quintuplicata em dois experimentos distintos.

Figura 34. Triagem de compostos inibidores da GAPDH nos tripanossomatídeos, através do método colorimétrico.

T. cruzi

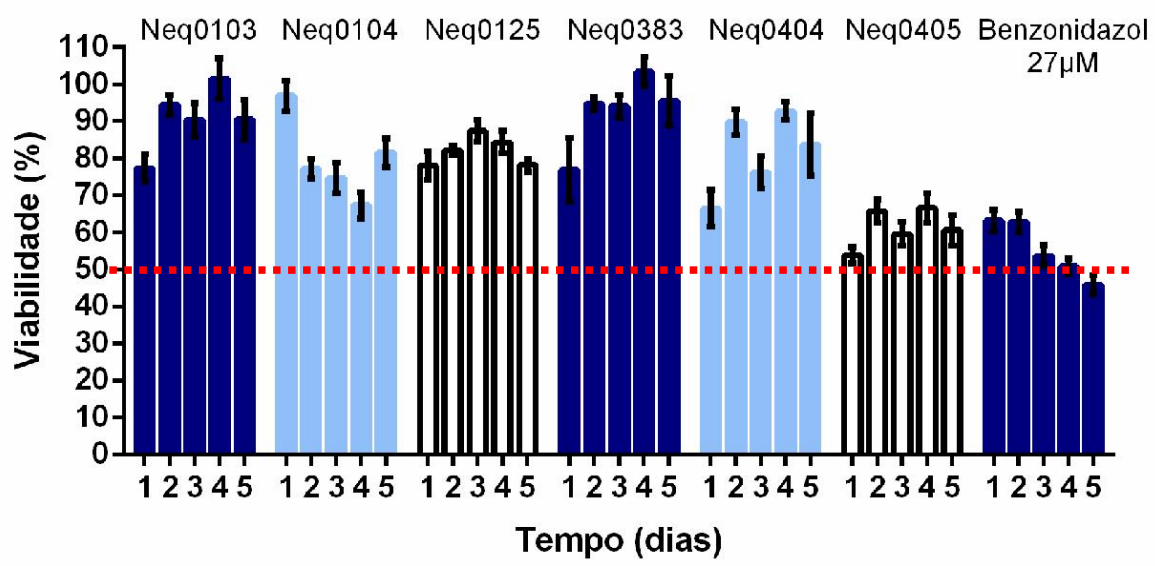

L. amazonensis

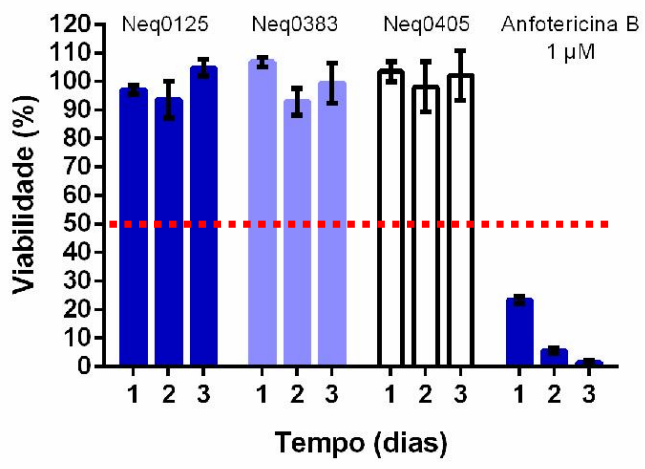

L. chagasi

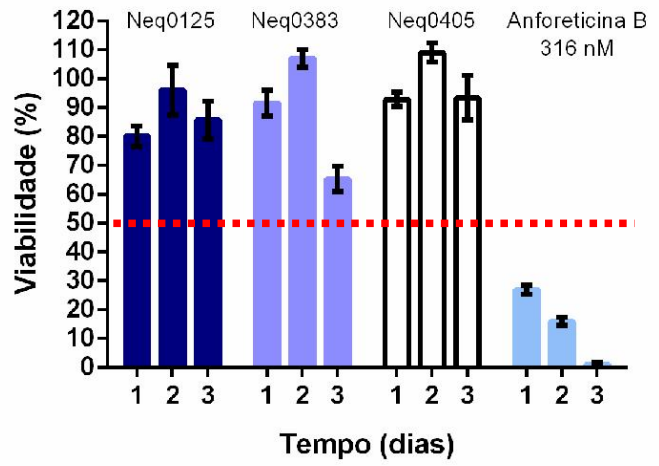




\subsection{Substâncias com potencial inibição de quinases}

A família das proteínas quinases possui muitos membros com uma atividade funcional em comum, que é a capacidade de retirar o fosfato de um grupo altamente energético (ATP) e transferir para os resíduos de serina, treonina ou tirosina, ou seja, catalisar a fosforilação destes aminoácidos. Uma via muito comum que é conhecida para as células de mamífero, é a via da AKT, importante para ativar a produção de proteínas. A rapamicina, que inibe a mTOR, uma quinase no meio dessa via de sinalização, apresenta atividade anticancerígena conhecida em células de humanos. O parasito possui uma TOR similar à de mamíferos, sendo descrito na literatura que a rapamicina inibe esta quinase, com consequente morte do parasito ${ }^{104}$. Resultados obtidos em nosso grupo para células cancerígenas demonstraram que alguns compostos se comportaram semelhante a rapamicina em células de mamíferos, inclusive com inibição da mTOR. Desta forma, decidimos estudar estes inibidores de quinases nos parasitos.

As substâncias usadas neste trabalho foram planejadas computacionalmente baseado nas estruturas e propriedades físico-químicas de inibidores de mTOR, uma serina-treonina quinase. As triagens das substâncias foram realizadas em $100 \mu \mathrm{M}$ em quadruplicata em dois ensaios distintos. Para $T$. cruzi a incubação é mantida por cinco dias e para as duas espécies de leishmania mantidas por três dias.

Dentre as substâncias ensaiadas, Neq0440, Neq0443, Neq444, Neq0451, Neq0452, Neq0453 e Neq0474 apresentaram inibição acima de $50 \%$ da resposta celular (Fig. 35). Algumas destas substâncias acabaram e estão em processo de aquisição novamente da empresa ChemBridge, o que levou a estudos pela contagem na câmara de Neubauer para somente parte da série estudada (Fig. 36) confirmando os resultados alcançados no método colorimétrico.

A substância com a melhor resposta biológica de inibição de parasitas do $T$. cruzi é a Neq0474, cujo ensaio inicial apresenta $55 \%$ de inibição (primeiro dia) e aumenta para $85 \%$, ou seja, após cinco dias de incubação apenas $15 \%$ de parasitas encontram-se viáveis. O mesmo resultado foi alcançado para os dois métodos de triagem (Fig. 35 e 36), sendo necessário realizar o ensaio de concentração-resposta para esta substância. 
Figura 35. Triagem de compostos inibidores de quinases na forma epimastigota da cepa $Y$ do T. cruzi com o método colorimétrico (MTT).

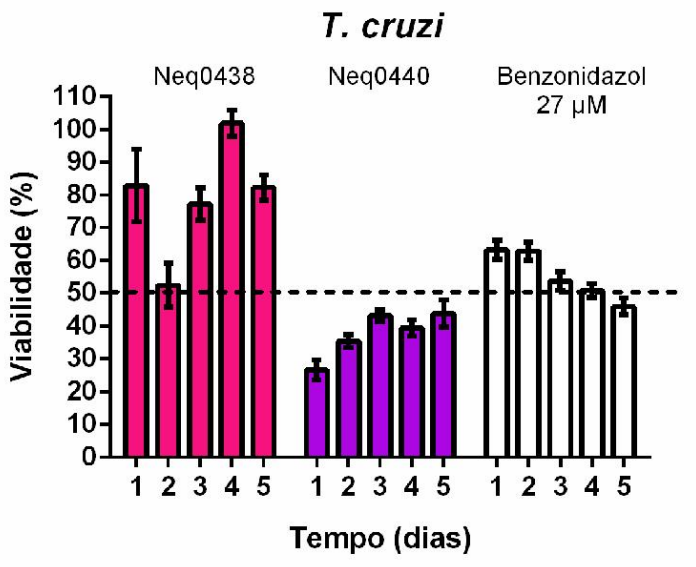

T. cruzi (método colorimétrico)

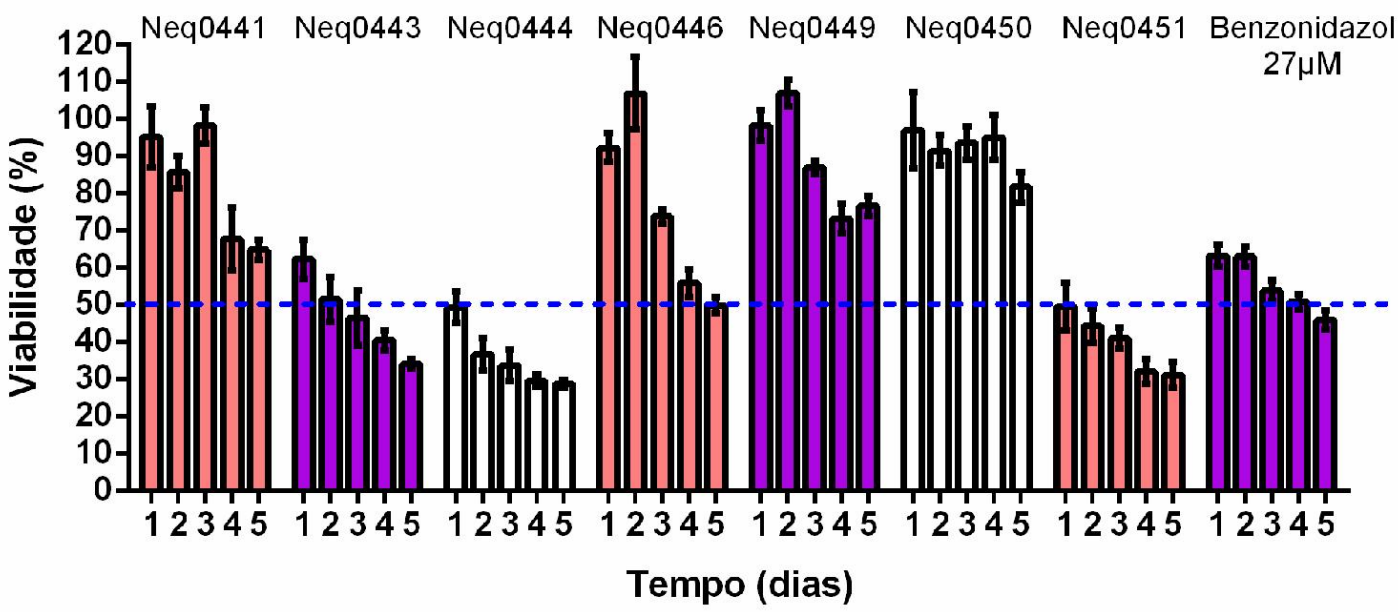

T. cruzi (método colorimétrico)

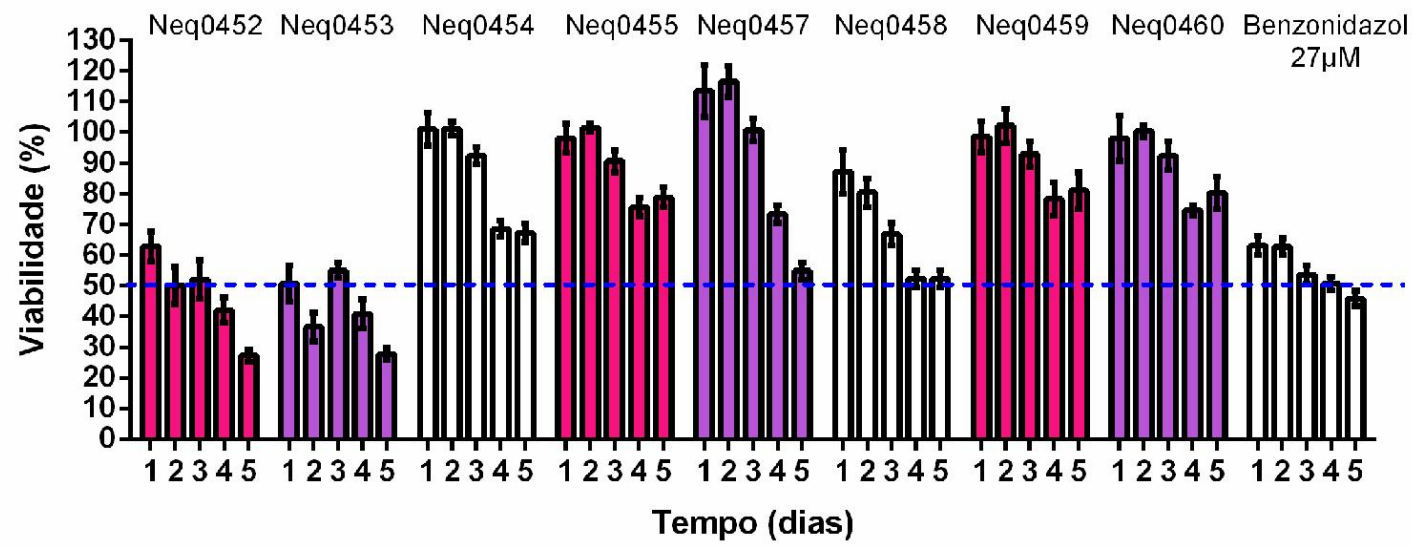


T. cruzi (método colorimétrico)

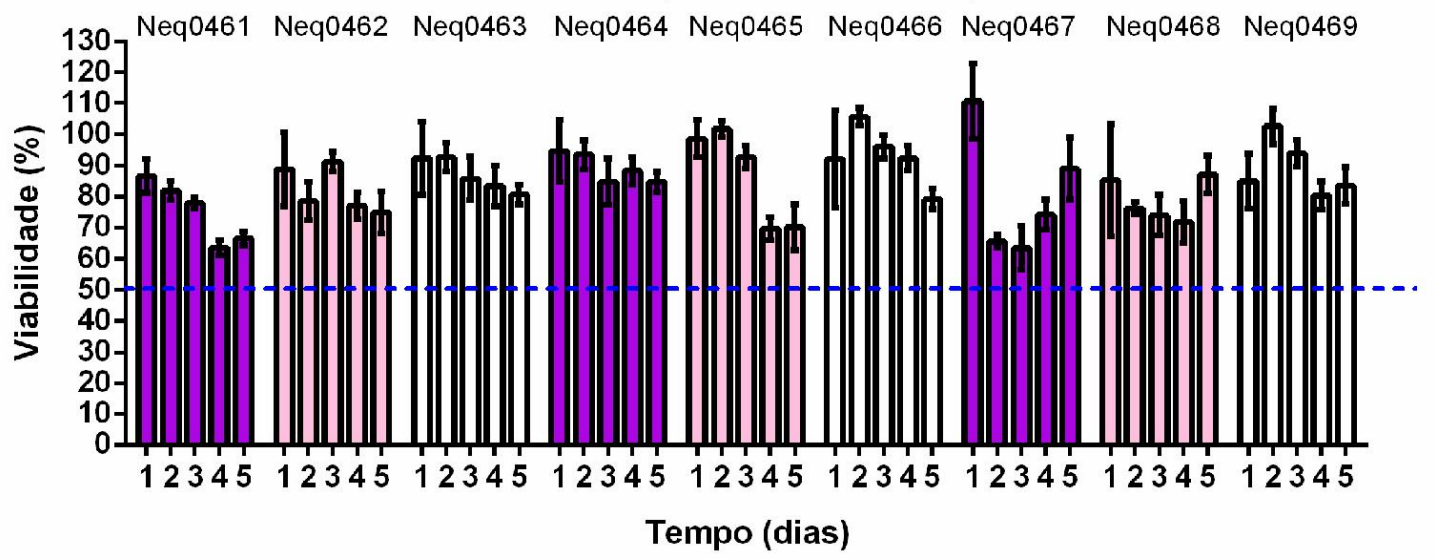

T. cruzi (método colorimétrico)

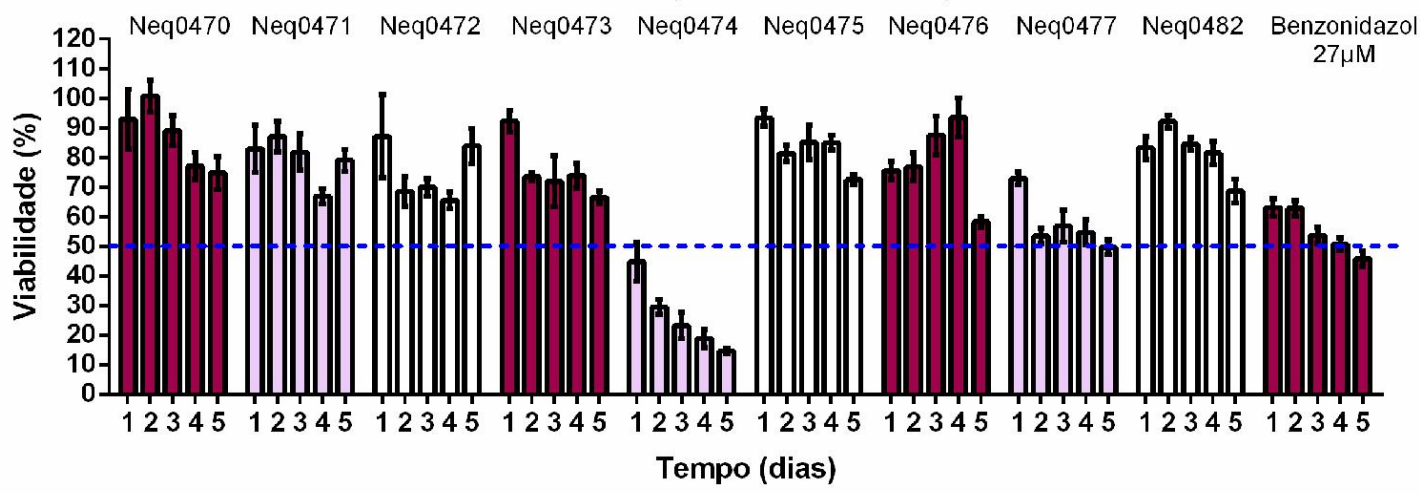

Para o composto de melhor potência (Neq0474), estudos para a obtenção de curva concentração-resposta foram realizados. As concentrações de $1 \mu \mathrm{mol} / \mathrm{L}$ a 250 $\mu \mathrm{mol} / \mathrm{L}$ foram usadas, com morte de $100 \%$ dos parasitos na concentração mais alta (Fig. 37). Os testes foram realizados em triplicata em dois ensaios distintos com 5 dias de incubação e análise a cada dia, sendo apresentado na Fig. 37 somente o resultado do último dia, que apresentou maior potência para a substância. Os valores dos parâmetros estatísticos estão excelentes $\left(r^{2}=0,984\right.$; Sy.x $\left.=4,02\right)$ com $E_{50}=51,7 \pm$ $2,06 \mu \mathrm{M}$. 
Figura 36. Triagem de compostos inibidores de quinases na forma epimastigota da cepa $Y$ do T. cruzi usando a contagem com câmara de Neubauer

T. cruzi (contagem por microscopia)

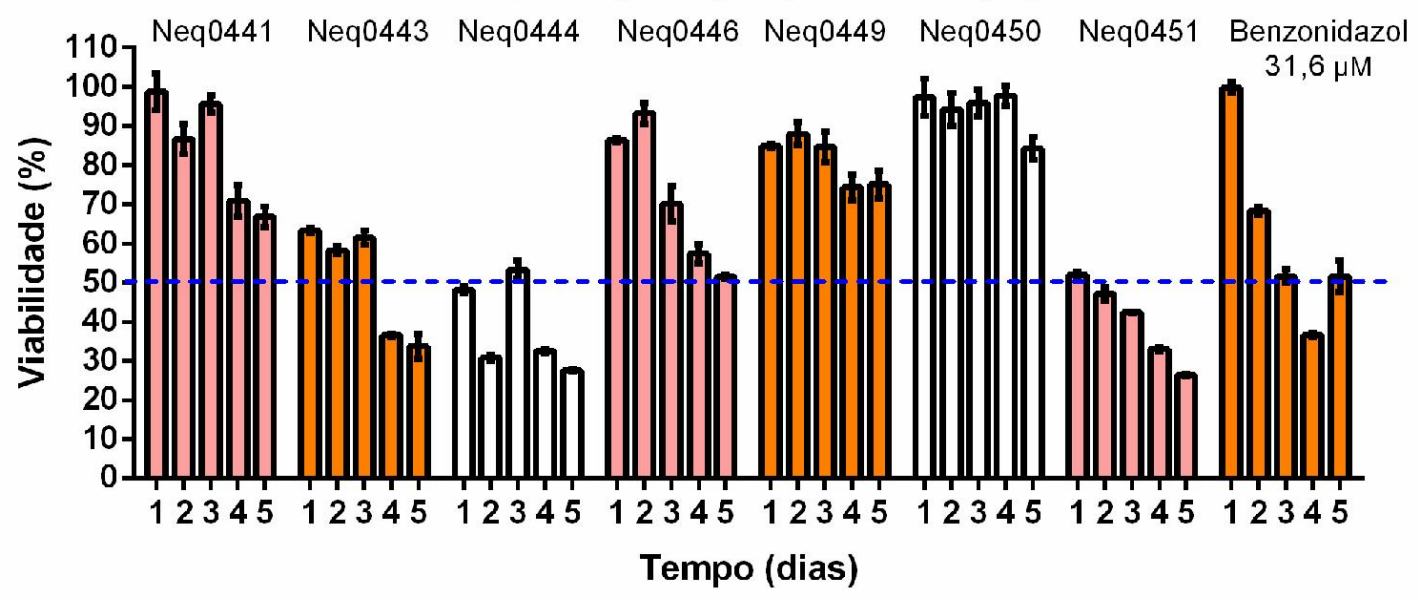

T. cruzi (contagem por microscopia)

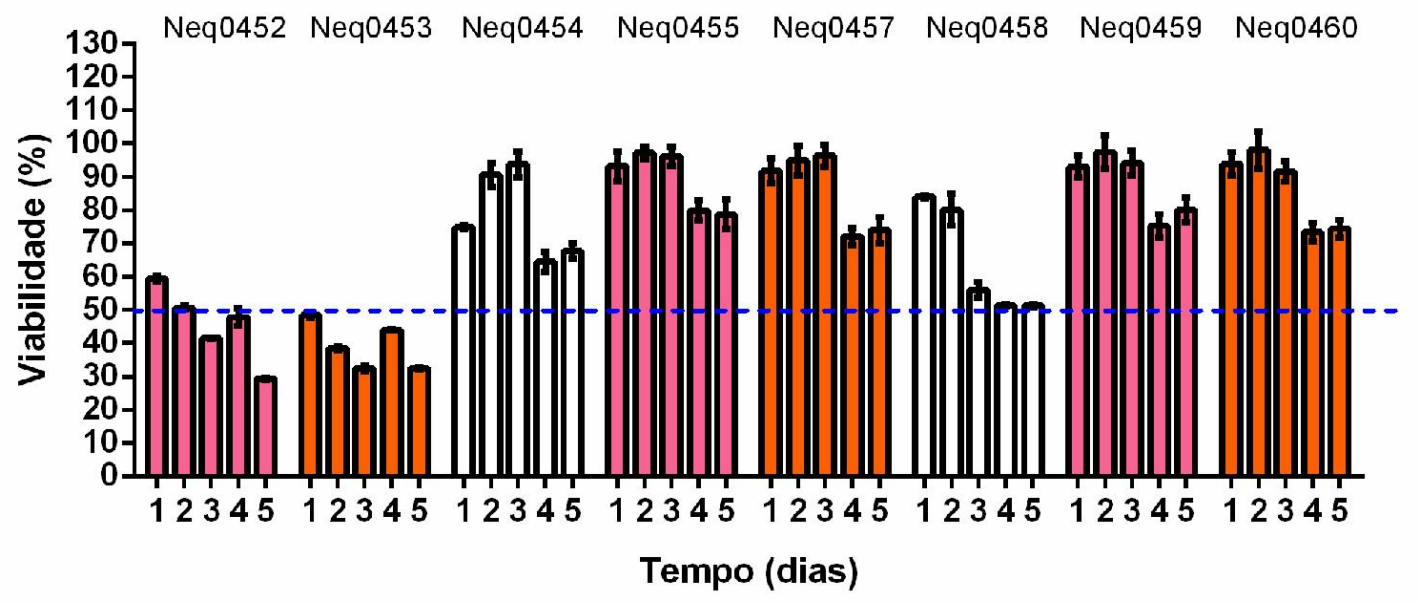

T. cruzi (contagem por microscopia)

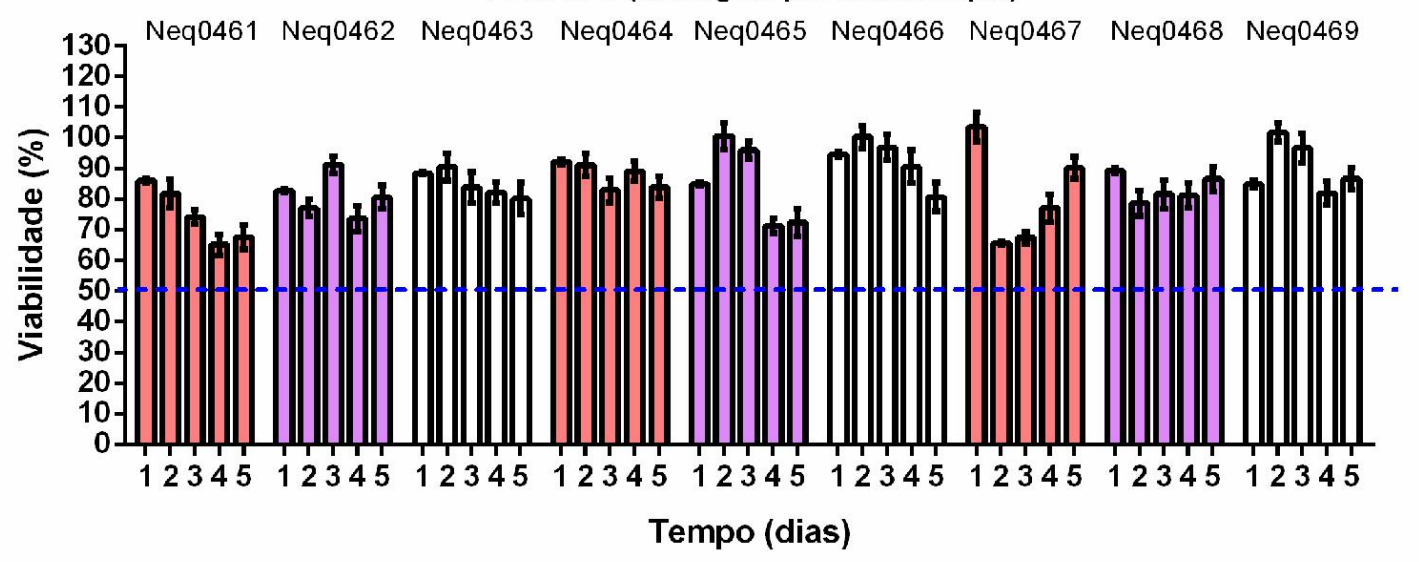


T. cruzi (contagem por microscopia)

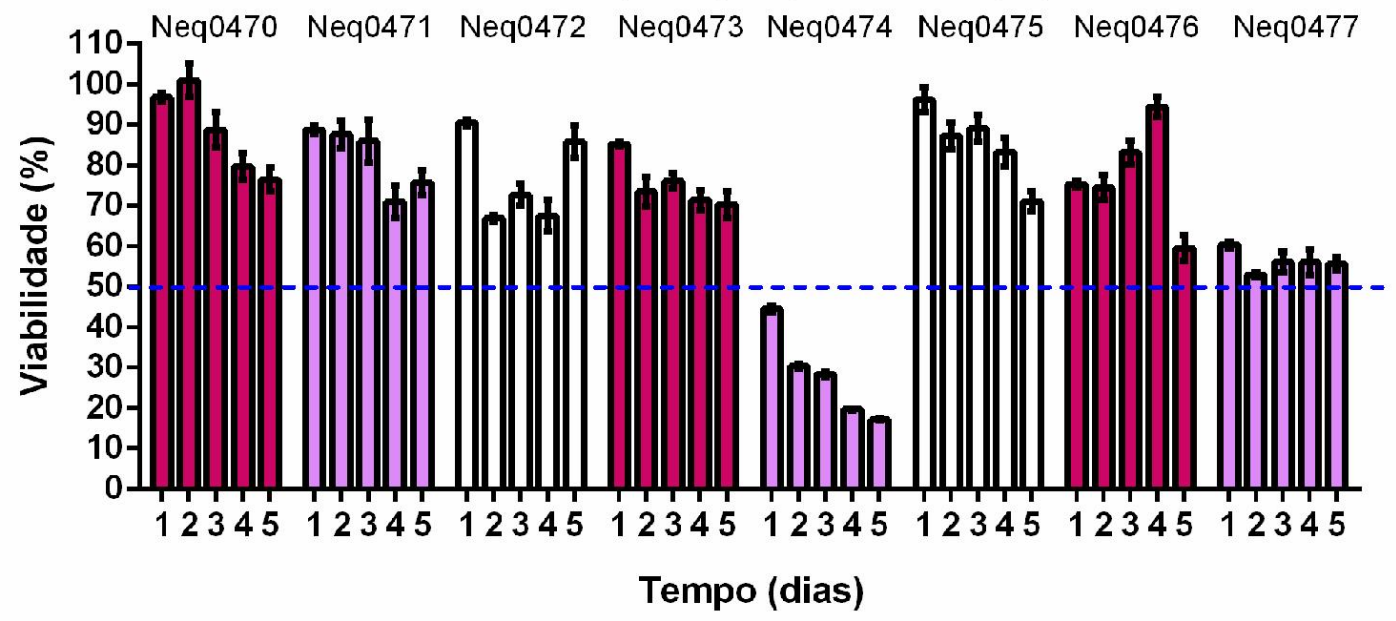

Figura 37. Concentração-resposta com Neq0474 na forma epimastigota da cepa Y do T. cruzi após 5 dias de incubação.

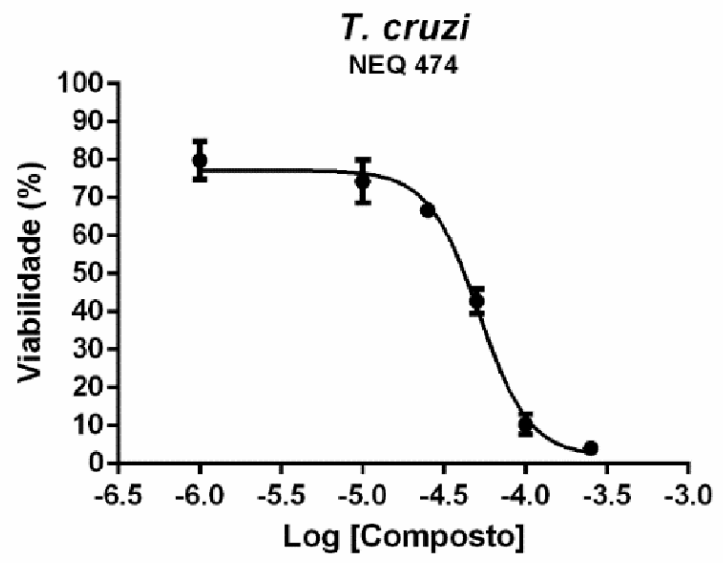

Para Leishmania spp., a contagem por microscopia não foi realizada visto que os resultados do método colorimétrico e de contagem com câmara de Neubauer se equivaliam em todos os testes realizados anteriormente.

As triagens realizadas para L. chagasi (Fig. 38) demonstraram que as substâncias foram inativas, demonstrando que este parasito é mais resistente aos derivados de inibidores de quinases. Por outro lado, a sensibilidade de $L$. amazonensis foi maior, sendo Neq0438 ativo (Fig. 39). É interessante notar que Neq0474 foi inativo para ambas espécies de Leishmania, o que demonstra ser um inibidor seletivo para o T. cruzi. Os ensaios foram realizados em quadruplicata em dois experimento distintos, incubando com os compostos por três dias. 
Figura 38. Triagem de compostos inibidores de quinases em L. chagasi pelo método colorimétrico (MTT).

\section{L. chagasi}

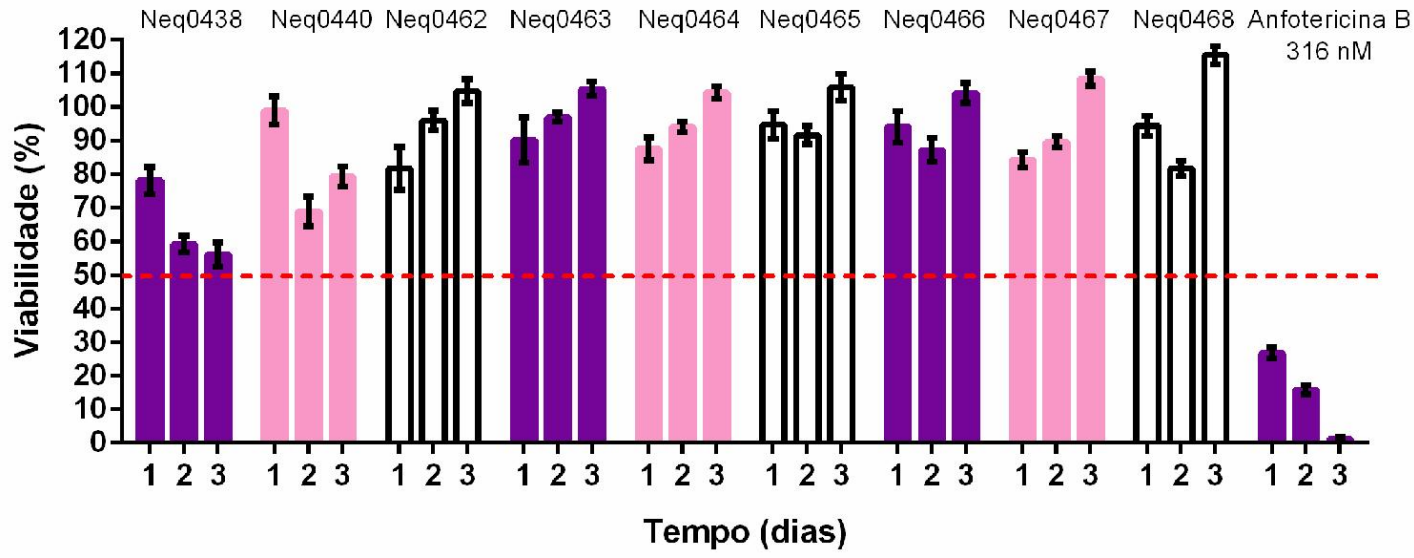

\section{L. chagasi}

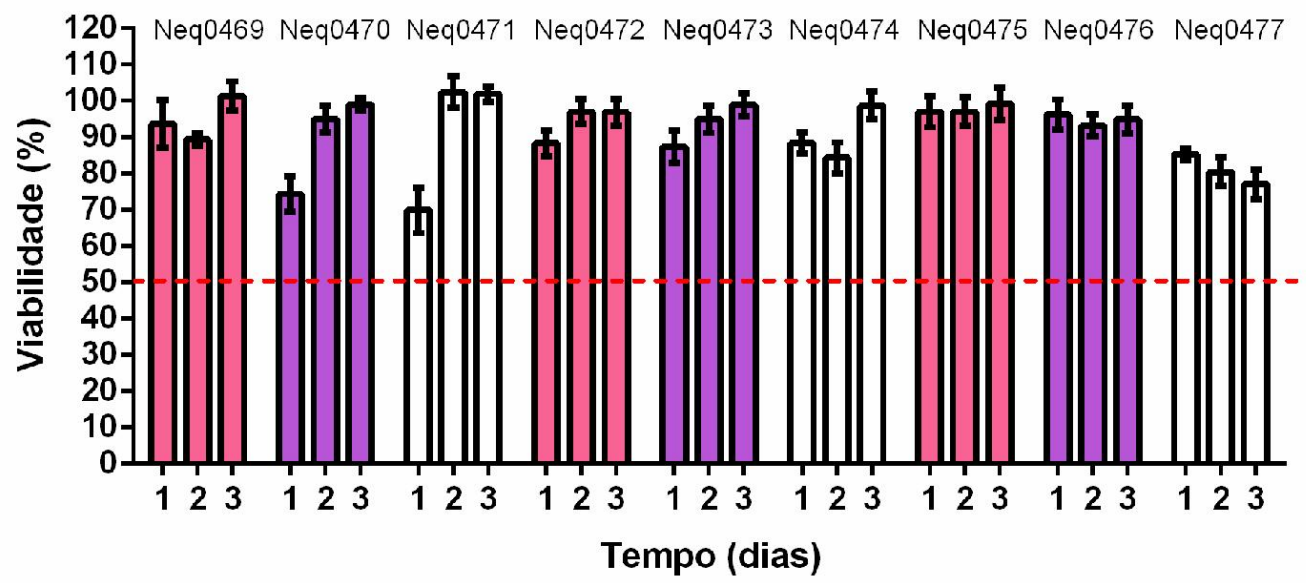


Figura 39. Triagem de compostos inibidores de quinases em L. amazonensis pelo método colorimétrico (MTT).

\section{L. amazonensis}

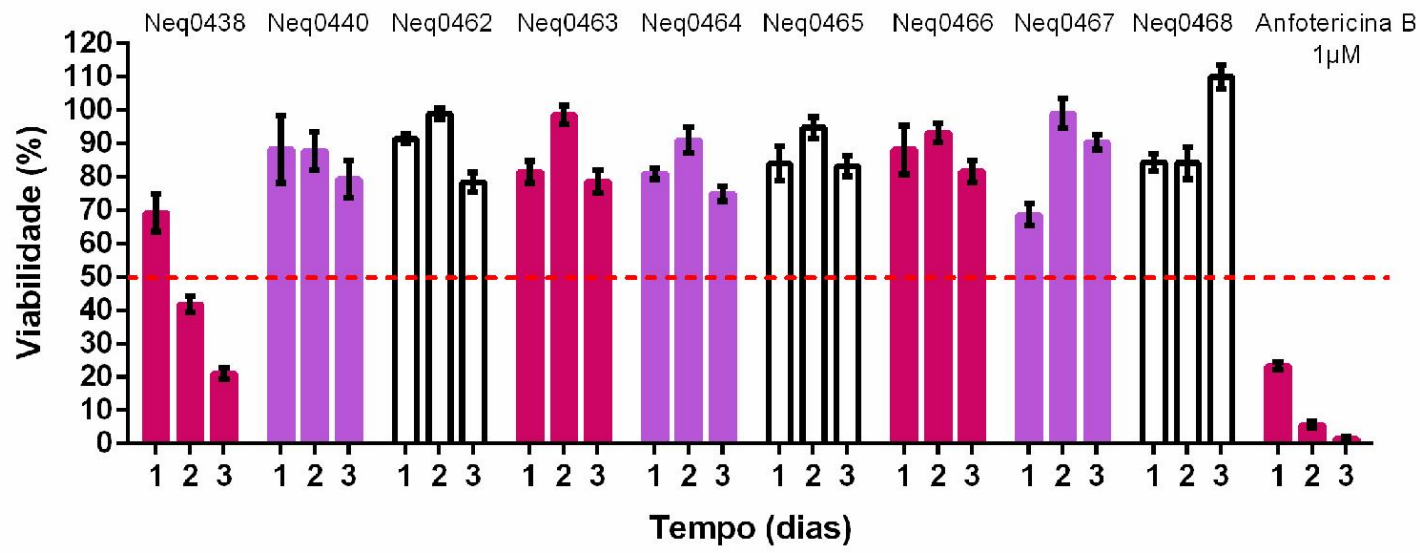

\section{L. amazonensis}

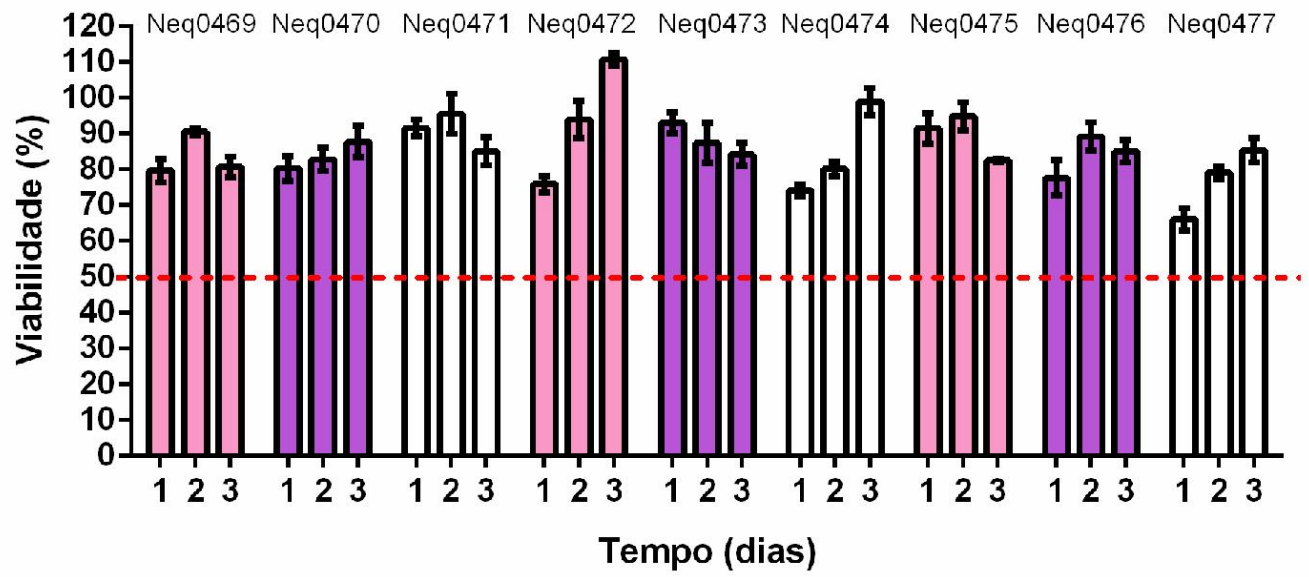

4.6 Determinação da viabilidade celular por citometria de fluxo para os fármacos de referência

Várias técnicas baseadas no uso de sonda fluorescente têm sido desenvolvidas e empregados para determinar parâmetros quantitativos de informação estrutural e funcional do comportamento celular. Neste ensaio de contagem e determinação da viabilidade celular, o reagente Guava ViaCount ${ }^{\circledR}$ foi aplicado para realizar uma validação dos resultados alcançados para as triagens por MTT.

Este reagente diferencia células viáveis e não viáveis baseados na permeabilidade dos fluoróforos que interagem com o DNA, permitindo a avaliação 
quantitativa de células viáveis e não viáveis presentes na amostra. O sistema conta as células nucleadas pelo fluoróforo permeável a membrana; e células mortas quando o fluorórofo impermeável entra na célula devido a abertura de poros na membrana. Além disso, o citômetro de fluxo usa a luz que passa sem desvio na amostra (foward scatter, FSC) para distinguir células intactas e restos celulares.

Como um estudo complementar a este trabalho, uma análise da viabilidade dos tripanossomatídeos através de citometria de fluxo foi realizada, utilizando para cada parasita seu composto de referência (benzonidazol/anfotericina B). Para o $T$. cruzi, o ensaio foi realizado em triplicata, em dois experimentos distintos, sendo incubados por cinco dias, enquanto que para as espécies de leishmania ocorreu incubação por 3 dias. A análise foi realizada apenas no último dia de incubação.

Todos os resultados obtidos desta concentração-resposta (Fig. 40) apresentam boa correlação com os estudos colorimétricos, demonstrando uma correspondência entre eles e a confirmação da atividade das substâncias de referência.

A partir destes ensaios, será possível realizar os estudos com as novas moléculas bioativas usando ambos os métodos (colorimétrico por MTT e citometria de fluxo) para realizar a triagem inicial e confirmação da atividade e potência das substâncias de interesse.

Figura 40. Curvas concentração-resposta dos fármacos de referência benzonidazol (T. cruzi) e anfotericina $B$ ( $L$. chagasi e L. amazonensis) determinada pelo método de citometria de fluxo.

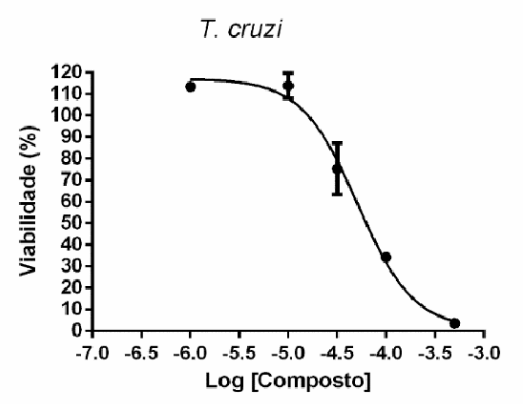

$\mathrm{EC}_{50} \quad 51,1( \pm 8,63) \mu \mathrm{M}$
$r^{2}$

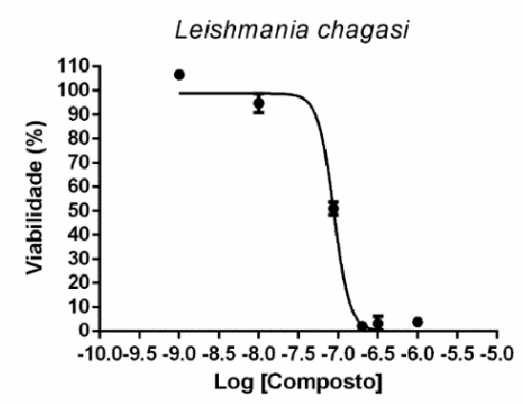

$88,3( \pm 2,82) \mathrm{nM}$ 0,992 4,35

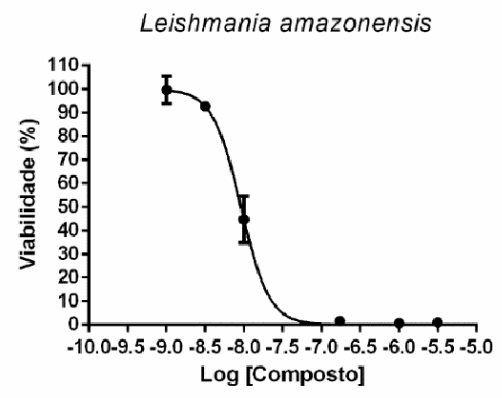

$9,15( \pm 0,368) \mathrm{nM}$ 0,994 3,33 


\subsection{Análise das alterações do ciclo celular para os fármacos de referência}

Dentre as aplicações mais comuns de citometria de fluxo em biologia celular, a análise do conteúdo de DNA individual das células tem mostrado informações importantes relacionados com o ciclo celular e a proliferação celular. Este ensaio utiliza um fluoróforo que interage com o DNA e, assim, é determinada em que fase do ciclo celular a célula se encontra. Por conseguinte, a célula apresenta maior fluorescência devido ao maior conteúdo de material genético. Quando as células estão na fase $G_{1}$ do ciclo elas apresentam conteúdo de material genético $2 \mathrm{~N}$. Na fase intermediária de síntese do DNA (S) o conteúdo de material genético é aumentado. Finalmente, quando as células estão na fase final da replicação celular $\left(G_{2} / M\right)$ essa quantidade cromossômica é dobrada $(4 \mathrm{~N})$. Desta forma, o equipamento consegue detectar as fases do ciclo.

Um ensaio com o $T$. cruzi foi realizado utilizando o benzonidazol a $250 \mu \mathrm{mol} / \mathrm{L}$, incubado com os parasitas por 48 horas. Para confirmar a resposta biológica, a análise foi realizada em triplicata em dois experimentos distintos $(n=6)$.

$O$ benzonidazol apresentou uma pequena retenção na fase $\mathrm{G}_{1}$ em relação ao parasito sem tratamento. Esta alteração pode ser considerada pouco significativa, quando comparada com a elevada concentração usada no ensaio. Este composto leva à morte do parasita, porém não causa grande alteração no ciclo do mesmo, ou seja, é ciclo inespecífico, conforme observado em estudos prévios. ${ }^{12}$

O fármaco de referência utilizado para Leishmania spp. ${ }^{105}$ foi a anfotericina $B$, com estudos por triplicata em dois ensaios distintos $(n=6)$. Nestas condições, as análises foram realizadas após 6 e 12 horas de incubação.

Há uma relação entre a concentração e a resposta, onde a maior concentração da substância leva a uma maior retenção do ciclo na fase pré-G1 (Fig. 42 e 43). Além disso, o maior tempo de incubação também leva a maior resposta, com o mesmo perfil de alteração no ciclo.

Os dados obtidos para a $L$. amazonensis também demonstram o mesmo perfil de resposta observado para $L$. chagasi, onde há uma relação da concentração e tempo de incubação com a retenção sub- $\mathrm{G}_{1}$ da replicação celular (Fig. 44 e 45). Como observado anteriormente para os estudos de concentração-resposta para a anfotericina $B$ nas duas espécies de leishmania (e também nos ensaios de triagem 
com as novas moléculas bioativas) a L. amazonensis apresentou maior sensibilidade a anfotericina $\mathrm{B}$ em relação a $L$. chagasi.

Figura 41. Ciclo celular do T. cruzi sem tratamento (A) e com incubação por 48 h de $250 \mu \mathrm{M}$ de benzonidazol (B).

A

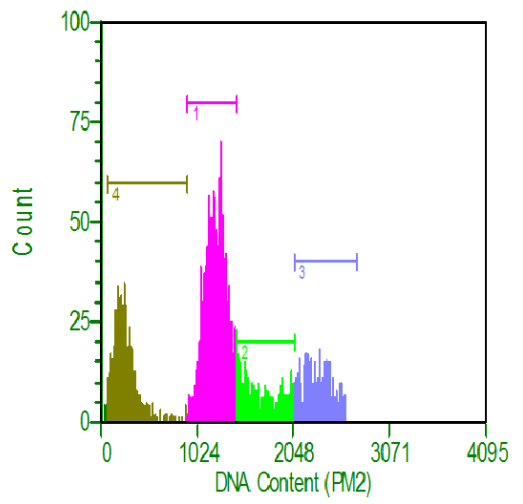

B

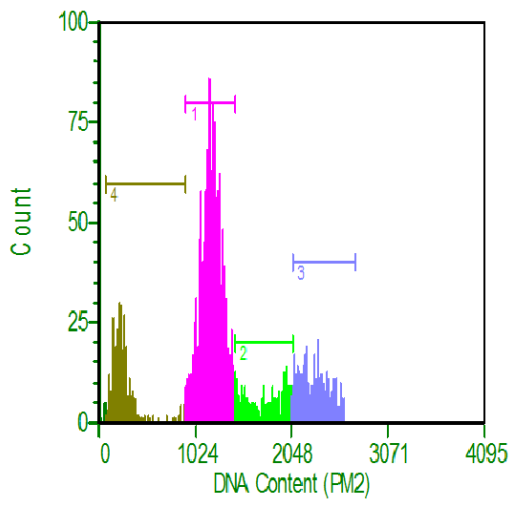

\section{T. cruzi (\%) \\ $\mathbf{G}_{0}(4)$ \\ $\mathbf{G}_{1}(1)$}

S (2)

$\mathbf{G}_{2} / \mathbf{M}(3)$

\begin{tabular}{ccccc}
\hline Sem tratamento & $21,4 \pm 6,53$ & $46,6 \pm 2,46$ & $14,3 \pm 5,3$ & $16,9 \pm 4,6$ \\
$250 \mu \mathrm{M}$ & $15,2 \pm 2,54$ & $57 \pm 2,75$ & $10,8 \pm 3,89$ & $16,6 \pm 3,1$ \\
\hline
\end{tabular}

Figura 42. Ciclo celular da L. chagasi sem tratamento (A) e com incubação por 6 h de $500 \mu \mathrm{M}(\mathrm{B})$ e $200 \mu \mathrm{M}(\mathrm{C})$ de anfotericina B.

A

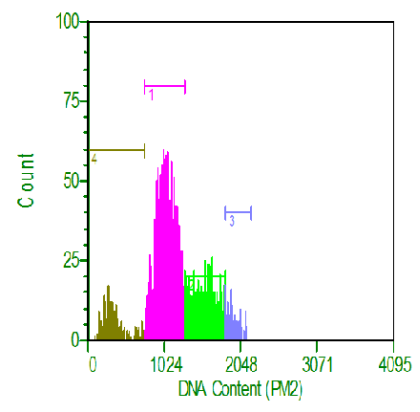

B

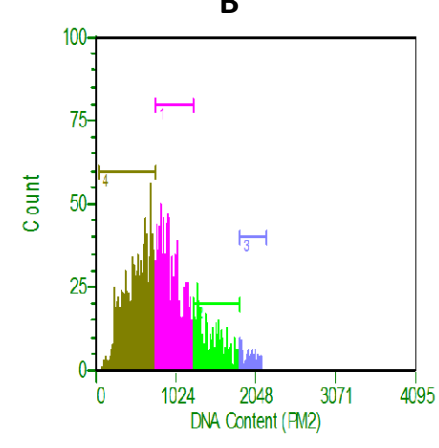

C

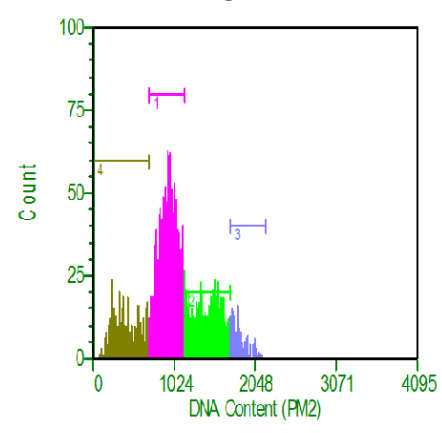

\begin{tabular}{ccccc}
\hline L. chagasi (\%) & $\mathbf{G}_{\mathbf{0}}(\mathbf{4})$ & $\mathbf{G}_{\mathbf{1}}(\mathbf{1})$ & $\mathbf{S}(\mathbf{2})$ & $\mathbf{G}_{\mathbf{2}} / \mathbf{M}(\mathbf{3})$ \\
\hline Sem tratamento & $10,4 \pm 1,3$ & $57,3 \pm 4,5$ & $25,7 \pm 6,5$ & $6,7 \pm 1,3$ \\
$200 \mathrm{nM}$ & $18,3 \pm 2,1$ & $48,9 \pm 5,2$ & $25,7 \pm 2,8$ & $7,1 \pm 1,1$ \\
$500 \mathrm{nM}$ & $39,5 \pm 1,2$ & $39,9 \pm 4,7$ & $17 \pm 3,6$ & $3,6 \pm 0,3$ \\
\hline
\end{tabular}


Figura 43. Ciclo celular da L. chagasi sem tratamento (A) e com incubação por 12 h de $500 \mu \mathrm{M}$ (B) e $200 \mu \mathrm{M}$ (C) de anfotericina $B$.

A

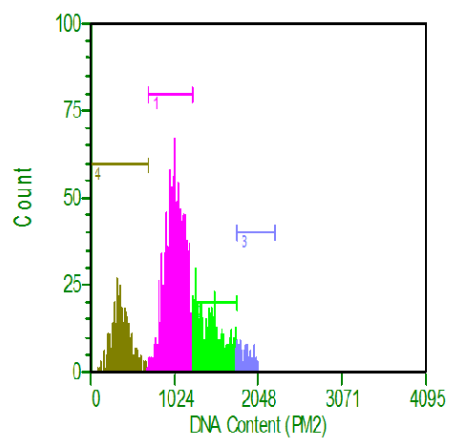

B

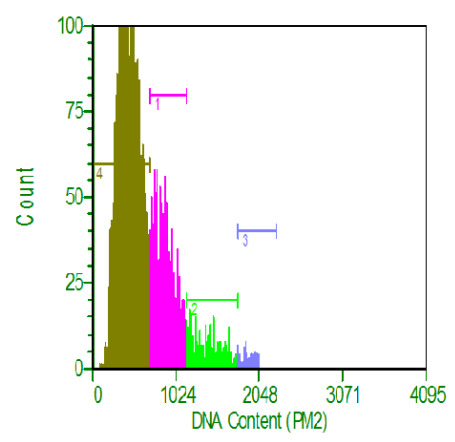

C

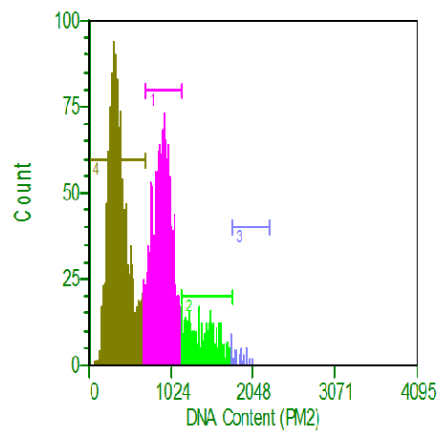

L. chagasi (\%) $\quad \mathrm{G}_{0}(4)$

$\mathbf{G}_{1}(\mathbf{1})$

S (2)

$\mathrm{G}_{2} / \mathrm{M}$ (3)

\begin{tabular}{ccccc}
\hline Sem tratamento & $17,3 \pm 1,5$ & $54,3 \pm 4,8$ & $23,4 \pm 3,2$ & $4,9 \pm 0,51$ \\
$200 \mathrm{nM}$ & $47,2 \pm 5,6$ & $39,7 \pm 4,2$ & $11,9 \pm 1,2$ & $1,2 \pm 0,13$ \\
$500 \mathrm{nM}$ & $64,9 \pm 7,2$ & $25,5 \pm 1,9$ & $8 \pm 0,9$ & $1,6 \pm 0,22$ \\
\hline
\end{tabular}

Figura 44. Ciclo celular da L. amazonensis sem tratamento (A) e com incubação por 6 h de $500 \mu \mathrm{M}(\mathrm{B})$ e $200 \mu \mathrm{M}$ (C) de anfotericina B.

A

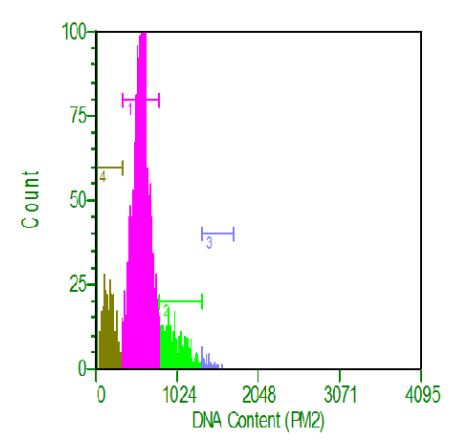

B

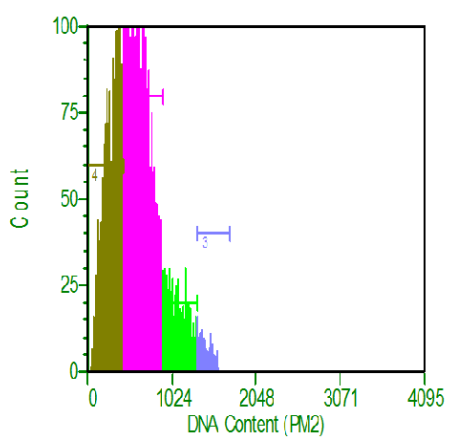

C

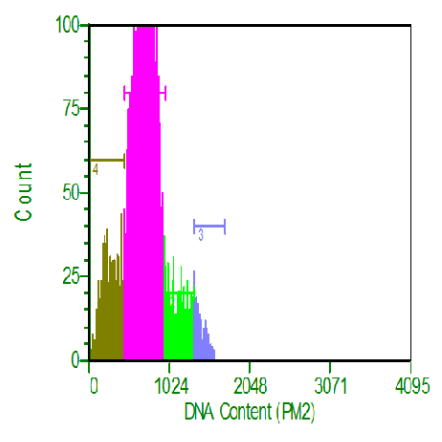

\begin{tabular}{ccccc}
\hline L. amazonensis (\%) & $\mathbf{G}_{\mathbf{0}}(\mathbf{4})$ & $\mathbf{G}_{\mathbf{1}} \mathbf{( 1 )}$ & $\mathbf{S}(\mathbf{2})$ & $\mathbf{G}_{\mathbf{2}} / \mathbf{M}(\mathbf{3})$ \\
\hline Sem tratamento & $13,6 \pm 1,4$ & $72,1 \pm 7$ & $12,7 \pm 1,5$ & $1,6 \pm 0,20$ \\
$200 \mathrm{nM}$ & $13,1 \pm 1,2$ & $73,6 \pm 3,6$ & $9,7 \pm 0,84$ & $3,5 \pm 0,23$ \\
$500 \mathrm{nM}$ & $32 \pm 4,1$ & $53,2 \pm 6$ & $11,1 \pm 0,8$ & $2,7 \pm 0,38$ \\
\hline
\end{tabular}


Figura 45. Ciclo celular da L. amazonensis sem tratamento (A) e com incubação por 12 h de $500 \mu \mathrm{M}(\mathrm{B})$ e 200 $\mu \mathrm{M}(\mathrm{C})$ de anfotericina $\mathrm{B}$.

A

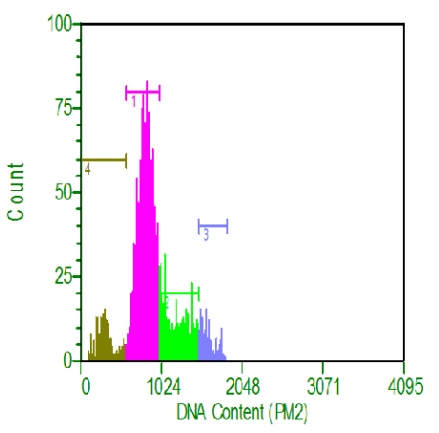

B

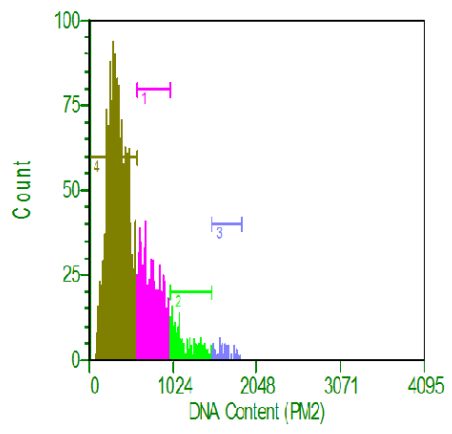

C

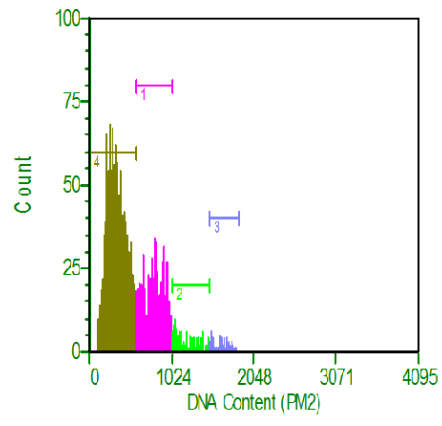

S (2)

$\mathbf{G}_{2} / \mathbf{M}(3)$

\section{L. amazonensis (\%)}

$$
G_{0}(4)
$$

$\mathbf{G}_{1}$ (1)

$21,7 \pm 1,8$

$7,4 \pm 0,94$

\begin{tabular}{ccccc}
\hline Sem tratamento & $9,7 \pm 0,65$ & $61,2 \pm 5,3$ & $21,7 \pm 1,8$ & $7,4 \pm 0,94$ \\
$200 n M$ & $59,7 \pm 2,4$ & $31,1 \pm 2,1$ & $6,6 \pm 0,55$ & $2,6 \pm 0,23$ \\
$500 n M$ & $64,7 \pm 3,4$ & $26 \pm 1,4$ & $7 \pm 0,43$ & $2,4 \pm 0,21$ \\
\hline
\end{tabular}




\section{Conclusão}

A otimização do protocolo de cultura do parasita foi estabelecida com a colaboração do Prof. Sérgio Albuquerque (FCFRP-USP) que cedeu ambos os parasitas, com padronização adequada do método colorimétrico por MTT e da citometria de fluxo usando ViaCount ${ }^{\circledR}$ com os fármacos de referência para determinação da viabilidade celular. Os dois ensaios em conjunto levam a identificação e confirmação da resposta celular de forma ortogonal.

Outro estudo que também de grande valia para as próximas etapas deste trabalho é a determinação do ciclo celular por meio da citometria de fluxo. Neste caso, tanto benzonidazol quanto anfotericina B levaram a uma inibição ciclo-inespecífica da replicação celular, evitando que as células iniciem o ciclo e consequente acumulação na fase sub- $\mathrm{G}_{1}$ (ou $\mathrm{G}_{0}$ ).

Substâncias com potencial inibição de quinases (ex. Neq0474, Neq0440 e Neq0438) e para cisteíno proteases (Neq0565) foram as mais promissoras, sendo mais eficazes do que as outras classes de substâncias ensaiadas.

L. chagasi apresentou a maior resistência a todas as classes de inibidores, onde nenhuma substância testada foi eficaz. Já $T$. cruzi apresentou a maior sensibilidade, sendo Neq0474 uma das melhores substâncias da série, inclusive com um inibidor de cruzaína/cisteíno protease (Neq0565) sendo ativo. 


\section{Perspectivas}

Com base nos dados obtidos deste estudo, tem-se como perspectiva deste trabalho:

- Realizar os ensaios de concentração-resposta usando o método colorimétrico e citometria de fluxo para determinar a viabilidade celular para as moléculas que apresentaram maior potencial nas triagens iniciais;

- Realizar o ensaio de ciclo celular para as novas substâncias e analisar comparativamente com os fármacos de referência;

- Fazer a infecção de células sadias para a produção da forma amastigota, a qual está representada no organismo humano. Realizar a triagem de compostos na forma amastigota para observar se as substâncias de interesse também apresentarão atividade nesta forma dos parasitos. 


\section{Referências Bibliográficas}

1. HENRY, D.; LEXCHIN, J. The pharmaceutical industry as a medicines provider. Lancet, v.360, p.1590-1595, 2002.

2. TROUILLER, P. et al. Drug development for neglected diseases: A deficient market and a publichealth policy failure. Lancet, v.359, p.2188-2194, 2002.

3. CAMARGO, E. P. Doenças tropicais. Estud. Avançados, v.22, p.95-110, 2008.

4. WIDDUS, R. Public-private partnerships for health: Their main targets, their diversity, and their future directions. Bull. World Health Organ., v.79, p.713-720, 2001.

5. DA SILVA, C. F. et al. In vitro trypanocidal activity of DB745B and other novel arylimidamides against Trypanosoma cruzi. J. Antimicrob. Chemother., v.66, p.1295-1297, 2011.

6. MUELAS-SERRANO S.; NOGAL-RUIZ J.J., G.-B. A. Setting of a colorimetric method to determine the viability of Trypanosoma cruzi epimastigotes. Parasitol. Res., v.86, p.999-1002, 2000.

7. CUNHA, W. R. et al. A study of the trypanocidal activity of triterpene acids isolated from Miconia species. Phyther. Res., v.20, p.474-478, 2006.

8. CAMPOS, M. C. O.; LEON, L. L.; TAYLOR, M. C.; KELLY, J. M. Benznidazole-resistance in Trypanosoma cruzi: Evidence that distinct mechanisms can act in concert. Mol. Biochem. Parasitol., v.193, p.17-19, 2014.

9. RASSI, A.; MARIN-NETO, J. A. Chagas disease. Lancet, v.375, p.1388-1402 2010.

10. RASSI, A.; DIAS, J. C. P.; MARIN-NETO, J. A.; RASSI, A. Challenges and opportunities for primary, secondary, and tertiary prevention of Chagas' disease. Heart , v.95, p.524-534 2009.

11. VEIGA-SANTOS, P. et al. Effects of amiodarone and posaconazole on the growth and ultrastructure of Trypanosoma cruzi. Int. J. Antimicrob. Agents, v.40, p.61-71, 2012.

12. ZUMA, A. A. et al. How Trypanosoma cruzi handles cell cycle arrest promoted by camptothecin, a topoisomerase i inhibitor. Mol. Biochem. Parasitol., v.193, p.93-100, 2014.

13. ARAÚJO, C. A.C.; CABELLO, P. H.; JANSEN, A. M. Growth behaviour of two Trypanosoma cruzi strains in single and mixed infections: In vitro and in the intestinal tract of the blood-sucking bug, Triatoma brasiliensis. Acta Trop., v.101, p.225-231, 2007.

14. MUELAS, S. et al. In vitro and in vivo assays of 3,5-disubstituted-tetrahydro-2H-1,3,5-thiadiazin2-thione derivatives against Trypanosoma cruzi. Mem. Inst. Oswaldo Cruz, v.97, p.269-272, 2002.

15. COURA, J.R.; VINÃS, P. Chagas disease: a new worldwide challenge. Nature, v.465, p.S6-S7, 2010. 
16. COURA, J. R.; DE CASTRO, S. L. A critical review on chagas disease chemotherapy. Mem. Inst. Oswaldo Cruz, v.97, p.3-24, 2002.

17. BRENER, Z. Biology of Trypanosoma cruzi. Microbiology, v.27, p.347-382, 1973.

18. TYLER, K. M.; ENGMAN, D. M. The life cycle of Trypanosoma cruzi revisited. Int. J. Parasitol., v.31, p.472-481, 2001.

19. BURLEIGH, B. A; ANDREWS, N. W. Signaling and host cell invasion by Trypanosoma cruzi. Curr. Opin. Microbiol., v.1, p.461-465, 1998.

20. YOSHIDA, N. Molecular basis of mammalian cell invasion by Trypanosoma cruzi. An. Acad. Bras. Cienc., v.78, p.87-111, 2006.

21. TELLERIA, J. et al. Trypanosoma cruzi: Sequence analysis of the variable region of kinetoplast minicircles. Exp. Parasitol., v.114, p.279-288, 2006.

22. CLAYTON, J. Chagas disease 101. Nature S4-S5, 2010. doi:10.1038/nature09220

23. MANNING-CELA, R.; JAISHANKAR, S.; SWINDLE, J. Life-Cycle and Growth-Phase-Dependent Regulation of the Ubiquitin Genes of Trypanosoma cruzi. Arch. Med. Res., v.37, p.593-601, 2006.

24. URBINA, J. A.; DOCAMPO, R. Specific chemotherapy of Chagas disease: Controversies and advances. Trends Parasitol., v.19, p.495-501, 2003.

25. HERNÁNDEZ, R.; CEVALLOS, A. M.; NEPOMUCENO-MEJÍA, T. ; LÓPEZ-VILLASEÑOR, I. Stationary phase in Trypanosoma cruzi epimastigotes as a preadaptive stage for metacyclogenesis. Parasitol. Res. 111, 509-514 (2012).

26. VILLARREAL, D.; BARNABÉ, C.; SERENO, D.; TIBAYRENC, M. Lack of correlation between in vitro susceptibility to Benznidazole and phylogenetic diversity of Trypanosoma cruzi, the agent of Chagas disease. Exp. Parasitol., v.108, p.24-31, 2004.

27. MORENO, N.; DOCAMPO, R.; LEON, W.; MASON, R. P.; STOPPANI, A. M. Different Behaviors of Benznidazole as Free Radical Generator with Mammalian and Trypanosoma cruzi Microsomal Preparations. Arch. Biochem. Biophys., v.218, p.585-591, 1982.

28. DOCAMPO, R.; MORENO, S. N. J. Free Radical Metabolites in the Mode of Action of Chemotherapeutic Agents and Phagocytic Cells on Trypanosoma cruzi. Rev. Infect. Dis., v.6, p.223-238, 1984.

29. DE CASTRO, S. L. The challenge of Chagas' disease chemotherapy: An update of drugs assayed against Trypanosoma cruzi. Acta Trop., v.53, p.83-98, 1993.

30. HOTEZ, P. J.; FERRIS, M. T. The antipoverty vaccines. Vaccine, v.24, p.5787-5799, 2006.

31. TEMPONE, A. G. et al. Antiprotozoal activity of Brazilian plant extracts from isoquinoline alkaloid-producing families. Phytomedicine, v.12, p.382-390, 2005. 
32. MESQUITA, J. T.; DA COSTA-SILVA, T. A.; BORBOREMA, S. E. T.; TEMPONE, A. G. Activity of imidazole compounds on Leishmania (L.) infantum chagasi: Reactive oxygen species induced by econazole. Mol. Cell. Biochem., v.389, p.293-300, 2014.

33. SANTOS, D. O. et al. Leishmaniasis treatment - A challenge that remains: A review. Parasitol. Res., v.103, p.1-10, 2008.

34. PONTIN, K. et al. In vitro and in vivo antileishmanial activities of a Brazilian green propolis extract. Parasitol. Res., v.103, p.487-492, 2008.

35. DOS SANTOS, V. A F. F. M. et al. Antiprotozoal activity of quinonemethide triterpenes from Maytenus ilicifolia (Celastraceae). Molecules, v.18, p.1053-1062, 2013.

36. OLIVEIRA, G. et al. Flebotomíneos (diptera: Psychodidae:Phlebotominae) no município de Três Lagoas, área de transmissão intensa de leishmaniose visceral, Estado de Mato Grosso do Sul, Brasil. Rev. Pan-Amazônica Saúde, v.1, p.83-94, 2010.

37. MURRAY, H. W.; BERMAN, J. D.; DAVIES, C. R.; SARAVIA, N. G. Advances in leishmaniasis. Lancet, v.366, p.1561-1577, 2005.

38. CASTILLO, D.; SAUVAIN, M.; RIVAUD, M. J. V. In Vitro and In Vivo Activity of Benzo [ c ] phenanthridines against Leishmania amazonensis. Planta Med., v.80, p.902-906, 2014.

39. GRIMALDI, G.; TESH, R. B. Leishmaniases of the New World : Current Concepts and Implications for Future Research. Clin. Microbiol. Rev., v.6, p.230-250, 1993.

40. BAILY, G.G;NANDY, A. Visceral leishmaniasis : more prevalent and more problematic. J. Infect., v.29, p.241-247, 1994.

41. HERWALDT, B. L. Leishmaniasis. Lancet, v.354, p.1191-1199, 1999.

42. ASHFORD, R. W. The leishmaniases as emerging and reemerging zoonoses. Int. J. Parasitol., v.30, p.1269-1281, 2000.

43. REITHINGER, R. et al. Cutaneous leishmaniasis. Lancet, v.7, p.581-596, 2007.

44. DAVIDSON, R. N. Leishmaniasis. Protozoal Trop. Infect., v.33, p.43-46, 2005.

45. DE SOUZA, G. F. P. et al. Leishmanicidal activity of primary S-nitrosothiols against Leishmania major and Leishmania amazonensis: implications for the treatment of cutaneous leishmaniasis. Nitric oxide, v.15, p.209-216, 2006.

46. MINODIER, P.; PAROLA, P. Cutaneous leishmaniasis treatment. Travel Med. Infect. Dis., v.5, p.150-158, 2007.

47. THALHOFER, C. J.; CHEN, Y.; SUDAN, B.; LOVE-HOMAN, L.; WILSON, M. E. Leukocytes infiltrate the skin and draining lymph nodes in response to the protozoan leishmania infantum chagasi. Infect. Immun., v.79, p.108-117, 2011.

48. MOORE, T. A. Visceral leishmaniasis. N. Engl. J. Med., v.25, p.535-551, 1997. 
49. CROFT, S. L.; COOMBS, G. H. Leishmaniasis - current chemotherapy and recent advances in the search for novel drugs. Trends Parasitol., v.19, p.502-508, 2003.

50. CROFT, S. L. Monitoring drug resistance in leishmaniasis. Trop. Med. Int. Heal., v.6, p.899-905, 2001.

51. FREITAS-JUNIOR, L. H.; CHATELAIN, E.; ANDRADE, H.; SIQUEIRA-NETO, J. L. Visceral leishmaniasis treatment: What do we have, what do we need and how to deliver it ? Int. J. Parasitol. Drugs Drug Resist., v.2, p.11-19, 2012.

52. CROFT, S. L.; BARRETT, M. P.; URBINA, J. A. Chemotherapy of trypanosomiases and leishmaniasis. Trends Parasitol., v.21, p.508-512, 2005.

53. CROFT, S. L.; SUNDAR, S.; FAIRLAMB, A. H. Drug Resistance in Leishmaniasis. Clin. Microbiol. Rev., v.19, p.111-126, 2006.

54. LOMBARDINO, J. G.; LOWE, J. A. The role of the medicinal chemist in drug discovery--then and now. Nat. Rev. Drug Discov., v.3, p.853-862, 2004.

55. ZHAO, H.; GUO, Z. Medicinal chemistry strategies in follow-on drug discovery. Drug Discov. Today, v.14, p.516-522, 2009.

56. LIRUSSI, D. et al. Inhibition of Trypanosoma cruzi by plant extracts used in Chinese medicine. Fitoterapia, v.75, p.718-723, 2004.

57. MOTTRAM, J. C.; COOMBS, G. H.; ALEXANDER, J. Cysteine peptidases as virulence factors of Leishmania. Curr. Opin. Microbiol., v.7, p.375-381, 2004.

58. MOTTRAM, J. C.; BROOKS, D. R.; COOMBS, G. H. Roles of cysteine proteinases of trypanosomes and Leishmania in host-parasite interactions. Curr. Opin. Microbiol., v.1, p.455-460, 1998.

59. SAJID, M. ; MCKERROW, J. H. Cysteine proteases of parasitic organisms. Mol. Biochem. Parasitol., v.120, p.1-21, 2002.

60. APARICIO, I. M.; SCHARFSTEIN, J., A, A. P. C.; LIMA, A. P. C. A. A New Cruzipain-Mediated Pathway of Human Cell Invasion by Trypanosoma cruzi Requires Trypomastigote Membranes. Infect. Immun., v.72, p.5892-5902, 2004.

61. MICHELS, P. A M.; AVILÁN, L. The NAD + metabolism of Leishmania, notably the enzyme nicotinamidase involved in NAD + salvage, offers prospects for development of anti-parasite chemotherapy. Mol. Microbiol., v.82, p.4-8, 2011.

62. MCKERROW, J. H.; SUN, E.; ROSENTHAL, P. J.; BOUVIER, J. THE PROTEASES AND PAHOGENICITY OF PARASITIC PROTOZOA. Annu. Rev. Microbiol., v.47, p.821-853, 1993.

63. DOYLE, P. S. et al. The trypanosoma cruzi protease cruzain mediates immune evasion. PLoS Pathog., v.7, p.1-11, v.(2011).

64. MCKERROW, J. H.; ENGEL, J. C.; CAFFREY, C. R. Cysteine protease inhibitors as chemotherapy for parasitic infections. Bioorg. Med. Chem., v.7, p.639-644, 1999. 
65. GONZALEZ, J.; BAI, G.; FREVERT, U.; COREY, E. J.; EICHINGER, D. Proteasome-dependent cyst formation and stage-specific ubiquitin mRNA accumulation in Entamoeba invadens. Eur. J. Biochem., v.264, p.897-904, 1999.

66. YOKOYAMA-YASUNAKA, J. K. U.; PRAL, E. M. F.; OLIVEIRA, O. C.; ALFIERI, S. C.; STOLF, A. M. S. Trypanosoma cruzi: Identification of proteinases in shed components of trypomastigote forms. Acta Trop., v.57, p.307-315, 1994.

67. BERASAIN, P.; CARMONA, C.; FRANGIONE, B.; CAZZULO, J. J.; GOÑI, F. Specific cleavage sites on human IgG subclasses by cruzipain, the major cysteine proteinase from Trypanosoma cruzi. Mol. Biochem. Parasitol., v.130, p.23-29, 2003.

68. DEL NERY, E.; JULIANO, M. A.; LIMA, A. P. C. A.; SCHARFSTEIN, J.; JULIANO, L. Kininogenase activity by the major cysteinyl proteinase (cruzipain) from Trypanosoma cruzi. J. Biol. Chem., v.272, p.25713-25718, 1997.

69. SCHARFSTEIN, J. et al. Host cell invasion by Trypanosoma cruzi is potentiated by activation of bradykinin B(2) receptors. J. Exp. Med., v.192, p.1289-1300, 2000.

70. BART, G.; COOMBS, G. H.; MOTTRAM, J. C. Isolation of Imcpc, a gene encoding a Leishmania mexicana cathepsin-B- like cysteine proteinase. Mol. Biochem. Parasitol., v.73, p.271-274, 1995.

71. ILG, T. et al. Distribution of parasite cysteine proteinases in lesions of mice infected with Leishmania mexicana amastigotes. Mol. Biochem. Parasitol., v.67, p.193-203, 1994.

72. SOARES, M. J.; SOUTO-PADRÓN, T.; DE SOUZA, W. Identification of a large pre-lysosomal compartment in the pathogenic protozoon Trypanosoma cruzi. J. Cell Sci., v.102, p.157-167; 1992.

73. ANNOURA, T.; NARA, T.; MAKIUCHI, T.; HASHIMOTO, T.; AOKI, T. The origin of dihydroorotate dehydrogenase genes of kinetoplastids, with special reference to their biological significance and adaptation to anaerobic, parasitic conditions. J. Mol. Evol., v.60, p.113-127, 2005.

74. NAGY, M.; LACROUTE, F.; THOMAS, D. Divergent evolution of pyrimidine biosynthesis between anaerobic and aerobic yeasts. Proc. Natl. Acad. Sci. U. S. A., v.89, p.8966-8970 1992.

75. JONES, M. E. Pyrimidine nucleotide biosynthesis in animals: genes, enzymes, and regulation of UMP biosynthesis. Annu. Rev. Biochem., v.49, p.253-279, 1980.

76. NAGRADOVA, N. K. Study of the properties of phosphorylating D-glyceraldehyde-3-phosphate dehydrogenase. Biochem., v.66, p.1067-1076, 2001.

77. SHEN, Y.; SONG, S.; LIN, Z. Structures of D -glyceraldehyde-3-phosphate dehydrogenase complexed with coenzyme analogues. Acta Crystallogr., v.58, p.1287-1297, 2002.

78. SIROVER, M. A. New insights into an old protein: the functional diversity of mammalian glyceraldehyde-3-phosphate dehydrogenase. Biochim. Biophys. Acta, v.1432, p.159-184 1999.

79. SIROVER, M. A. New nuclear functions of the glycolytic protein, glyceraldehyde-3-phosphate dehydrogenase, in mammalian cells. J. Cell. Biochem., v.95, p.45-52, 2005. 
80. HANNAERT, V.; OPPERDOES, F. R.; MICHELS, P. A. M. Glycosomal glyceraldehyde-3-phosphate dehydrogenase of Trypanosoma brucei and Trypanosoma cruzi: expression in Escherichia coli, purification, and characterization of the enzymes. Protein expression and purification, v.6, p.244-250, 1995.

81. PAVÃO, F. et al. Structure of Trypanosoma cruzi glycosomal glyceraldehyde-3-phosphate dehydrogenase complexed with chalepin, a natural product inhibitor, at $1.95 \AA$ A resolution. FEBS Lett., v.520, p.13-17, 2002.

82. LADAME, S. et al. Crystal structure of Trypanosoma cruzi glyceraldehyde-3-phosphate dehydrogenase complexed with an analogue of 1,3-bisphospho-D-glyceric acid: Selective inhibition by structure-based design. Eur. J. Biochem., v.270, p.4574-4586, 2003.

83. CASTILHO, M. S. et al. Evidence for the two phosphate binding sites of an analogue of the thioacyl intermediate for the trypanosoma cruzi glyceraldehyde-3-phosphate dehydrogenasecatalyzed reaction, from its crystal structure. Biochemistry, v.42, p.7143-7151, 2003.

84. FREITAS, R. F. et al. Discovery of novel Trypanosoma cruzi glyceraldehyde-3-phosphate dehydrogenase inhibitors. Bioorganic Med. Chem., v.17, p.2476-2482, 2009.

85. HEPLER, J. R.; GILMAN, A G. G proteins. Trends Biochem. Sci., v.17, p.383-387, 1992.

86. NEER, E. J. Heterotrimeric G proteins: organizers of transmembrane signals. Cell , v.80, p.249257, 1995.

87. HANKS, S. K.; QUINN, A. M.; HUNTER, T. The Protein Kinase Family : Conserved Features and Deduced Phylogeny of the Catalytic Domains. Science., v.241, p.42-52, 1988.

88. SMITH, R. D.; WALKER, J. C. Plant Protein Phosphatases. Annu. Rev. Plant Physiol. Plant Mol. Biol., v.47, p.101-125, 1996.

89. SHCHEMELININ, I.; ŠEFC, L. ; NEČAS, E. Protein kinases, their function and implication in cancer and other diseases. Folia Biol. (Praha)., v.52, p.81-101, 2006.

90. SILVA, B. V, HORTA, B. A C., BICCA, R., ALENCASTRO, D. \& PINTO, A. C. Proteínas quinases: características estruturais e inibidores químicos. Química nova, v.32, p.453-462, 2009.

91. HANAHAN, D.; WEINBERG, R. A. The Hallmarks of Cancer. Cell, v.100, p.57-70, 2000.

92. BOURGUIGNON, S. C.; MELLO, C. B.; SANTOS, D. O.; GONZALEZ, M. S.; SOUTO-PADRON, T. Biological aspects of the Trypanosoma cruzi (Dm28c clone) intermediate form, between epimastigote and trypomastigote, obtained in modified liver infusion tryptose (LIT) medium. Acta Trop., v.98, p.103-109, 2006.

93. ELLIS, J. A.; FISH, W. R.; SILEGHEM, M.; MCODIMBA, F. A colorimetric assay for trypanosome viability and metabolic function. Vet. Parasitol., v.50, p.143-149, 1993.

94. ROEHM, N. W.; RODGERS, G. H.; HATFIELD, S. M.; GLASEBROOK, A. L. An improved colorimetric assay for cell proliferation and viability utilizing the tetrazolium salt XTT. J. Immunol. Methods, v.142, p.257-265, 1991. 
95. WANG, F.; CAO, L. ; HU, S. A rapid and accurate 3-(4,5-dimethyl thiazol-2-yl)-2,5-diphenyl tetrazolium bromide colorimetric assay for quantification of bacteriocins with nisin as an example. J. Zhejiang Univ. Sci. B, v.8, p.549-554, 2007.

96. WANG, S.; YU, H.; WICKLIFFE, J. K. Limitation of the MTT and XTT assays for measuring cell viability due to superoxide formation induced by nano-scale TiO 2. Toxicol. Vitr., v.25, p.21472151, 2011.

97. BEJAOUI, N.; LEMIEUX, P.; PAGÉ, M.; CINQ-MARS, B. Optimization of the tetrazolium-based colorimetric assay for the measurement of cell number and citotoxicity. Int. J. Immunopharmacol., v.10, p.785-793, 1988.

98. FALLON, A. M.; HELLESTAD, V. J. Standardization of a colorimetric method to quantify growth and metabolic activity of Wolbachia-infected mosquito cells. Vitr. Cell. Dev. Biol. - Anim., v.44, p.351-356, 2008.

99. KAIRO, S. K.; BEDWELL, J.; TYLER, P. C.; CARTER, A.; CORBEL, M. J. Development of a tetrazolium salt assay for rapid determination of viability of BCG vaccines. Vaccine, v.17, p.2423-2428, 1999.

100. ZILBERG, D.; SINAI, T. Optimization and validation of a colorimetric assay for Tetrahymena sp. survival. Res. Microbiol., v.157, p.355-359, 2006.

101. DAMATTA, R. A. et al. Trypanosoma cruzi exposes phosphatidylserine as an evasion mechanism. FEMS Microbiol. Lett. 266, 29-33 (2007).

102. VERMEERSCH, M. et al. In Vitro Susceptibilities of Leishmania donovani Promastigote and Amastigote Stages to Antileishmanial Reference Drugs: Practical Relevance of Stage-Specific Differences. Antimicrob. Agents Chemother. 53, 3855-3859 (2009).

103. BLACK, C.; BEAULIEU, C. Cathepsin cysteine protrease inhibitors for the treatment of various diseases. 1-58 (2010).

104. BARQUILLA, A., CRESPO, J. L. \& NAVARRO, M. Rapamycin inhibits trypanosome cell growth by preventing TOR complex 2 formation. Proc. Natl. Acad. Sci. U. S. A. 105, 14579-14584 (2008).

105. MACHADO, M. et al. Activity of Thymus capitellatus volatile extract, 1,8-cineole and borneol against Leishmania species. Vet. Parasitol., v.200, p.39-49, 2014. 